\title{
4. SITES 389 AND 390: NORTH RIM OF BLAKE NOSE
}

\author{
Shipboard Scientific Party ${ }^{1}$
}

\section{SITE 389}

Dates Occupied: $28-29$ August 1975

Position: $30^{\circ} 08.54^{\prime} \mathrm{N} ; 76^{\circ} 05.57^{\prime} \mathrm{W}$

Water Depth: 2714 meters (corrected PDR), 2720 meters (drill pipe)

Penetration: See "Principal Results"

Number of Holes: 1

Number of Cores: 1

Total Length of Cored Section: See "Principal Results"

Total Core Recovered: 3.5 meters

Percentage Core Recovered: 37 per cent

Oldest Sediment Cored: Surface Holocene sand, shells, and manganese nodules

Basement: Not reached

Principal Results: An abortive attempt to spud in technically constitutes Site 389. Here we recovered a single core containing manganese nodules, sand, foraminifers, and shell fragments. Although the pipe we supposedly washed in 30.5 meters before attempting to take the first core, the bit apparently skidded across a surface patch of hard lag gravel and scooped about 3.5 meters of surface sediment into the core barrel. The bumper sub was bent as the bit deflected across the hard surface and drilling at the site was abandoned.

\section{SITE 390}

Dates Occupied: 29 August-1 September 1977

Position: $30^{\circ} 08.54^{\prime} \mathrm{N}$; $76^{\circ} 06.74^{\prime} \mathrm{W}$

Water Depth: 2665 meters (corrected PDR), 2656.5 meters (drill pipe)

Penetration: 206 meters

Number of Holes: 2

Number of Cores: 24

Total Length of Cored Section: 225 meters

Total Core Recovered: 114 meters

Percentage Core Recovered: 50.6 per cent

Oldest Sediment Cored: Barremian or older white limestone, at 206 meters sub-bottom

Basement: Not reached

Principal Results: We successfully drilled two holes at Site 390 following an abortive attempt to spud in at Site 389. In Hole 390 we recovered the first core at $\mathbf{1 2 3 . 5}$ meters sub-bottom and abandoned the hole when Barremian (or possibly older) soft, crumbly, limestone clogged the bit at 206 meters. We drilled

${ }^{1}$ William E. Benson and Robert E. Sheridan, Chief Scientists; Paul Enos, Tom Freeman, Felix M. Gradstein, Ivar O. Murdmaa, Léo Pastouret, Ronald R. Schmidt, Daniel H. Stuermer, Fred M. Weaver, Paula Worstell.
Hole 390A to sample the upper 123.5 meters which we had not cored in Hole 390.

Continuous coring through Eocene, Paleocene, and Maestrichtian sediments provided an outstanding stratigraphic sequence and offers an unusually good opportunity to study the biostratigraphic zonation in a sequence neither diluted by terrigenous sediments nor disturbed by bottom currents. We obtained an excellent biostratigraphic record, especially of the middle and lower Eocene which contains a triple assemblage of radiolarians, foraminifers, and nannofossils allowing their inter-comparison.

We identified two prominent seismic reflectors which correspond to: (1) lower Eocene and upper Paleocene cherty limestone and (2) a major hiatus between Campanian and Albian nannofossil ooze. To the west of the site, the hiatus forms a major angular unconformity below which at least three regional reflectors are truncated. At Site 390 the unconformity represents about a 30-m.y. hiatus (Campanian and Albian) and represents progressively less time toward the west. Santonian through Cenomanian sediments may be truncated by the unconformity.

The contact between shallow-water Barremian limestone and pelagic Aptian-Albian nannofossil ooze was cored in Hole 390. Although the transition zone is very narrow in the cored sediment, it represents an increase in water depth (estimated from fossil evidence), of from less than 100 meters to more than 500 meters (about $7 \mathrm{~cm} / 1000 \mathrm{yr}$ ). Although high, this rate is not unusual for the Early Cretaceous in the Blake-Bahama area.

Seismic reflection profiles trace both the Barremian limestone and the overlying ooze to an apparent reef structure (a 3 -km-wide rough, hyperbolic reflector) on the southeast rim of the Blake Nose. Submarine bottom currents apparently eroded the area during the Santonian (?) to produce the Campanian-Albian hiatus. The related change in environment may have helped end reef building on the Blake Nose.

\section{BACKGROUND, OBJECTIVES, AND STRATEGY}

\section{Background}

Sites 389 and 390 are just 1200 meters apart on the Blake Nose, a distinctive northeast-jutting spur of the Blake Plateau (Figures 1 and 2). The site was selected to provide new information on the Atlantic portion of a Cretaceous reef complex.

Cretaceous reefs and related structures form a chain that circles the Gulf of Mexico, extends through Cuba and the Bahamas, and rims the escarpment of the Blake Plateau (Figure 3, after Paulus, 1972; and Meyerhoff and Hatten, 1974). Seismic reflection data have suggested that the reef and bank-rim complex extend from Cape Hatteras to off the coast of New Jersey and along the edge of the Georges Bank (Sheridan, 1974; Schlee et al., 1976). In Mexico the Cretaceous reef complex rims petroleum-bearing limestone platforms (Golden Lane Atoll, Enos, 1974); in Texas and Louisiana it forms a zone of stratigraphic traps (Edwards Limestone or "Stuart City" reef). 


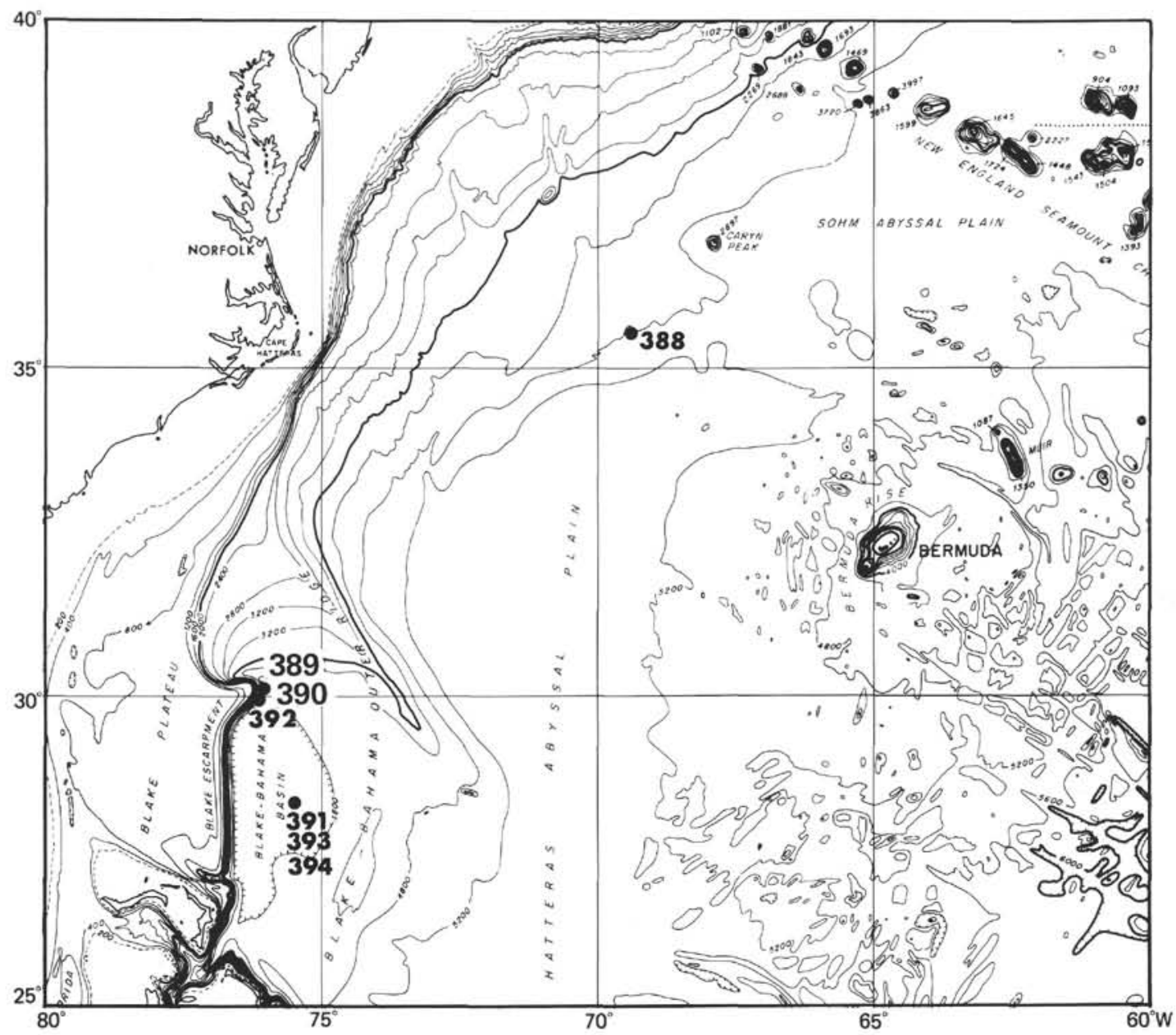

Figure 1. Map showing location of Sites 389 and 390 relative to the Atlantic margin.

Despite its economic importance in the Gulf area, the age and structure of the Cretaceous reef complex along the Atlantic continental margin are poorly known and we have little evidence of when the reef complex ceased to build and subsequently sank. Piston core and dredging data along the Blake Escarpment indicate that a complex reef-lagoon facies existed from at least Neocomian to Cenomanian or Campanian time (Heezen and Sheridan, 1966; Sheridan et al., 1971) (Figure 4).

Situated on the Blake Nose, Sites 389 and 390 offered an opportunity to penetrate the reef-bank complex in an area where we could safely drill: no apparent closure in either the supposed reef complex or the overlying sediments and where any potential accumulation of hydrocarbons would already have been flushed out by seawater along the edge of the escarpment (Meyerhoff and Hatten, 1974).

\section{Objectives}

Our specific objectives in drilling Site 389 were to: (1) drill through and sample the Tertiary section, noting especially any prominent hiatuses, (2) determine the nature of prominent reflecting horizons in the Tertiary section, (3) sample the supposed reef bank carbonate below a distinctive rough reflector and determine the latest age of reef-bank development, and (4) determine, if possible, why the reef-bank complex ceased to grow and conditions changed to pelagic sedimentation by early Tertiary time.

\section{Strategy}

The position of Site 389 was selected on the basis of Vema profile 26 , which shows the "reef reflector" at about 300 meters $(0.3 \mathrm{sec})$ sub-bottom, overlain by a prominent easterly dipping reflector at about $0.10 \mathrm{sec}$. (Figure 5). These reflectors are continuations of reflectors 1 and 4 of Ewing et al. (1966) to the west on the Blake Plateau. We planned to survey the site with a north-south reflection profile to confirm that no closure existed and to locate the drill site in several hundred meters of soft Tertiary sediments back from the steep edge of the Blake Escarpment. We were then to continuously core these sediments down to the upper part of the Cretaceous reef-bank complex.

\section{OPERATIONS}

\section{Site 398}

After leaving Site 388 at 0330 hours, ${ }^{2} 26$ August 1975, Glomar Challenger steamed south southeast for a little more than two days to the Blake Nose. Because we had only about

${ }^{2}$ Time is given in the text as local time. 


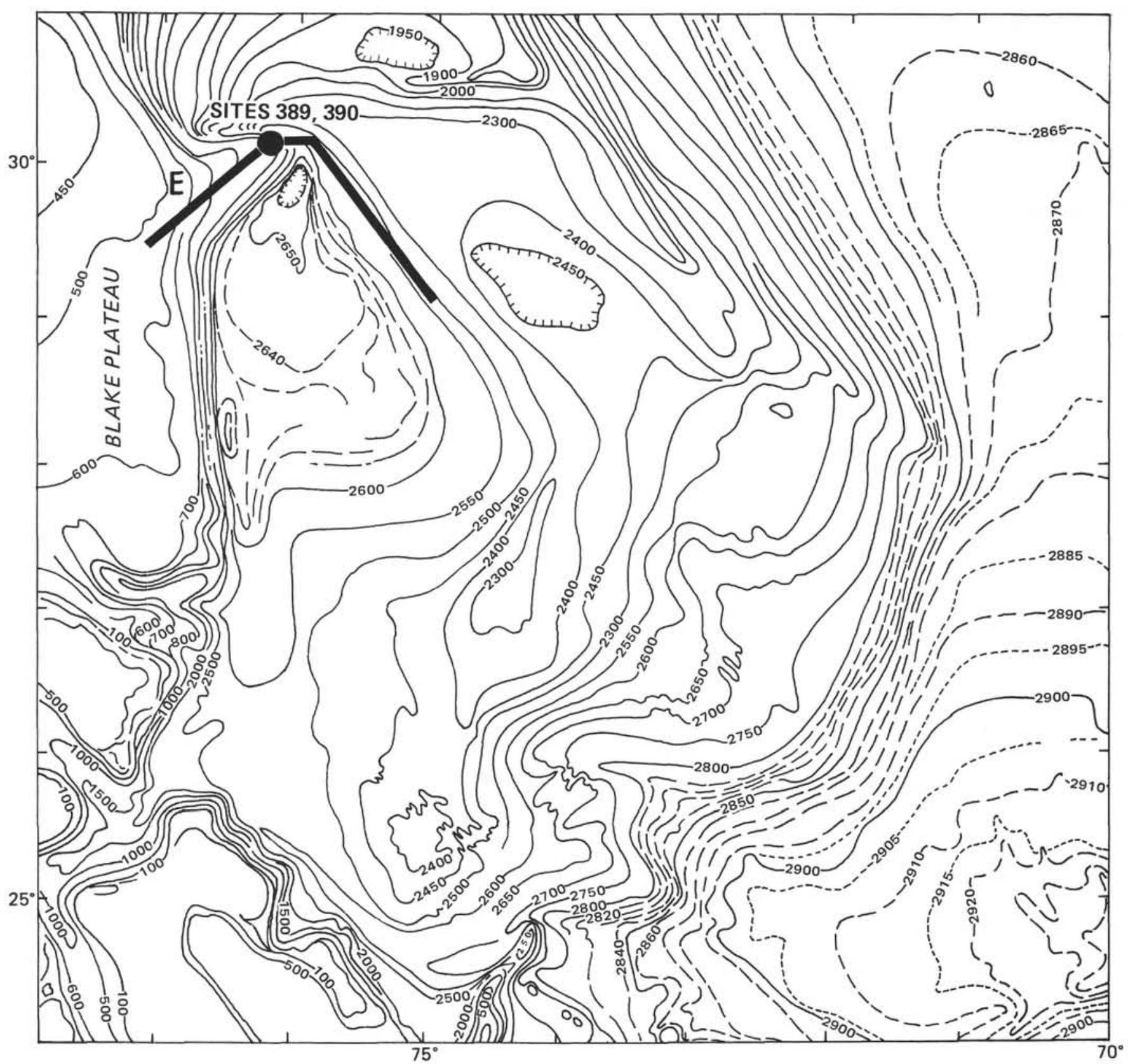

Figure 2. Detailed bathymetry in the vicinity of Sites 389 and 390. Depths in fathoms are on basis of computations of E. Schneider (personal communication). Profile along track $E$ is shown in Figure 5.

4800 meters of sand line aboard (see Site 388 Report), we chose to drill the comparatively shallow Blake Nose site (Site 389) while awaiting delivery from Jacksonville, Florida, of a new sand line.

The JOIDES Safety and Pollution Panel required us to complete an extensive seismic survey to guard against the possibility of drilling on structural closure in the beds above the supposed reef. The survey began at 0554 hours on 28 August. We crossed the nose from north to south, then re-crossed our track west to east (Figure 6). The north to south profile (Figure 7) showed a generally flat-lying or slightly synclinal structure in the deeper reflectors under the northern part of the Blake Nose (about 0650 hours), and we chose this area, shown on the west to east profile (Figure 8) as
Site 389. A pre-soaked $13.5-\mathrm{kHz}$ beacon was dropped underway at 1314 hours. On the final approach, however, we passed over a prominent angular unconformity at $0.20 \mathrm{sec}$ sub-bottom. Thus, in order to avoid drilling any possible pinch-out against the unconformity, we selected another site (i.e., dropped second beacon) farther east where the beds are horizontal or dip gently seaward.

After completing the site survey, Challenger returned to the beacon at 1455 hours and was in automatic positioning mode by 1514 hours. Water depth at Site 389 is 2714 meters corrected (1444 fm, uncorrected; $1484 \mathrm{fm}$, corrected). Currents were mild and from the northeast.

The pipe was run in at 1630 hours and by 0025 hours, 29 August the bit felt bottom at 2730 meters below the derrick 


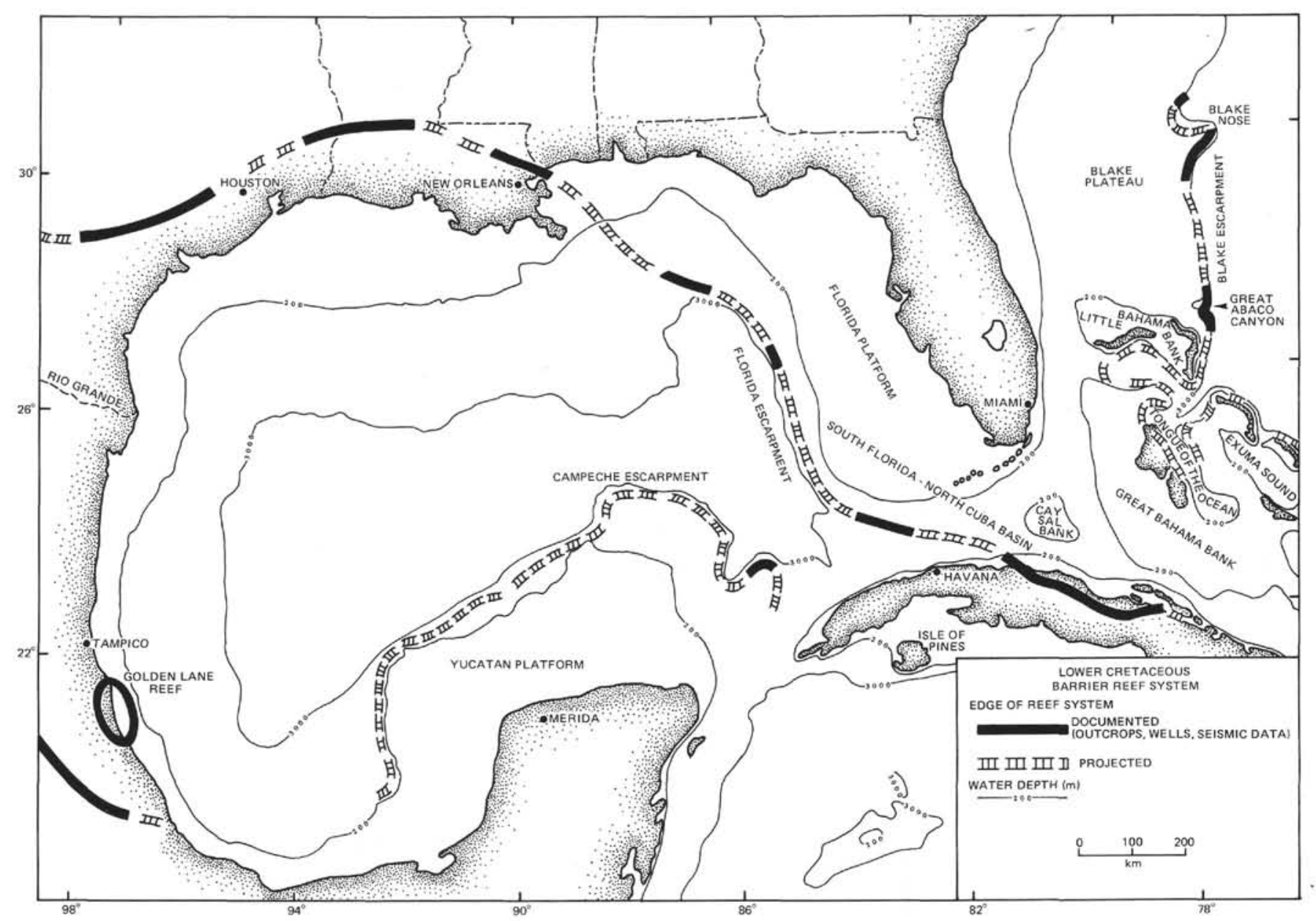

Figure 3. Distribution of Lower Cretaceous reef-complex rocks around the Gulf of Mexico, through Cuba, and the Bahamas to the Blake Nose (after Paulus, 1972).

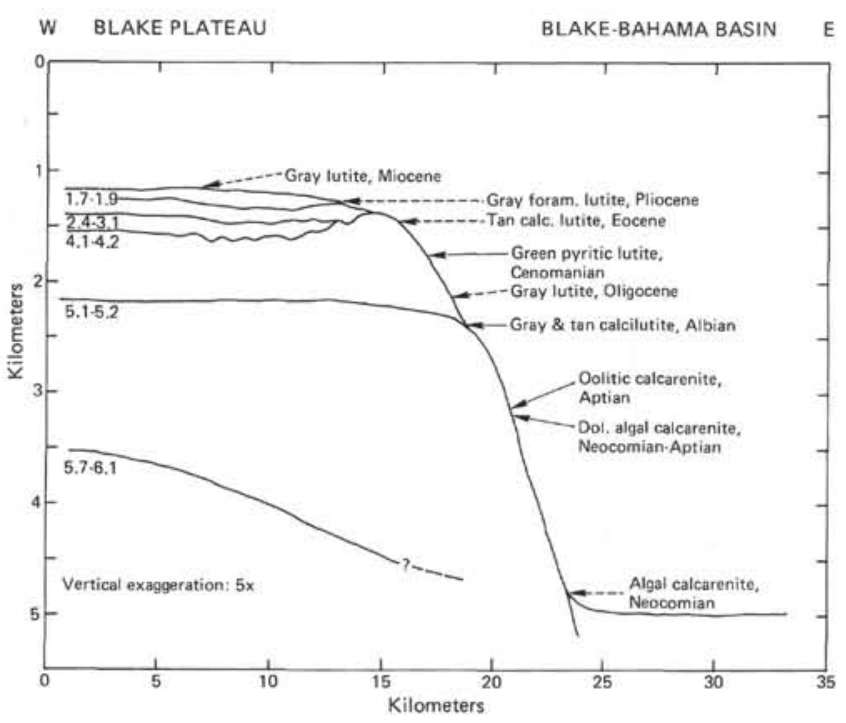

Figure 4. Summary of piston core (dashed arrows) and dredging (solid arrows) data from the Blake escarpment near Sites 389-390 (after Heezen and Sheridan, 1966). Velocities are in $\mathrm{km} / \mathrm{sec}$. floor. We cut a "mud-line" core but numerous attempts to retrieve it were futile. The pipe was difficult to rotate which suggested that the bumper sub was bent - a prediction later borne out when the bumper sub was retrieved. We began to pull pipe at 0410 hours and at 1135 hours the drill string was on deck. The middle bumper sub was bent in the "open" position to nearly $30^{\circ}$ (Figure 9). Although this can be caused by drag (movement of the ship while the pipe is in the hole), no significant deviation in ship position was recorded. The bent bumper sub was more likely caused by the bit being deflected by the hard "roller-bearing" surface of manganese nodules. The nature of the sediment from the single core collected at Site 398 (taken from the pipe after it was on deck) suggests this second alternative. The sediment consists of about 3.5 meters of coarse sand composed of hard manganese nodules, shell fragments, and fish teeth. The contents of the core was apparently scooped-up from the surface, washed, and artificially graded. Evidently a lag gravel - perhaps a meter or less thick - covers the sea floor at this site. The distribution of the surface gravels and manganese nodule beds is known to be patchy in that area so we abandoned Site 389 at 1335 hours, 29 August, and moved 4000 feet $(0.75$ nautical miles) due west along the seismic profile (Figure 8) 

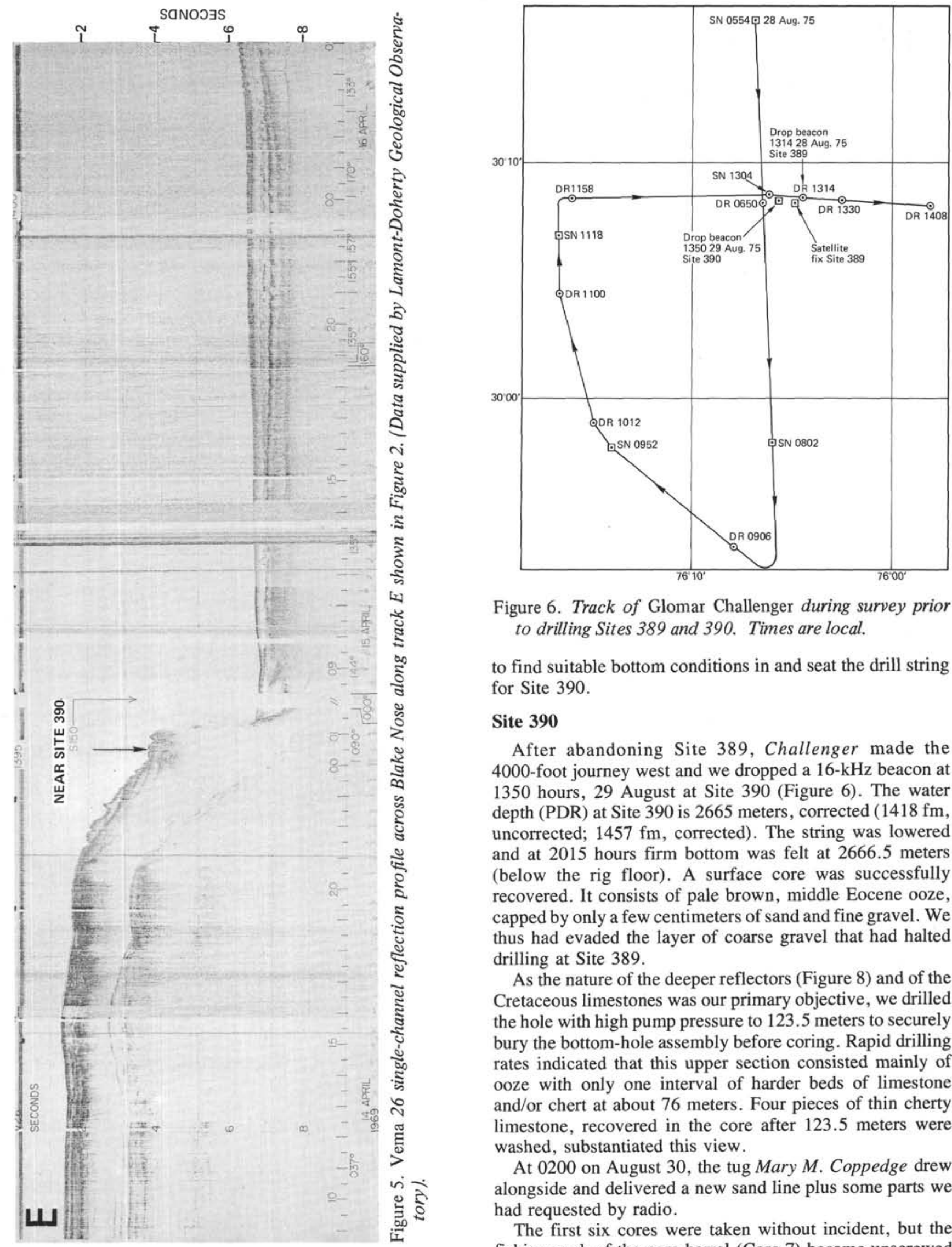

Figure 6. Track of Glomar Challenger during survey prior to drilling Sites 389 and 390. Times are local.

to find suitable bottom conditions in and seat the drill string for Site 390 .

\section{Site 390}

After abandoning Site 389, Challenger made the 4000 -foot journey west and we dropped a $16-\mathrm{kHz}$ beacon at 1350 hours, 29 August at Site 390 (Figure 6). The water depth (PDR) at Site 390 is 2665 meters, corrected (1418 fm, uncorrected; $1457 \mathrm{fm}$, corrected). The string was lowered and at 2015 hours firm bottom was felt at 2666.5 meters (below the rig floor). A surface core was successfully recovered. It consists of pale brown, middle Eocene ooze, capped by only a few centimeters of sand and fine gravel. We thus had evaded the layer of coarse gravel that had halted drilling at Site 389.

As the nature of the deeper reflectors (Figure 8) and of the Cretaceous limestones was our primary objective, we drilled the hole with high pump pressure to 123.5 meters to securely bury the bottom-hole assembly before coring. Rapid drilling rates indicated that this upper section consisted mainly of ooze with only one interval of harder beds of limestone and/or chert at about 76 meters. Four pieces of thin cherty limestone, recovered in the core after 123.5 meters were washed, substantiated this view.

At 0200 on August 30, the tug Mary M. Coppedge drew alongside and delivered a new sand line plus some parts we had requested by radio.

The first six cores were taken without incident, but the fishing neck of the core barrel (Core 7) became unscrewed 


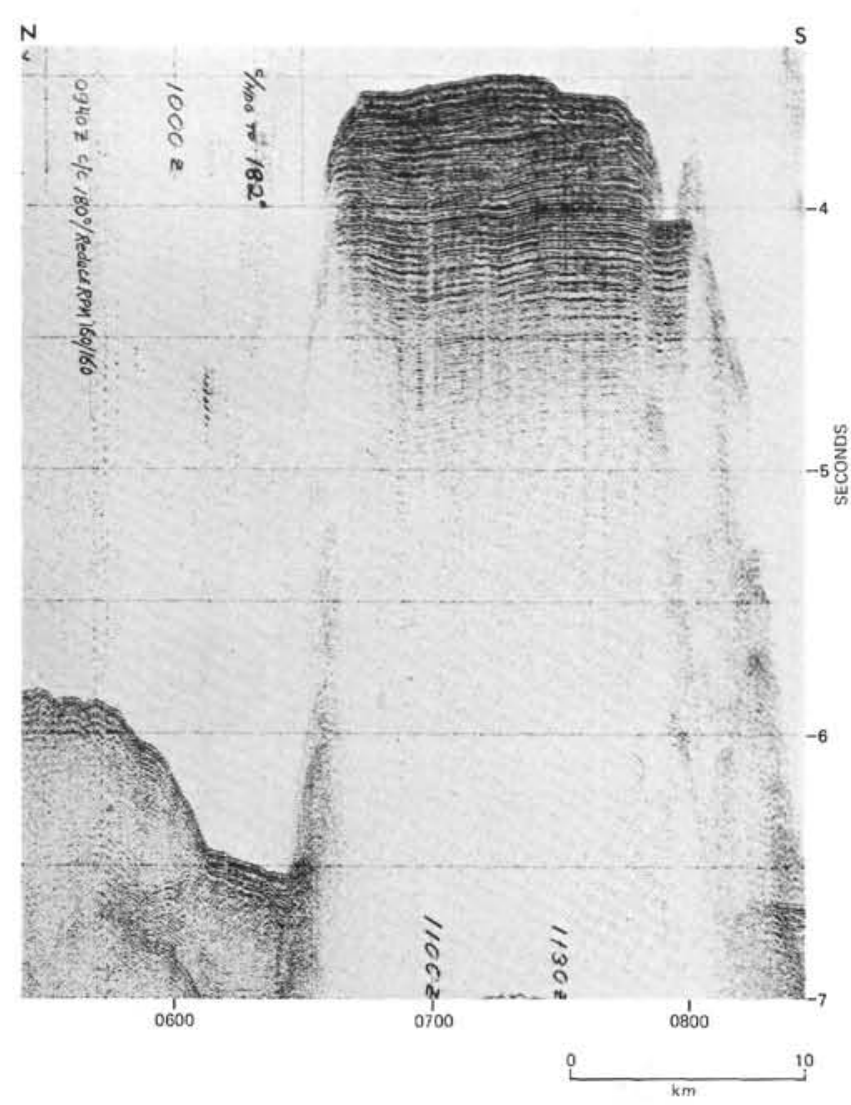

Figure 7. North-south seismic reflection profile made by Glomar Challenger during survey prior to drilling Site 389. Note flat-lying reflectors under Glake Nose. Local times are used.

and several " fishing"' attempts were made before Core 7 was brought on deck. At about 2000 hours during the run for Core 10 the bit became plugged and the pipe stuck. The pipe was eventually freed but circulation was never re-established. Following three unsuccessful tries to retrieve the stuck inner core barrel we decided to pull pipe and thus terminate the hole.

When retrieved, the inner core barrel was empty, but the annulus between inner and outer barrels was filled with finely ground white limestone, similar to that of Cores 8 and 9 . Although this limestone contained no fossils, we knew it was older than Barremian (Core 6), and thus decided not to attempt deeper penetration of what appeared to be an "'off-reef"' facies. Rather, we decided to core the upper part of the site. Ten cores were recovered from Hole 390 which was drilled to a depth of 206 meters.

Hole $390 \mathrm{~A}$ was spudded in on 31 August and was cored continuously to 142.5 meters; the final core was retrieved at 0645,1 September. Nine cores were recovered to a depth of 95 meters and the hole ended in lower Paleocene sediments.

Challenger left Site 390 on 1 September at 1600 hours. At 1620 , we re-crossed the site on a $265^{\circ}$ heading and dropped two sonobuoys. When both failed before meaningful results could be achieved, we changed course and steamed toward Site 391 in the Blake-Bahama Basin.

Drilling results of Sites 389 and 390 are given on Table 1.

\section{LITHOLOGY}

Drilling at Site 389 and 390 provided a continuous sedimentary record from the surface to a depth of 206 meters. We recovered only a single surface core, 3.5 meters long, at Site 389 before technical difficulties forced relocation at nearby Site 390 . The core resembles a graded bed; a gravel of manganese nodules and phosphorite clasts underlies and grades upward into manganiferous foraminifer sand and finally $5 \mathrm{~cm}$ of slightly muddy foraminifer sand at the top. This sequence is undoubtedly an artifact, resulting from partial suspension and gravity settling of materials within the core tube during recovery - after the fashion of a laboratory settling tube experiment.

We recovered 24 cores at Site 390 from Holes 390 and 390A. Drilling at Site 390 penetrated 206 meters of Quaternary to Barremian sediments comprising eight lithologic units. Middle Eocene to Barremian nannofossil oozes form six of the eight lithologic units. The oozes are capped by a Quaternary surface veneer and underlain by Lower Cretaceous or older limestone (Figure 10, Table 2).

\section{Unit 1}

Quaternary foraminifer sand and manganese nodules that veneer the surface comprise unit 1 . The single 3.5 -meter core from Site 389 (389-1) and the top $13 \mathrm{~cm}$ of Core $390-1$ fall in this unit.

In Core 389-1 a basal layer of gravel is $110 \mathrm{~cm}$ thick and consists of manganese nodules, pelecypod shells, phosphorite and limestone clasts, and shark teeth. (Remember that this core is artificially graded.) The matrix consists of planktonic foraminifer sand. Manganese nodules, the only abundant component of the gravel, are up to $5 \mathrm{~cm}$ in diameter, spherical or ellipsoidal, with a matt to lustrous surface and a smooth or botryoidal texture. Sections of nodules show poorly defined concentric layering, some spongy layers, and nuclei which appear to be claystone clasts less than $5 \mathrm{~mm}$ in diameter. The pelecypod shells are all flat and triangular with very flat hinge lines and linear ornamentation. All but a few are surficially stained a uniform shiny black which can be scraped off. Phosphorite clasts are light brown irregular plates up to $4 \mathrm{~cm}$ in maximum dimension. Some are encrusted by spirorbid worms. Limestone clasts are wackestone (65 per cent microcrystalline carbonate) of pelagic foraminifers. Except in the top few centimeters, the components of the gravel are scattered throughout the overlying sand, and decrease in size and frequency upward.

The sand consists of 86 per cent planktonic foraminifers with pteropods, heteropods, benthic gastropods, pelecypod shell fragments, echinoid spines, manganese fragments, quartz, glauconite pellets, and sponge spicules. The matrix mud at the top of the corè contains clay minerals, calcareous nannofossils, mica, and silt-sized dolomite rhombs. About 10 per cent of the foraminifer tests are completely coated by manganese; another 75 per cent are partially stained. Despite the pervasive staining, the overall sediment color is very pale brown (10YR 7/3) to olive (2.5Y 4/4).

At Hole 390 the manganiferous sediments include nodules up to $5 \mathrm{~cm}$ in diameter, black-coated thin-shelled 


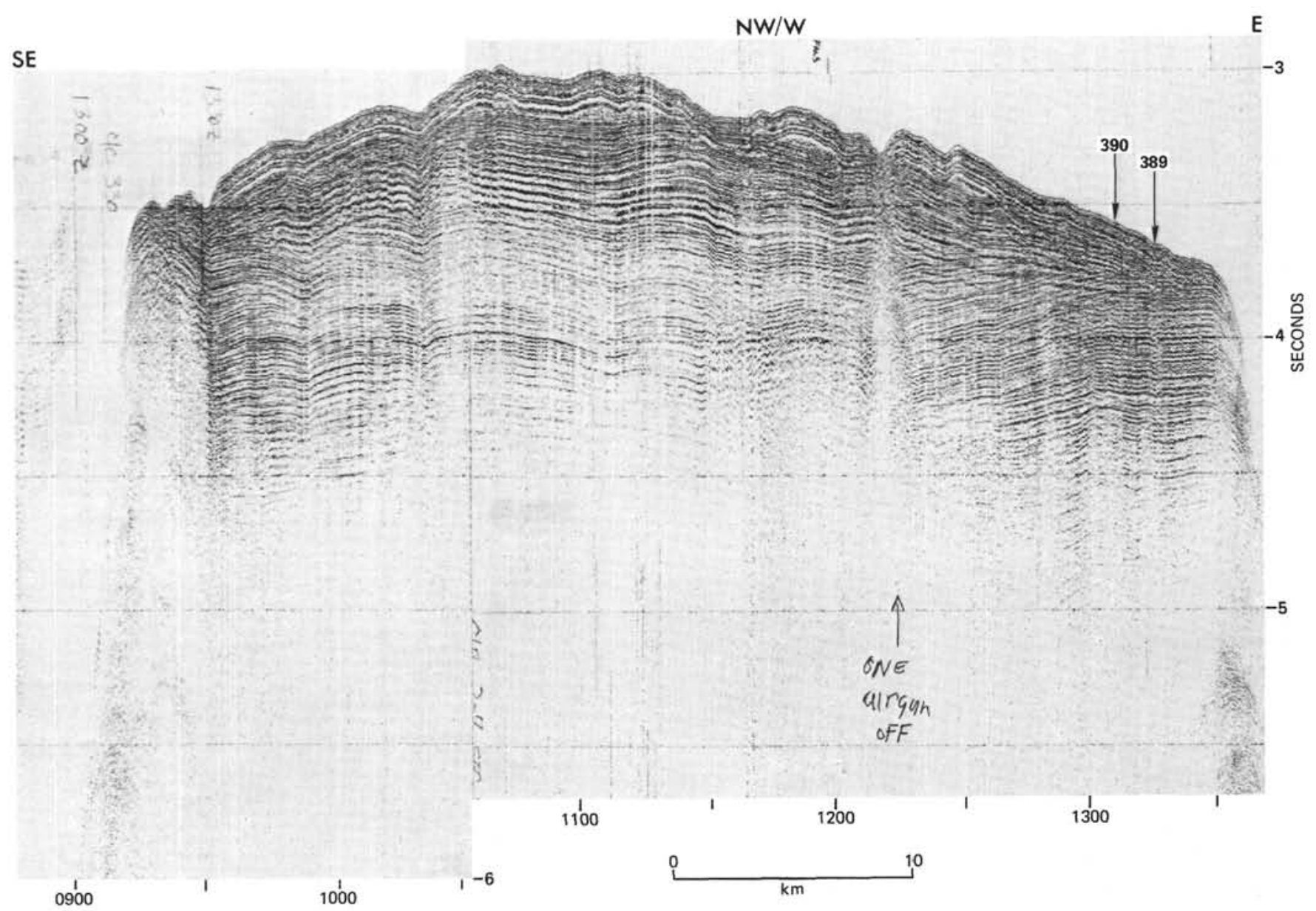

Figure 8. Seismic-reflection profile made by Glomar Challenger across Sites 389 and 390. Local time used.

pelecypods. About 10 per cent of the tests in the foraminiferal sand are completely coated. Although as much as 75 per cent of the foraminifers are partially stained, the overall sediment color is very light brown. Phosphorite clasts are present in the manganiferous gravel. The sand fraction consists of 86 per cent planktonic foraminifers, along with benthic gastropods, pteropods, echinoid spines, quartz, mica, dolomite rhombs, glauconite pellets, and fish teeth. Clay minerals and nannofossils occur in the sparse fine fraction. The foraminiferal fauna is "mixed," and both Pleistocene and Holocene forms are represented.

We do not know the true thickness of the layer cored. The disparity between 3.5 meters cored at Hole 389 and $13 \mathrm{~cm}$ cored at Hole 390A may reflect pockets of manganiferous sediment resting on an uneven substrate. But the greater thickness at Hole 389 was probably caused, in part, by "dredging" during an excursion of the bit across a gravelly surface. Dredging in such a fashion, however, probably would not skim a layer as thin as $13 \mathrm{~cm}$ without sampling the underlying layer.

Patches of manganese nodules are widely distributed on the Blake Plateau. This occurrence on the nose below the level of the main plateau surface probably results from in situ accumulation of manganese nodules by similar but poorly understood processes. Winnowing of finer particles by currents has concentrated the foraminifer sand and has resulted in very slow accumulation rates - an apparent prerequisite for manganese nodule accumulation. Currents probably play no appreciable role in transporting manganese nodules, even on a local scale, because of their size and density (e.g., relative to Globigerina). Thus the varying thickness of the surface layer is probably not a result of deposition by currents, although currents may contribute by eroding the soft substrate of nannofossil ooze thereby leaving depressions where nodules can accumulate.

\section{Unit 2}

White middle Eocene nannoplankton ooze comprises unit 2 (Figure 10); total thickness is estimated at 47 meters. Sediment colors include pale yellow (5Y 8/3, 5Y 8/4) and very pale brown (10YR $7 / 3,10$ YR $7 / 4)$, but white $(5 Y 8 / 2)$ is dominant. The ooze is about 80 per cent carbonate, predominantly nannofossils (Tables 3 and 4). Planktonic foraminifers are a minor $(6 \%)$, but persistent component (Figures 11, 12 and 13). A few benthic foraminifers were seen in Cores 3 and 4, Hole 390A. Siliceous skeletons, particularly sponge spicules and radiolarians (Figure 13), account for a third of the non-carbonate fraction (30\%). Zeolites average 6 per cent; they are more abundant in samples with little clay.

Subtle contrasts in color and shade suggest that the upper 8 meters of the unit were finely laminated before being disrupted by the drill bit. The consistency of the entire unit is about that of soft putty. No structures are visible in the lower 


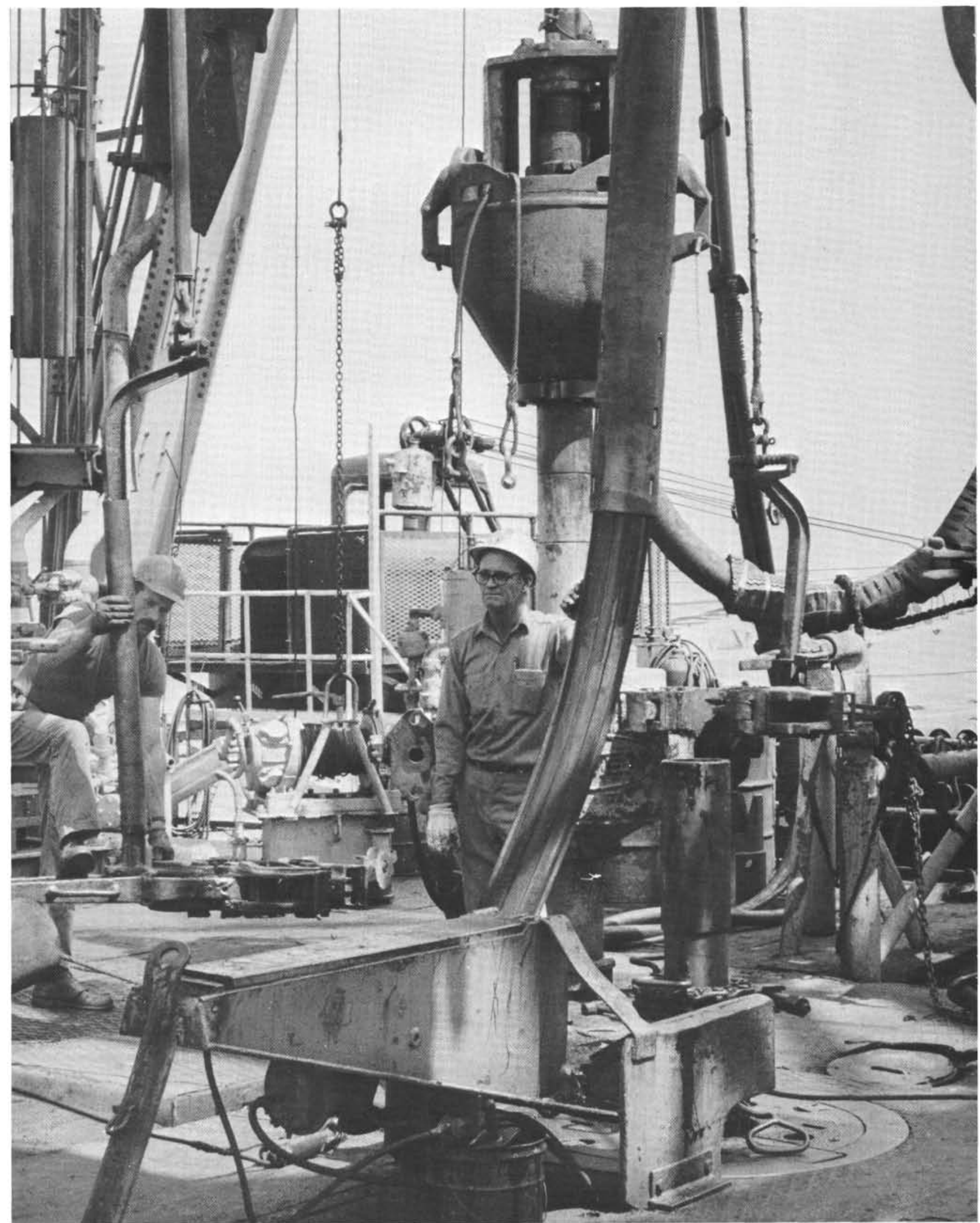

Figure 9. Bent bumper sub which caused us to abandon Site 389. Drilling supervisor A. C. Wheeler, Jr. registers his reaction. 
TABLE 1

Coring Summary, Site 389, 390

\begin{tabular}{|c|c|c|c|c|c|c|c|}
\hline \multirow{3}{*}{ Core } & \multicolumn{3}{|c|}{ Cored Interval } & \multirow{2}{*}{\multicolumn{2}{|c|}{ Recovered }} & \multirow{3}{*}{ Lithology } & \multirow{3}{*}{ Age } \\
\hline & Total Depth & Sub-Bottom & Cored & & & & \\
\hline & & Depth (m) & (m) & (m) & $(\%)$ & & \\
\hline \multicolumn{8}{|c|}{ Hole 389} \\
\hline 1 & $2760.0-2770.0$ & $30.5-39.5$ & 9.5 & 3.5 & 37 & Mn nodules, foraminifer sand & Quaternary \\
\hline Total & 277.0 & 39.5 & 9.5 & 3.5 & 37 & & \\
\hline \multicolumn{8}{|c|}{ Hole 390} \\
\hline 1 & $2666.5-2676.0$ & $0.0-9.5$ & 9.5 & 8.2 & 84 & Nannofossil ooze with foraminifer sand at top & Quaternary: middle Eocene \\
\hline Cutting & $2676.0-2790.0$ & $9.5-123.5$ & - & - & - & & \\
\hline 2 & $2790.0-2799.5$ & $123.5-133.0$ & 9.5 & 0.4 & 4 & Marly nannofossil ooze & Upper Maestrichtian \\
\hline 3 & $2799.5-2809.0$ & $133.0-142.5$ & 9.5 & 4.1 & 43 & Clay and marly nannofossil ooze & $\begin{array}{l}\text { Lower-middle Albian (and lower Maestrichtian } \\
\text { cavings) }\end{array}$ \\
\hline 4 & $2809.0-2818.5$ & $142.5-152.0$ & 9.5 & 2.2 & 23 & Marly nannofossil ooze and chalk & Lower-middle Albian \\
\hline 5 & 2818.5-2828.0 & $152.0-161.5$ & 9.5 & 2.4 & 25 & Marly nannofossil ooze and chalk & Upper Aptian; lower Aptian Barremian \\
\hline 6 & $2828.0-2837.5$ & $161.5-171.0$ & 9.5 & 0.6 & 7 & Calcareous chalk and ooze & Aptian-barremian \\
\hline 7 & $2837.5-2847.0$ & $171.0-180.5$ & 9.5 & 0.0 & 0 & - & \\
\hline 8 & $2847.0-2856.5$ & $180.5-190.0$ & 9.5 & 7.7 & 79 & Calcareous chalk, sand, and ooze & (Indeterminate) \\
\hline 9 & $2856.5 \cdot 2866.0$ & $190.0-199.5$ & 9.5 & 1.6 & 17 & Calcareous chalk and ooze & (Indeterminate) \\
\hline 10 & $2866.0-2872.5$ & $199.5-206.0$ & 6.5 & $<.1$ & 0 & Limestone & (Indeterminate) \\
\hline Total & 2872.5 & 206.0 & 91.9 & 27.2 & 30 & & \\
\hline \multicolumn{8}{|c|}{ Hole $390 \mathrm{~A}$} \\
\hline 1 & $2676.0-2685.5$ & $9.5-19.0$ & 9.5 & 1.2 & 13 & Calcareous ooze & Middle Eocene \\
\hline 2 & $2685.5-2695.0$ & $19.0-28.5$ & 9.5 & 2.3 & 24 & Siliceous nannofossil ooze & Middle Eocene \\
\hline 3 & $2695.0-2704.5$ & $28.5-38.0$ & 9.5 & 4.8 & 51 & Siliceous nannofossil ooze & Middle Eocene \\
\hline 4 & $2704.5-2714.0$ & $38.0-47.5$ & 9.5 & 9.5 & 100 & $\begin{array}{l}\text { Siliceous nannofossil ooze and nanno- } \\
\text { fossil chalk }\end{array}$ & Middle Eocene \\
\hline 5 & $2714.0-2723.5$ & $47.5-57.0$ & 9.5 & 4.1 & 43 & $\begin{array}{l}\text { Foram-nannofossil ooze, nannofossil } \\
\text { chalk and siliceous nannofossil ooze }\end{array}$ & Lower Eocene \\
\hline 6 & $2723.5-2733.0$ & $57.0-66.5$ & 9.5 & 9.5 & 100 & $\begin{array}{l}\text { Nannofossil ooze and siliceous nanno- } \\
\text { fossil ooze }\end{array}$ & Lower Eocene \\
\hline 7 & $2733.0-2742.5$ & $66.5-76.0$ & 9.5 & 5.3 & 56 & $\begin{array}{l}\text { Nannofossil ooze and siliceous nanno- } \\
\text { fossil ooze }\end{array}$ & Lower Eocene \\
\hline 8 & $2742.5-2752.0$ & $76.0-85.5$ & 9.5 & 4.9 & 52 & Nannofossil ooze and nannofossil chalk & Upper Paleocene \\
\hline 9 & $2752.0-2761.5$ & $85.5-95.0$ & 9.5 & 1.3 & 14 & Zeolitic nannofossil ooze & Lower Paleocene \\
\hline 10 & $2761.5 \cdot 2771.0$ & $95.0-104.5$ & 9.5 & 9.5 & 100 & Zeolitic marly nannofossil ooze & Lower Paleocene \\
\hline 11 & $2771.0-2780.5$ & $104.5-114.0$ & 9.5 & 7.8 & 82 & $\begin{array}{l}\text { Nannofossil ooze, marly nannofossil } \\
\text { ooze and calcareous clay }\end{array}$ & Lower Paleocene \\
\hline 12 & $2780.5-2790.0$ & $114.0-123.5$ & 9.5 & 9.5 & 100 & Nannofossil ooze & Upper Maestrichtian \\
\hline 13 & $2790.0-2799.5$ & $123.5-133.0$ & 9.5 & 9.5 & 100 & Nannofossil ooze & Upper Maestrichtian; lower Maestrichtian \\
\hline 14 & $2799.5-2809.0$ & $133.0-142.5$ & 9.5 & 7.6 & 80 & $\begin{array}{l}\text { Nannofossil ooze and marly nannofossil } \\
\text { ooze }\end{array}$ & $\begin{array}{l}\text { Lower Maestrichtian; upper Campanian; } \\
\text { lower-middle Albian }\end{array}$ \\
\hline Total & 2809.0 & 142.5 & 133.0 & 86.8 & 65 & & \\
\hline
\end{tabular}

part of unit 2, which is uniformly white. Carbonate contents in the lower part range from 70 to 76 per cent, compared with 80 to 90 per cent in the upper 8 meters (Figure 14). The decrease is partially caused by dilution through increased abundance of siliceous skeletons (Figures 11 and 13).

The upper boundary of unit 2 is essentially the sea floor except for the manganiferous veneer comprising unit 1 . Lithologies representative of units 2 and 3 are interbedded near the base of Core 390A-4 and the top of Core 390A-5, an interval totaling 2.0 to 7.4 meters. ${ }^{3}$ This gradational boundary is consistent with the biostratigraphic evidence of a conformable transition from middle to lower Eocene.

\section{Unit 3}

Unit 3 also consists of nannofossil ooze (about $45 \%$ recognizable nannofossils and $67 \%$ total carbonate), with a few layers of chalk and cherty limestone. It differs from unit 2 in that it includes lithified intervals, has an appreciably higher silica content (about 18\%) in the upper part, and by being slightly darker in color (very pale brown, 10YR 8/3, $8 / 4,7 / 3$; light yellowish brown, 10YR 6/4; and pale yellow,

\footnotetext{
${ }^{3}$ The uncertainty as to thickness derives from incomplete recovery in Core $390 \mathrm{~A}-5$. The mean value, $4.7 \mathrm{~m}$, is assumed.
}

$5 \mathrm{Y} 8 / 3$ ). Two subunits are recognized within unit 3 . The upper unit, 3a consists of 24 meters of siliceous nannofossil ooze ( $18 \%$ silica) with four lithified layers which comprise only 2 per cent of the recovered material. Unit $3 b$ is 19 meters thick and contains virtually no siliceous skeletons (Figure 13), but includes four chert beds among seven limestone layers. The rock layers comprise 18 per cent of the recovery.

The composition of the chalk and limestone is the same as the adjacent oozes, i.e., nannofossils, "unspecified carbonate" mud, and a few planktonic foraminifers. The cherts occur within lithifidd carbonate intervals. The irregular contacts between chert and limestone (Figure 15), and the occurrence of silicified calcareous fossils and ghosts of burrows within the chert all indicate the chert originated by replacement.

Sedimentary structures in the ooze were largely obliterated during coring, although a few wisps of contrasting colors in unit 3a suggest widely spaced layering. Simple burrows are visible in most of the lithified portions, suggesting that burrows may have been common throughout the interval before being disrupted by drilling. A faint complex burrow in Section 390A-5-2 at $57 \mathrm{~cm}$ resembles a horizontal Zoophycos.

The top of unit 3 is the interbedded zone described above. The contact between sub-units $3 \mathrm{a}$ and $3 \mathrm{~b}$ is the top of a 


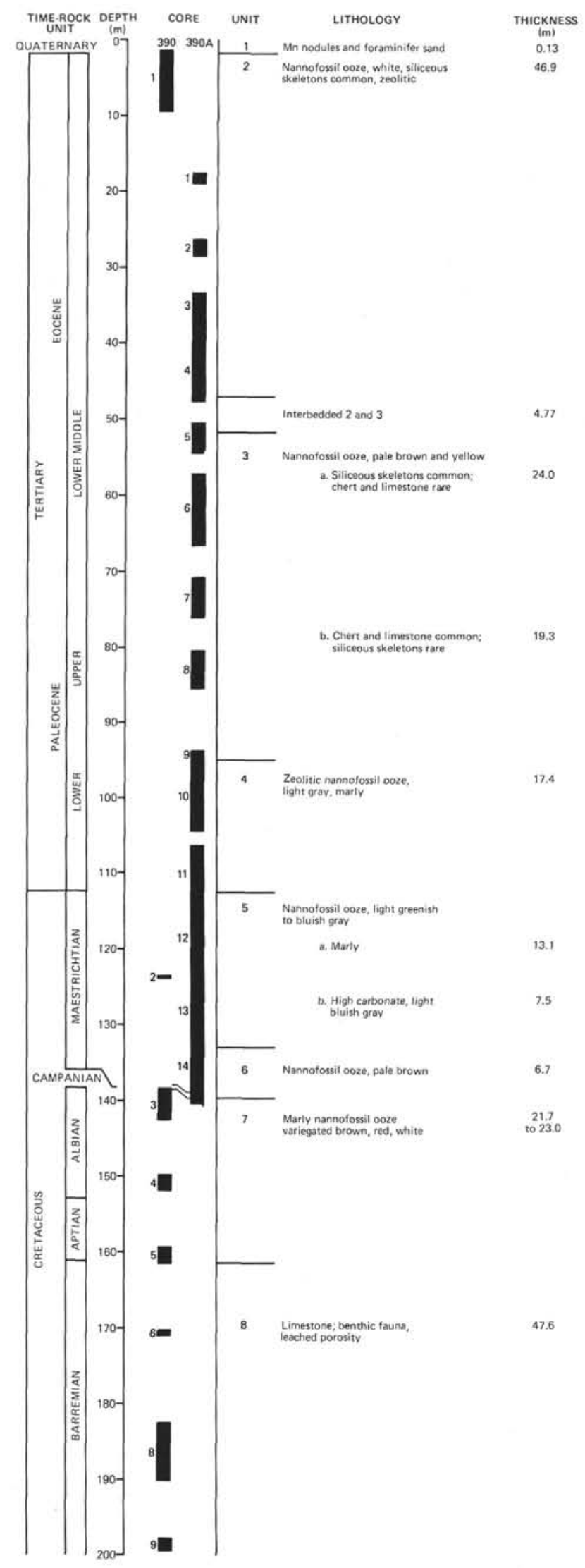

Figure 10. Graphic summary of lithologic units, Site 390. prominent chert-bearing lithified interval which probably marks a slight hiatus separating lower Eocene and upper Paleocene rocks. These rock layers form a prominent seismic reflector (see below). The base of unit 3 occurs between Cores $390 \mathrm{~A}-9$ and -10 ; the top of unit 4 is variegated ooze lacking lithified intervals.

\section{Unit 4}

Unit 4 is a 17.4-meter zeolitic nannofossil ooze. Zeolites total 9 per cent. Layers 5 to $10 \mathrm{~cm}$ thick in the upper 1.5 meters of unit 4 are marked by slightly contrasting shades of light brownish gray, light gray, and white (10YR $6 / 2,7 / 2$, and $8 / 2$, respectively). Burrows also produce mottles of these same colors. The remainder of unit 4 is mat white $(5 Y 7 / 2$, 10YR $8 / 2$ ), except for the basal 3 meters, which again have indistinct, highly distorted streaks of color including very pale brown (10YR 8/3), pink (5YR 7/3), pale greenish gray (5G 6/1), and pale blue green (5BG 7/2). The base of unit 4 is placed at a subtle but distinct change in color to very light gray. The color change coincides with a slight increase in carbonate content and "drier," more compact fabric. The base of unit 4 corresponds to the Cretaceous/Tertiary boundary.

\section{Unit 5}

Unit 5 is a 20.6-meter-thick Maestrichtian nannofossil ooze which is firmer or "drier" than the overlying units (see Physical Properties, this volume). Sub-unit 5a is 13.1 meters thick, contains 20 per cent clay minerals and 73 per cent carbonate (Table 3 ), and is light greenish gray $(5 \mathrm{G} 8 / 1,7 / 1)$ or light bluish gray (5B 7/1). It is well laminated in Core $390 \mathrm{~A}-12$. Sub-unit 5 b is slightly lighter bluish gray (5B $8 / 2)$, contains more carbonate $(89 \%)$, and lacks structures. The base of unit 5 occurs between Cores 390A-13 and -14 (also between 390-2 and - 3 where recovery was poor) with a color change from bluish gray to pale brown.

\section{Unit 6}

Unit 6 is a 6.7-meter Maestrichtian and upper Campanian, almost pure nannofossil ooze $\left(91 \% \mathrm{CaCO}_{3}\right.$, on the basis of carbon/carbonate analyses; $70 \%$ are recognizable nannofossils, seen in smear slides.) It is very pale brown (10YR 8/3) grading to off-white (10Y 8/1) near the base. Sedimentary structures are lacking, but bands of slightly firmer ooze, $5-10 \mathrm{~cm}$ thick, occur throughout more of the unit at an average spacing of about $25 \mathrm{~cm}$. These may be artifacts of drilling, but they apparently presage a marked increase in firmness at the top of the underlying unit. The lower boundary of unit yis primarily defined by a change to slightly marly variegated ooze near the base of Core 390A-14. This change coicides with a prominent reflector which denoes a local unconformity between Campanian and lower Albian sediments.

\section{Unit 7}

Distinctive variegated marly nannofossil oozes (average clay mineral content $46 \%$, Table 4 ) comprise unit 7 . The unit is 23 meters thick and includes lower Albian and Barremian-Aptian sediments. The sediment color includes many shades of reddish brown (5YR 4/4), red (2.5 YR 4/6), 
TABLE 2

Summary of Lithologic Units, Site 390

\begin{tabular}{|c|c|c|c|c|c|c|}
\hline Unit & Lithology & $\begin{array}{c}\text { Time-Rock } \\
\text { Unit }\end{array}$ & $\begin{array}{l}\text { Thickness } \\
\text { (m) }\end{array}$ & $\begin{array}{l}\text { Sub-Bottom } \\
\text { Depth of Top } \\
(\mathrm{m})\end{array}$ & $\begin{array}{l}\text { Recovery } \\
(\%)\end{array}$ & Cores \\
\hline 1 & $\begin{array}{l}\text { Manganese nodules and } \\
\text { foraminifer sand }\end{array}$ & Quaternary & 0.13 & 0 & 100 & $390-1,100-113 \mathrm{~cm}$ \\
\hline 2 & $\begin{array}{l}\text { Nannofossil ooze, white, } \\
\text { zeolitic, siliceous } \\
\text { skeletons common }\end{array}$ & Middle Eocene & 46.9 & 0.1 & 54 & $\begin{array}{l}390-1 \text {, below } 113 \mathrm{~cm} \\
390 \mathrm{~A}-1 \text { thru }-4 \text {, Sect. } 6\end{array}$ \\
\hline $2 / 3$ & Interbedded interval & & 4.7 & 47.0 & 42 & $390 \mathrm{~A}-4$, Sect. $6,100 \mathrm{~cm}$ thru -5 , Sect. 3 \\
\hline \multirow[t]{3}{*}{3} & $\begin{array}{l}\text { Nannofossil ooze, pale } \\
\text { brown and yellow }\end{array}$ & & 43.3 & 51.7 & 54 & \\
\hline & $\begin{array}{l}\text { 3a. Siliceous skeletons } \\
\text { common, chert and } \\
\text { limestone rare }\end{array}$ & Lower Eocene & $(24.0)$ & $(51.7)$ & (71) & $390 \mathrm{~A}-5$, to -7 , Sect. $4,130 \mathrm{~cm}$ \\
\hline & $\begin{array}{l}\text { 3b. Chert and limestone } \\
\text { common, siliceous } \\
\text { skeletons rare }\end{array}$ & Upper Paleocene & (19.3) & $(75.7)$ & (33) & $390 \mathrm{~A}-7$, Sect. 4 thru -9 \\
\hline 4 & $\begin{array}{l}\text { Zeolitic nannofossil } \\
\text { ooze, light gray, marly }\end{array}$ & Lower Paleocene & 17.4 & 95.0 & 93 & 390 A-10 thru -11 , Sect. 5 \\
\hline \multirow[t]{3}{*}{5} & $\begin{array}{l}\text { Nannofossil ooze, light } \\
\text { greenish and bluish gray }\end{array}$ & Maestrichtian & 20.6 & 112.4 & 100 & \\
\hline & 5a. Marly ( $20 \%$ clay) & & (13.1) & $(112.4)$ & & $\begin{array}{l}390-2 \\
390 \mathrm{~A}-11 \text {, Sect. } 6 \text { thru }-13 \text {, Sect. } 1\end{array}$ \\
\hline & $\begin{array}{l}5 \text { b. High carbonate, light } \\
\text { bluish gray }\end{array}$ & & (7.5) & (125.5) & & $390 \mathrm{~A}-13$, Sects. $2-6$ \\
\hline 6 & $\begin{array}{l}\text { Nannofossil ooze, pale } \\
\text { brown }\end{array}$ & $\begin{array}{l}\text { Maestrichtian, } \\
\text { Campanian }\end{array}$ & 6.7 & 133.0 & 100 & $390 \mathrm{~A}-14$, Sects. $1-5,80 \mathrm{~cm}$ \\
\hline 7 & $\begin{array}{l}\text { Marly nannofossil ooze, } \\
\text { variegated red, brown, } \\
\text { white }\end{array}$ & Aptian, Albian & $23.0-21.7$ & 139.7 & 37 & $\begin{array}{l}390 \mathrm{~A}-14 \text {, below Sect. } 5,80 \mathrm{~cm} \\
390-3 \text { thru }-5\end{array}$ \\
\hline 8 & $\begin{array}{l}\text { Limestone, benthic } \\
\text { fauna, leached porosity }\end{array}$ & $\begin{array}{l}\text { Barremian, and } \\
\text { Upper Aptian }\end{array}$ & 47.6 & 161.4 & 20 & $390-6$ thru -9 \\
\hline
\end{tabular}

and yellow ( $5 \mathrm{Y} 8 / 5)$ with lighter shades including pale brown (10YR 7/4), pink (5YR 7/3), pale yellow (5YR 8/3), white, light gray, and a few laminae of pale blue green (5BG 7/2) and greenish gray (5GY 6/1). Color is clearly related to clay content which is highest in red sediments, intermediate in sediments of lighter shades, and lowest in light gray and white sediments (Table 5). The color contrasts define a marked layering on a scale of a few centimeters, and, locally, millimeter laminations. Burrow mottling is common in reddish layers $(75 \%)$ but relatively rare in white and light layers $(15 \%)$.

\section{Unit 8}

Unit 8 consists largely of crystalline carbonate silt with isolated fragments of white and light gray limestone. It is in contact with the overlying unit in Core $390-5, \mathrm{CC}$. The silt is probably an artifact produced by drilling unconsolidated or chalky carbonates interlayered with hard limestone. We recovered sediments from a 47.6-meter interval $(20 \%$ recovery), but only descriptions of the limestone fragments, which we examined in reflected light and thin sections, are meaningful (Table 6). A variety of limestone is represented, but we recognize a few common denominators. (1) The organic remains, represented largely by molds, are, except for one ammonite, of benthic organisms. Planktonic fossils, which comprise practically all of the organic carbonate of the overlying units, are absent. (2) The non-skeletal particles (oolites, grapestone, pelletoids) are typical of shallow-water shelf environments. (3) Most of the porosity of these limestones derives from the solution of carbonate grains. (4) Lithification involved the precipitation of sparry calcite cement and the formation of neomorphic finely crystalline calcite ("recrystallization"). (5) There is no evidence of

TABLE 3

Average Calcium Carbonate Content for Lithologic Units and Sub-Units From LECO Determinations (app. 1)

\begin{tabular}{lcc}
\hline Unit & $\begin{array}{c}\text { Sub-Unit Average } \\
\left(\% \mathrm{CaCO}_{3}\right)\end{array}$ & $\begin{array}{c}\text { Unit Average } \\
\left(\% \mathrm{CaCO}_{3}\right)\end{array}$ \\
\hline 1 & & $78(1)$ \\
2 & & $70(13)$ \\
$3 \mathrm{a}$ & $68(8)$ & $67(10)$ \\
$3 \mathrm{~b}$ & $65(2)$ & $70 \%$ (bomb \\
4 & & average) \\
& & 78 \\
$5 \mathrm{a}$ & $74(8)$ & $91(3)$ \\
$5 \mathrm{~b}$ & $89(3)$ & $53(9)$ \\
7 & & $92(2)$ \\
\hline 8 & & \\
\hline
\end{tabular}


TABLE 4

Abundance (per cent) of Principal Constituents in the Eight Stratigraphic Units Cored at Holes 389, 390, and 390A

\begin{tabular}{lcccccccc}
\hline $\begin{array}{l}\text { Lithologic Unit } \\
\text { (no. of analysis) }\end{array}$ & $\begin{array}{c}1 \\
(3)\end{array}$ & $\begin{array}{c}2 \\
(25)\end{array}$ & $\begin{array}{c}3 \\
(19)\end{array}$ & $\begin{array}{c}4 \\
(15)\end{array}$ & $\begin{array}{c}5 \\
(18)\end{array}$ & $\begin{array}{c}6 \\
(3)\end{array}$ & $\begin{array}{c}7 \\
(18)\end{array}$ & $\begin{array}{c}8 \\
(8)\end{array}$ \\
\hline Quartz & 2 & & & 1 & 2 & & 1 & \\
& $(0-5)$ & & & $(0-5)$ & $(0-5)$ & & $(0-20)$ & \\
$\begin{array}{l}\text { Terrigenous } \\
\text { clay }\end{array}$ & & 7 & 19 & 20 & 14 & 8 & 46 & 5 \\
Zeolites & & $(0-30)$ & $(0-30)$ & $(0-70)$ & $(2-53)$ & $(0-15)$ & $(0-65)$ & $(0-5)$ \\
& & 6 & 2 & 9 & 0 & & 0 & \\
Carbonate & 3 & 11 & 17 & 14 & 14 & 23 & 22 & 93 \\
unspecified & $(1-5)$ & $(0-75)$ & $(0-75)$ & $(0-40)$ & $(0-50)$ & $(10-30)$ & $(0-85)$ & $(85-100)$ \\
Foraminifers & 86 & 6 & 5 & 2 & 3 & 0 & 0 & \\
& $(79-90)$ & $(1-20)$ & $(0-13)$ & $(0-6)$ & $(0-9)$ & $(0-1)$ & $(0-1)$ & \\
$\begin{array}{l}\text { Calcareous } \\
\text { nannofossils }\end{array}$ & 6 & 63 & 44 & 54 & 67 & 69 & 31 & 2 \\
$\begin{array}{l}\text { Siliceous } \\
\text { fossils }\end{array}$ & $(2-15)$ & $(19-85)$ & $(20-78)$ & $(10-82)$ & $(20-85)$ & $(55-90)$ & $(5-90)$ & $(0-15)$ \\
\hline
\end{tabular}

Note: Averages compiled from smear slide analyses. (Ranges of abundance shown in parentheses). Carbonate averages ("unspecified" and "calcareous nannofossils"), relative to those of terrigenous clay are adjusted with carbonate bomb data.

compaction such as stylolites, sutured grain contacts, or compressed grains.

Scattered limestone fragments persisted to the total depth of 206 meters. We obtained no biostratigraphic information from the limestone, but foraminifers and nannoplankton from a soft sediment associated with limestone fragments in 390-5, CC and 390-6, CC are Barremian.

\section{Lithologic and Biostratigraphic Boundaries}

Holes 390 and 390A, although not chosen primarily for biostratigraphic purposes, and despite the generally condensed nature of the section, have a surprisingly complete Upper Cretaceous and lower Tertiary succession. Recovery of contacts between lithologic units and sub-units was good, and the coincidence between lithologic boundaries and biostratigraphic boundaries gratifying (Table 7). Boundaries between major time units accompanied by at least slight hiatuses correspond to unit or sub-unit boundaries in five cases. The Maestrichtian/Campanian boundary occurs within unit 6 , but the Campanian is probably represented by only about $25 \mathrm{~cm}$ of very pale brown sediment (Core $390 \mathrm{~A}-14-5,55-78 \mathrm{~cm}$ ) underlying white nannofossil ooze at the base of unit 6 . We did not recover Campanian sediments or any sediment from unit 6 in Hole 390 (Figure 10).

\section{Depositional Environments}

\section{Barremian Limestones}

The Barremian and/or older limestones of unit 8 were clearly deposited in shallow water, probably in a shelf environment. Fossils are almost exclusively of benthic organisms - pelecypods, benthic gastropods, miliolid and other foraminifers, spirorbid worms, brachiopods(?), and green algae.

One ammonite was recovered, but we saw no planktonic fossils. The non-skeletal particles are generally indicative of shallow shelf conditions. Modern ooids are confined to very shallow waters - less than 50 meters and commonly in less than 5 meters water depths. "Grapestone" aggregates occur on shallow-water platforms, such as the Bahama Banks, at depths less than 20 meters where sediments accumulate relatively slowly. Pellets are not diagnostic inasmuch as they are known from pelagic sediments, but they are more typical of shallow water. Glauconite usually occurs at shallow to moderate depths where conditions are mildly oxidizing and accumulation rates are slow.

The limestones were probably exposed to fresh-water circulation to form the extensive leached porosity. Since pelagic sediments immediately overlie unit 8 with no apparent hiatus, the leaching probably occurred very soon after deposition while the sediments were still near sea level.

In the limestone at the upper contact of unit 8 , ferruginous red clay fills some pores and manganese oxide "dendrites" line some cracks. These may reflect subaerial exposure, but they might also have formed on a deeply submerged sea floor prior to deposition of the overlying red marly ooze of unit 7 .

Neomorphism (inversion and/or recrystallization) is evident in several samples. It may have occurred during mineralogic stabilization (inversion) of biogenic aragonite to diagenetic calcite, and may record exposure to fresh water, although this is by no means the only possible explanation.

We cannot determine the exact time of cementation. Some cementation obviously preceded leaching as evidenced by cement crystals nucleated on fossils that were subsequently leached to form molds and cement that has been truncated by vugs. But we cannot be certain that all the cement preceded leaching. Lack of compaction, a frequently cited criterion for early cementation in limestones, provides no real clues in this case. Although the limestones of unit 8 have not been compacted, they may never have been covered by more than 160 meters of unlithified sediment. Moreover, the overlying unlithified oozes have not been compacted in as much as 105 m.y.

\section{Nannofossil Oozes}

The onset of deposition of nannofossil ooze in Barremian or Aptian time abruptly followed the cessation of deposition and diagenesis of shallow-water limestones. Although 


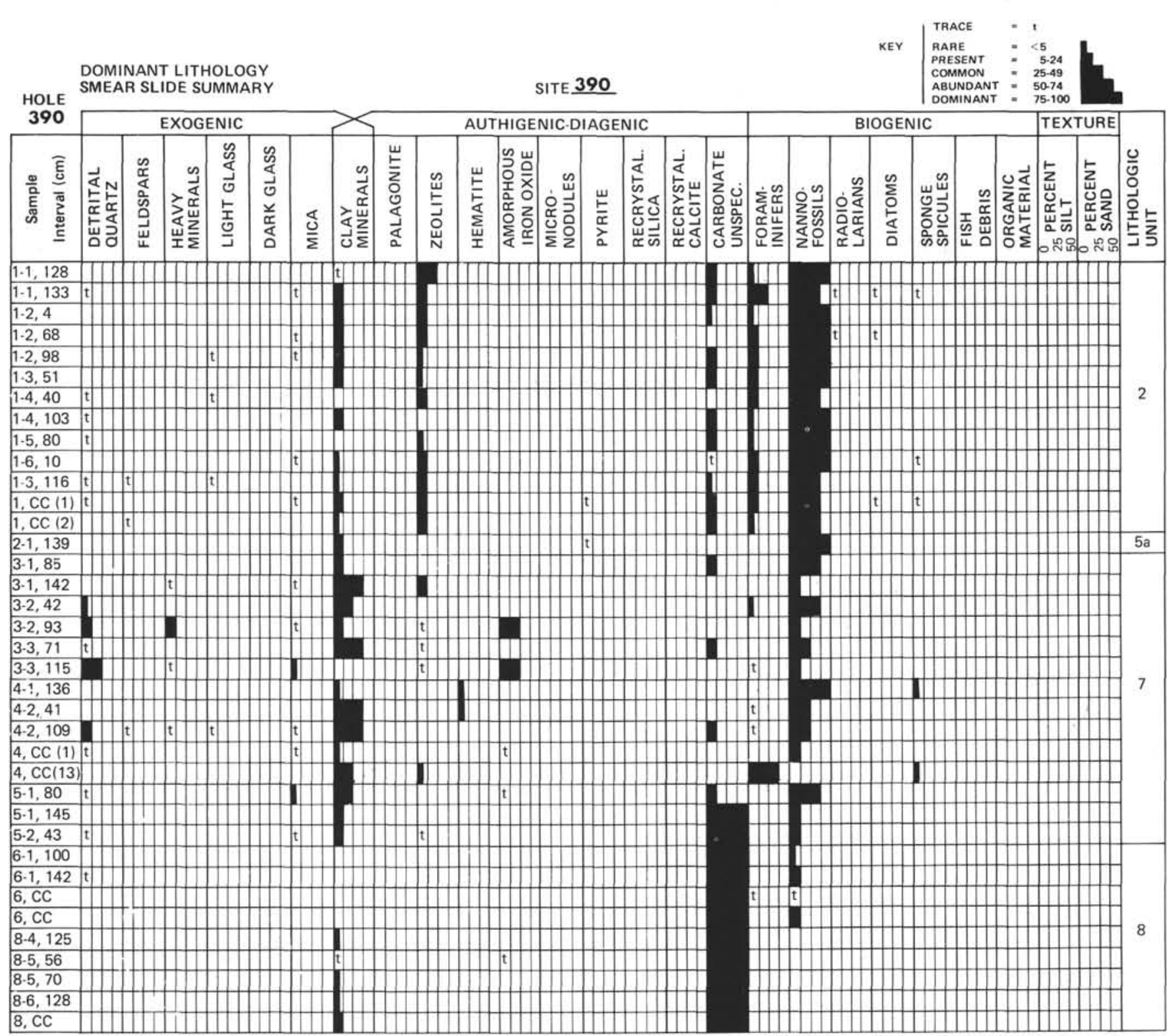

Figure 11. Estimate of major components in dominant lithologies from smear slides, Hole 390.

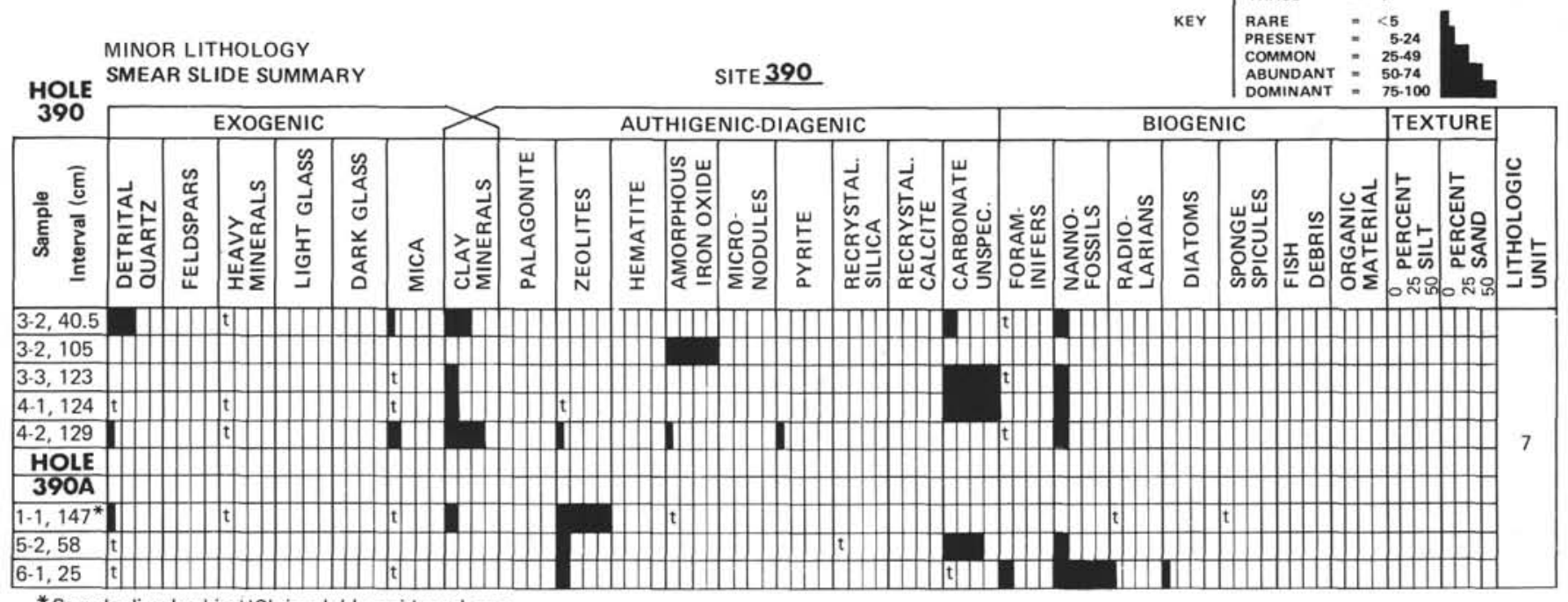

* Sample dissolved in $\mathrm{HCl}$, insoluble residues shown

Figure 12. Estimate of major components in minor lithologies from smear slides, Hole 390 and $390 \mathrm{~A}$. 


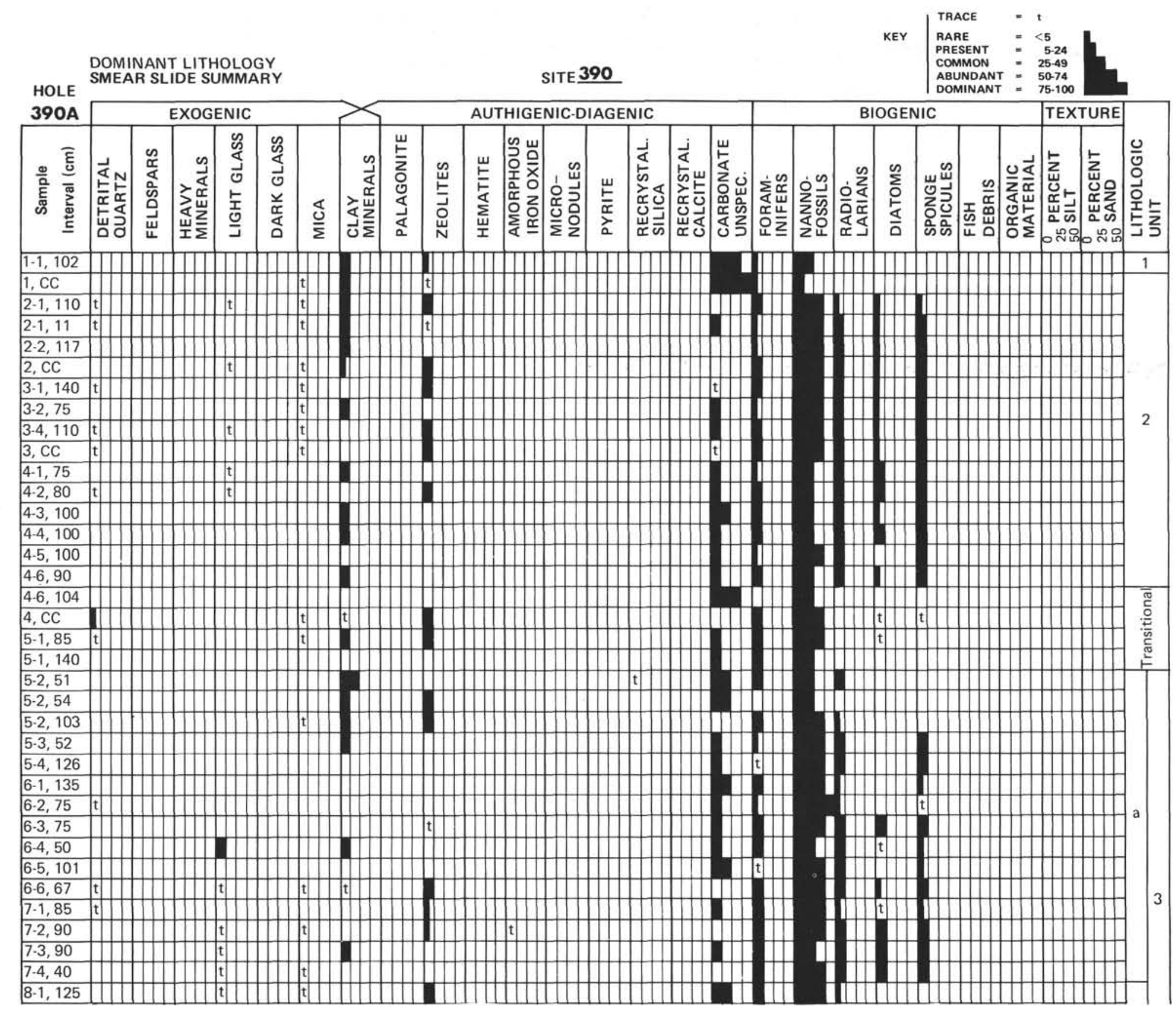

Figure 13. Estimate of major components in dominant lithologies from smear slides, Hole $390 \mathrm{~A}$. 


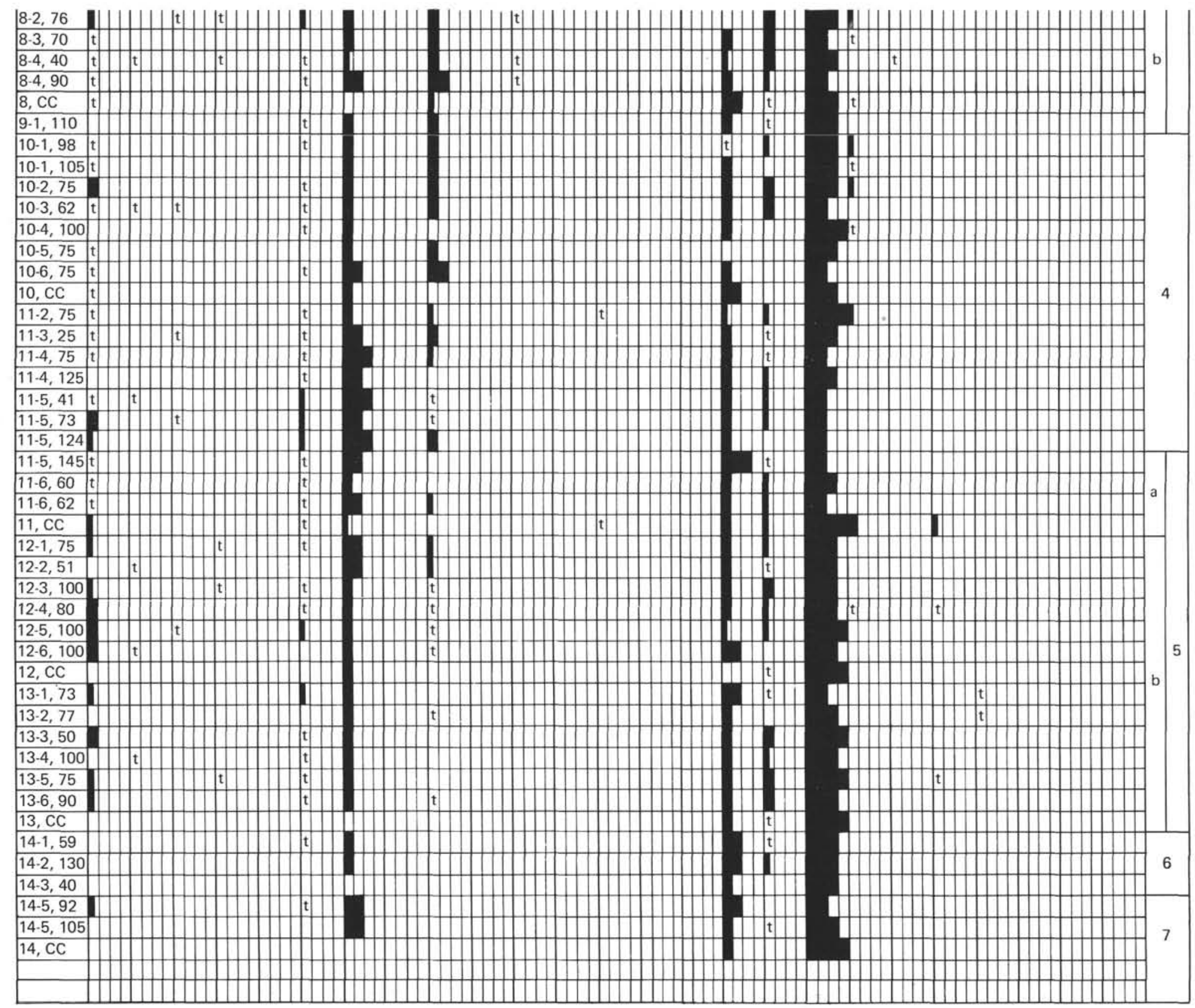




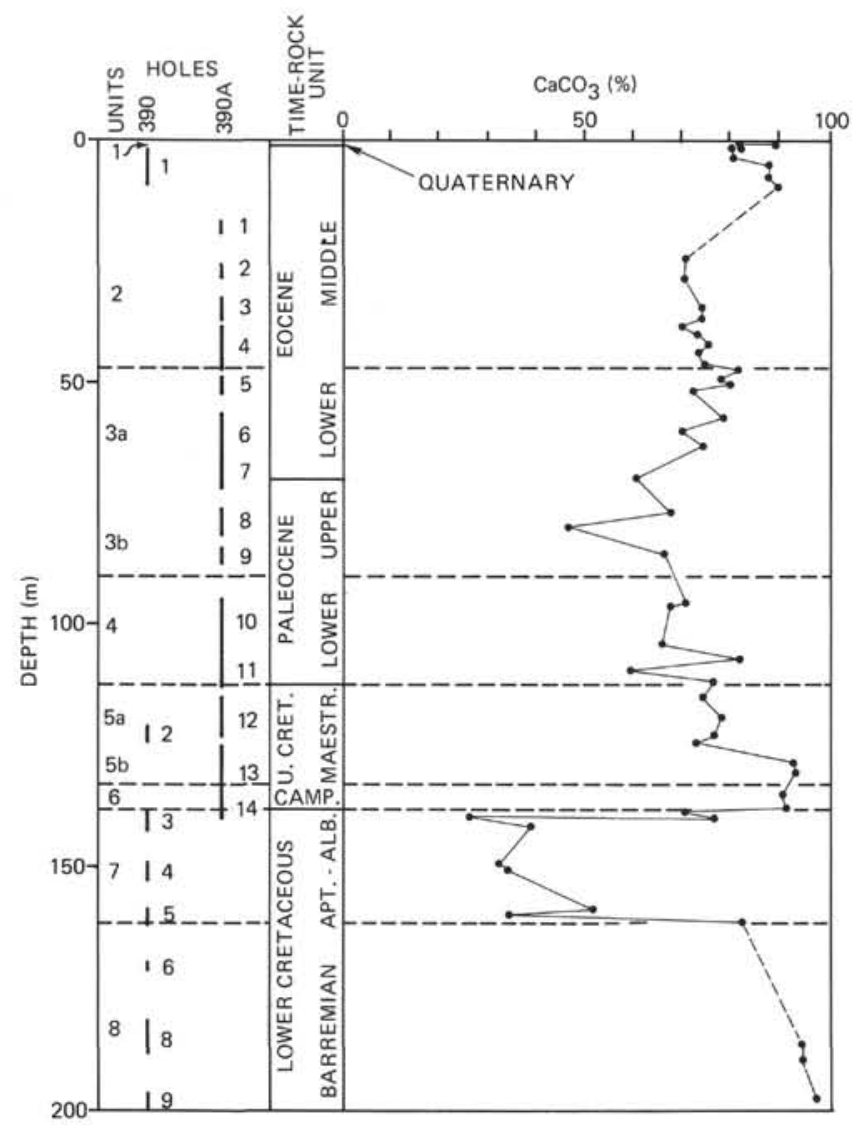

Figure 14. Carbonate contents in sediments from Holes 390 and 390A. (Percentages determined from on board "bomb" procedure.)

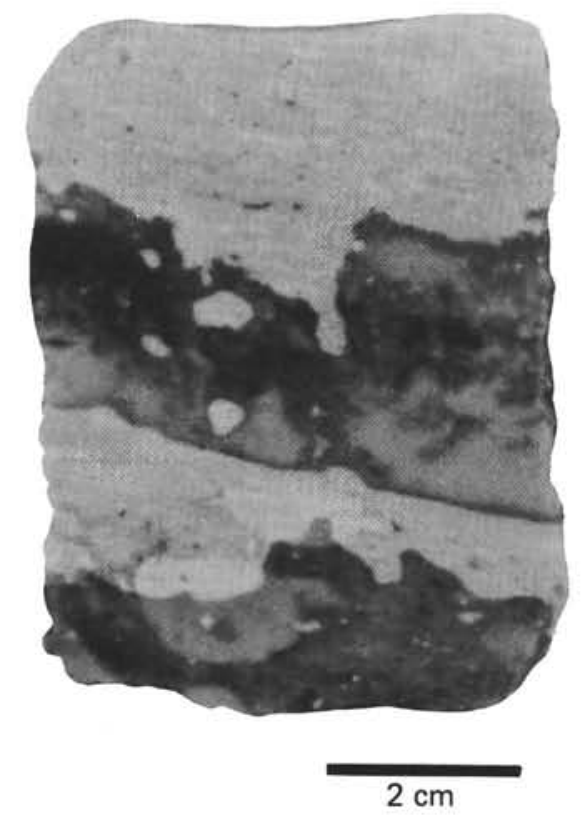

Figure 15. Chert in limestone of llthologic unit 3, Sample $390 A-6, C C$. Note very irregular contacts which suggest chert replaced carbonate.
TABLE 5

Clay and Carbonate Contents (\%) of Variegated Sediments, Unit 7. Estimates are From Smear Slides, Adjusted by Carbonate Bomb Data Where Available.

\begin{tabular}{cccc}
\hline & \multicolumn{3}{c}{ Color (No. Analyses) } \\
& Red (4) & Light brown (3) & $\begin{array}{c}\text { Light gray } \\
\text { or white (7) }\end{array}$ \\
\hline $\begin{array}{c}\text { Clay } \\
\text { (range) }\end{array}$ & 60 & 35 & 14 \\
$\begin{array}{c}\text { Carbonate } \\
\text { (range) }\end{array}$ & $39-70)$ & $(15-65)$ & $(4-30)$ \\
\hline
\end{tabular}

pelagic ooze may be deposited at various depths, it usually represents deposition at a minimum depth of 500 meters. This implies that the area subsided very rapidly during a time interval not greater than a few million years.

\section{Origin of Variegated Ooze}

The marly nannofossil ooze of unit 7 is variegated, red, brown, and white - unusual colors for carbonate-rich pelagic sediments. The red color presumably derives from the clay fraction, as indicated by the positive correlation between redness and clay content (Table 4). The pigment was probably supplied as fine-grained ferric oxides transported along with clay minerals eroded from terrestrial sources such as pre-Tertiary red soils of the Appalachian piedmont (Juergen Reinhardt, personal communication), red sediments in the coastal plain, or erosion of Triassic red beds. In situ oxidation of the iron, for example by subaerial exposure, probably did not occur in view of the nearly continuous history of pelagic deposition during post-Barremian Cretaceous and early Tertiary time. We detected no evidence of subaerial exposure surfaces or submarine hardgrounds. On the contrary, red coloration appears to be pervasive within distinct sedimentation units, except for burrow mottles. No streaking of underlying units or abrupt truncations at the top of red units is evident.

If the iron was supplied as finely dispersed, detrital ferric oxides, how are the interlayered white, light gray, and a few greenish gray sediments to be explained? The simplest answer is variations in the balance between detrital influx and pelagic carbonate sedimentation owing to differences of sediment transport on and from the continent and of skeletal carbonate production. In situ reduction of detrital iron could have taken place, especially in the case of greenish gray laminae. The greatly reduced incidence of burrows in the lighter layers might indicate stagnant conditions inimical to bottom life, but could also be caused by more rapid sedimentation rates. Extreme reducing conditions, which appear necessary to account for the extensive deposition of black, organic carbon-rich clay in the western North Atlantic basin at least as early as Albian time (DSDP Leg 11, Site $105)$, must not have been prevalent on the Blake Nose where Albian red sediment was being deposited.

\section{Lithification of Calcareous Oozes}

Calcareous nannofossil oozes of units 4 through 7 are unlithified despite ages ranging from 60 to $100 \mathrm{~m} . \mathrm{y}$. Certainly cementation on the sea floor prior to burial was not very active. 
TABLE 6

Limestone Fragments Recovered From Unit 8

\begin{tabular}{|c|c|c|c|c|}
\hline Core/Sect. & Lithology & Particles & Porosity & Remarks \\
\hline $5, \mathrm{CC}$ & Wackestone & $\begin{array}{l}\text { Skeletal fragments, } \\
\text { pelecypods }\end{array}$ & $5 \%-10 \%$, skeletal molds & $\begin{array}{l}\text { At contact with unit } 7 \text {. Red clay fills some } \\
\text { molds. Manganese dendrites. }\end{array}$ \\
\hline $6-1$ & Wackestone & $\begin{array}{l}\text { Skeletal fragments, } \\
\text { incl. pelecypods, } \\
\text { ammonite }\end{array}$ & $5 \%$ & \\
\hline $6, \mathrm{CC}$ & Grainstone & $\begin{array}{l}\text { Ooids, grapestone, } \\
\text { pelecypods, spirorbid } \\
\text { worms }\end{array}$ & $\begin{array}{l}<5 \% \text {, intergranular, } \\
\text { moldic }\end{array}$ & $\begin{array}{l}\text { Thin section. Two generations of calcite cemen } \\
\text { cement, limonite staining. Ooid nucleii are } \\
\text { miliolids and other benthic foraminifers (inc. } \\
\text { Trocholina sp.), mollusk fragments, pelletoids. } \\
\text { White. }\end{array}$ \\
\hline $6, \mathrm{CC}$ & Packstone & $\begin{array}{l}\text { Glauconite pelletoids, } \\
\text { gastropods, pelecypod } \\
\text { fragments }\end{array}$ & Nil & \\
\hline $6, \mathrm{CC}$ & Packstone & $\begin{array}{l}\text { Brachiopods?, skeletal } \\
\text { fragments, glauconite } \\
\text { pelletoids }\end{array}$ & Nil & Light brown \\
\hline $8-5$ & Wackestone & $\begin{array}{l}\text { Microfossils or skeletal } \\
\text { fragments }\end{array}$ & $\begin{array}{l}<2 \% \text {, fractures } \\
\text { (desiccation?) }\end{array}$ & $\begin{array}{l}\text { Laminated; yellow }(10 \text { YR } 8 / 6) \text { and white } \\
(10 \text { YR } 8 / 2) \text {. }\end{array}$ \\
\hline $9-1$ & Mudstone? & $\begin{array}{l}\text { Microcrystalline } \\
\text { calcite }\end{array}$ & $20 \%$, moldic or vuggy & Extension neomorphism (recrystallization). \\
\hline 9, CC & Wackestone & Pelletoids, microfossils & $\begin{array}{l}40 \% \text {, vuggy, inter- } \\
\text { granular? }\end{array}$ & Micrite; sparry cement. \\
\hline $10, \mathrm{CC}$ & Wackestone & $\begin{array}{l}\text { Gastropods, green } \\
\text { algae?, foraminifers?, } \\
\text { pelecypods }\end{array}$ & $10 \%$, skeletal molds & $\begin{array}{l}\text { Thin section. Black, opaque stain, probably } \\
\text { manganese, in molds, locally permeates matrix. } \\
\text { Small lines borings (worms?) in periphery of } \\
\text { clasts. }\end{array}$ \\
\hline
\end{tabular}

Unit 3, however, is significantly lithified. As exposure to any water other than seawater and marine pore water is improbable, cementation presumably occurred either on the sea floor or within the sediment column. The usual criteria for "'hardgrounds," such as borings, encrustations, truncation surfaces, reworked pebbles, and staining by manganese or iron oxides, are absent, and the close association of limestone with chert (Figure 15) suggests lithification below the sediment surface. Seawater is generally undersaturated with respect to amorphous silica and is supersaturated with respect to calcite at depths less than 4000 meters in the Atlantic Ocean at present. Thus, replacement chert of the type encountered in unit $3 \mathrm{~b}$ (see above) is not usual near the sediment surface. Stratigraphic evidence from the Deep Sea Drilling Project also suggests that chert forms well down within the sediment (Calvert, 1974). The association of limestone with chert suggests that the calcium carbonate, dissolved to make room for silica, may be redeposited as cement in the immediate vicinity. Association in space, however, does not prove association in time. The sources of silica in unit $3 \mathrm{~b}$ are limited; siliceous organisms are virtually lacking (Figure 13), although they are abundant in the overlying units $3 \mathrm{a}$ and 2 . No volcanic sediments or particles were encountered anywhere in Holes 390 or 390 A.

\section{Summary and Discussion}

Although the Blake Nose is part of the continental margin, its sedimentary history since Early Cretaceous time reflects oceanic influences much more strongly than continental influences. This applies to accumulation rates, types of sediment, and probably to hiatuses in the record.

The oldest sediment cored is a Barremian or older shallow-water limestone, which may have been exposed early in its history. The overlying six units are nannofossil oozes representing a fairly complete Aptian through middle Eocene section condensed into only 160 meters. A major hiatus exists between middle Eocene and Quaternary.

Workers have long recognized that at least some parts of the Blake Plateau are currently subject to bypassing or perhaps to actively eroding bottom currents, including the Gulf Stream (Milliman et al., 1972). Sediment transport across areas of non-deposition may have occurred

TABLE 7

Correlation of Lithologic Boundaries With Biostratigraphic Boundaries

\begin{tabular}{|c|c|c|c|}
\hline $\begin{array}{l}\text { Lithologic } \\
\text { Boundaries }\end{array}$ & Recovered & $\begin{array}{c}\text { Location } \\
\text { Hole } / \text { Core } / \text { Sect. } / \mathrm{cm}\end{array}$ & $\begin{array}{l}\text { Biostratigraphic } \\
\text { Boundaries }\end{array}$ \\
\hline Units $1 / 2$ & Yes & $390-1-1,113$ & Quaternary/Eocene \\
\hline Units $2 / 3$ & Yes & $\begin{array}{c}390 \mathrm{~A}-4-6,97 \\
\text { to } \\
390 \mathrm{~A}-5-2,51\end{array}$ & $\begin{array}{l}\text { Middle/lower Eocene } \\
\text { (at top of transition) }\end{array}$ \\
\hline Sub-units $3 a / 3 b$ & Yes & $390 \mathrm{~A} \cdot 7-4,140$ & Eocene/Paleocene \\
\hline Units $3 / 4$ & No & $\begin{array}{l}\text { Between } \\
390 \mathrm{~A}-9 \text { and } 390 \mathrm{~A}-10\end{array}$ & \\
\hline Units $4 / 5$ & Yes & $390 \mathrm{~A}-11-5,140$ & $\begin{array}{l}\text { Paleocene/Maestrichtian } \\
\text { (Tertiary/Cretaceous) }\end{array}$ \\
\hline Sub-units $5 \mathrm{a} / 5 \mathrm{~b}$ & Yes & $390 A-13-2,50$ & Upper/lower Maestrich tian \\
\hline Units $5 / 6$ & No & $\begin{array}{l}\text { Between } \\
390 \mathrm{~A}-13 \text { and } 390 \mathrm{~A}-14 \\
(390-2 \text { and } 390-3)\end{array}$ & \\
\hline Within Unit 6 & Yes & $390 \mathrm{~A}-14-5,50$ & Maestrichtian/Campanian \\
\hline Units $6 / 7$ & Yes & $390 \mathrm{~A}-14-5,80$ & Campanian/Albian \\
\hline Unit 7 & No & Between 3904 and 5 & Albian/Aptian \\
\hline Units $7 / 8$ & Yes & $390-5$, CC 10 & Aptian/Barremian-lower Albian \\
\hline
\end{tabular}


continuously or active erosion may have occurred intermittently on the Blake Nose since the Eocene, thus leaving the Eocene exposed.

Intermittent bypassing or erosion could also have caused the other hiatuses, but we would view this with caution as other hiatuses are marked only by slight nuances in sedimentation. Except for the present veneer, evidence of bypassing such as lag deposits or chemical sedimentation of manganese, iron, or even calcium carbonate (hardgrounds; criteria mentioned above) are lacking. Bypassing, although a tempting explanation for the relatively condensed sequence, does not seem adequate. Certainly an unusual filter would be required to allow deposition of nearly pure nannofossil ooze while permitting coarser components to pass. Variations in abundance of very slowly soluble and relatively large biogenic components, such as radiolarians and sponge spicules, are commonly explained by variations in productivity of the water mass. This explanation may more reasonably account for variations in biogenic carbonate accumulation rates at Site 390 than does partial bypassing.

A further argument for the role of productivity in carbonate accumulation is the roughly inverse relationship between accumulation rate and terrigenous detrital content (Figure 16). If high accumulation rates were the result of increased detrital influx, they should correspond to the more clay-rich units; this is normally the case for intracratonic basins. The inverse relationship suggests that high sedimentation rates result from high skeletal productivity which dilutes the terrigenous detrital contribution. This is the usual pattern in deep-sea sediments and the Blake Nose shows this pattern at the continental margin.

\section{GEOCHEMISTRY}

We did not make geochemical determinations on samples from the single core collected at Site 389 . The geochemistry program at Site 390 was: (1) to collect samples for general geochemistry study; (2) to analyze interstitial water from squeezed sediment samples at approximately 50-meter

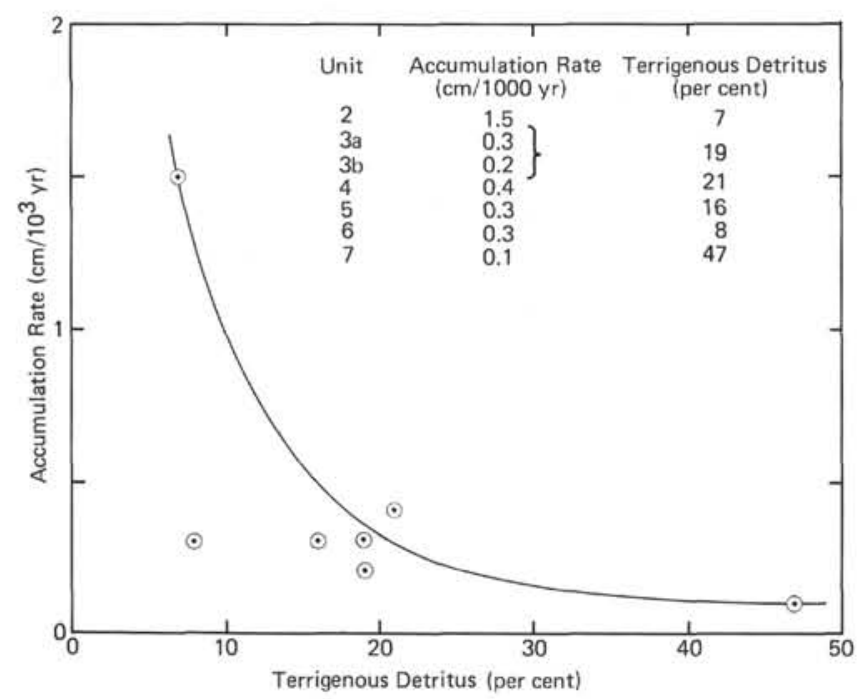

Figure 16. Sediment accumulation rates compared to content of terrigenous detritus (clay plus quartz), on basis of smear slide analyses adjusted to carbonate content (bomb). intervals; and (3) to determine the methane and ethane content of any gas detected in the cores. (We did not detect gas in any cores from this site.)

The results of the general geochemistry studies are reported in the Geochemistry section of this volume.

We analyzed five interstitial water samples following the procedure, with minor modification, of Gieskes (1974), and Gieskes and Lawrence (1976). Results of the $p \mathrm{H}$, alkalinity, chlorinity, salinity, and calcium and magnesium determinations are given on Table 8 and Figure 17. As samples from 140 meters were analyzed from both Hole 390 and Hole $390 \mathrm{~A}$, the data should be comparable, provided there are no significant horizontal variations in the beds themselves. Data for $\mathrm{Ca}, \mathrm{Mg}$, chlorinity, and $\mathrm{pH}$ for the two holes are well within the limits of experimental error. Alkalinity, however, differs by $0.12 \mathrm{meq} / \mathrm{kg}$ and salinity differs by $1.0 \%$. Since the squeezed water samples from Hole $390 \mathrm{~A}$ were stored for approximately nine hours before the alkalinity analysis and those from Hole 390 were analyzed immediately, the difference in alkalinity may be a result of air oxidation or gas exchange during sample storage. Salinity was determined with a hand-held refractometer by which density is measured and salinity can be calculated. The measurement is crude and, although careful reading under ideal conditions can yield salinity to $\pm 0.4 \%$, variations of $\pm 1.0 \%$ are not unreasonable.

Calcium and magnesium gradients, though small, are real and changes are linearly correlated with $\Delta \mathrm{Ca}^{++} / \Delta \mathrm{Mg}$ $=-0.8$.

\section{PHYSICAL PROPERTIES}

Measurements of sonic velocity, wet bulk density, water content and shear strength were taken on cores from Holes 390 and 390A. (The single core recovered from Hole 389 consisted of an artificially graded sequence of Mn-foraminifer sand and manganese nodules on which no physical measurements were made.)

We took a mudline core in Hole 390 and the remaining eight cores of that hole from between 123-206 meters sub-bottom. The intervening 123 meters were cored in Hole $390 \mathrm{~A}$, thus completing the section. The physical properties data are given in Tables 9 and 10 and average values for each of the eight lithologic units are summarized in Tables 11, 12, 13 and 14.

\section{Sonic Velocity and Impedance}

Sonic velocities were determined using the Hamilton Frame velocimeter; the procedure is described by Boyce, 1973. Accuracy of the technique is $\pm 2 \%$ and precision of the velocimeter was verified with 10 repeated measurements each of lucite and brass standards. All cores were allowed to equilibrate with laboratory temperatures $\left(25^{\circ} \mathrm{C}\right)$ and measurements were made at $5.0 \mathrm{microsec} / \mathrm{cm}$ on split sediment sections (perpendicular to the core barrel and approximately parallel to bedding). We measured velocities at 15 places in cores from Hole 390 and at 81 places in cores from Hole 390A (Table 9). Average velocities of each lithologic unit are given on Table 11.

Velocities increase downhole and the greatest rates of increase occur: (1) between units $3 \mathrm{~b}$ (nannofossil ooze with chert and limestone) and 4 (zeolitic nannofossil ooze) no 
TABLE 8

Summary of Interstitial Water Data, Site 390

\begin{tabular}{lccccccc}
\hline \multicolumn{1}{c}{ Sample } & $\begin{array}{c}\text { Sub-Bottom } \\
\text { Depth top (m) }\end{array}$ & $\mathrm{pH}$ & $\begin{array}{c}\text { Alkalinity } \\
\mathrm{meg} / \mathrm{kg}\end{array}$ & $\begin{array}{c}\text { Salinity } \\
0 / 00\end{array}$ & $\begin{array}{c}\mathrm{Ca}^{++} \\
\mathrm{mmoles} / \mathrm{l}\end{array}$ & $\begin{array}{c}\mathrm{mg}^{++} \\
\mathrm{mmoles} / \mathrm{l}\end{array}$ & $\begin{array}{c}\mathrm{Cl}^{-} \\
0 / 00\end{array}$ \\
\hline $\begin{array}{l}\text { IAPSO } \\
\text { STD Sea Water }\end{array}$ & - & 7.90 & 2.42 & 35.2 & - & - & - \\
Surface Sea Water & - & 8.30 & 2.43 & 36.3 & 10.63 & 55.17 & 20.10 \\
& & & & & & & \\
Hole 390 & 3.2 & 7.5 & 2.20 & 35.2 & 10.35 & 52.48 & 19.64 \\
1-2, 140-150 & 136.2 & 7.5 & 2.43 & 36.3 & 16.38 & 44.50 & 19.51 \\
3-2, 140-150 & & & & & & & \\
Hole 390A & 33.2 & 7.6 & 2.39 & 35.8 & 11.24 & 51.13 & 19.51 \\
3-3, 140-150 & 80.7 & 7.5 & 2.50 & 35.8 & 14.00 & 48.37 & 19.31 \\
8-3, 140-150 & 139.2 & 7.4 & 2.55 & 35.2 & 14.95 & 45.17 & 19.57 \\
$14-4,140-150$ & & & & & & &
\end{tabular}

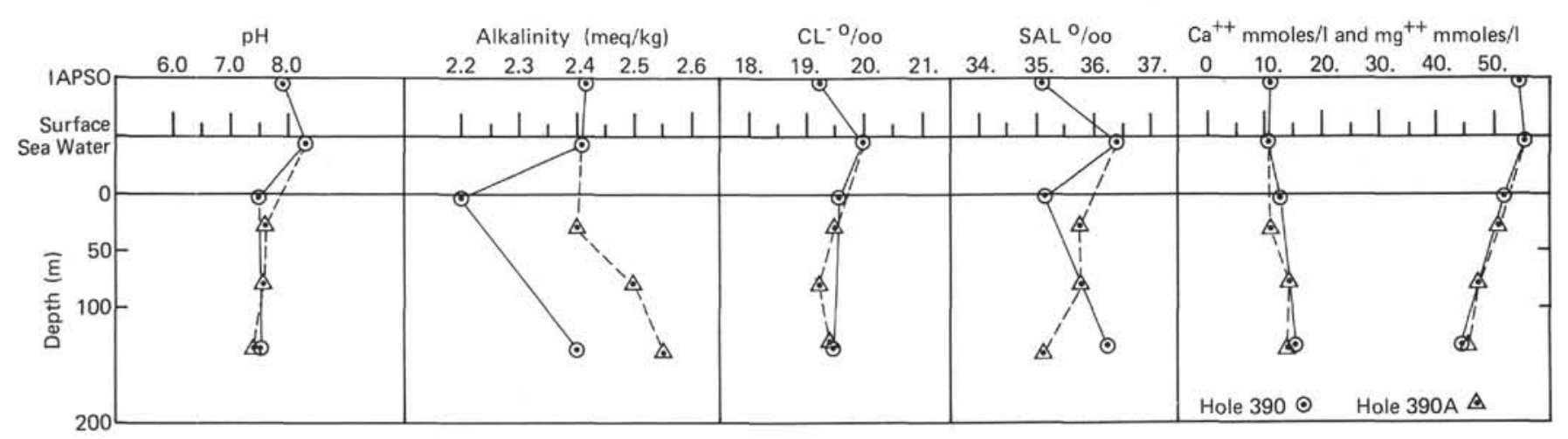

Figure 17. Interstitial water data, Holes 390 and 390A.

velocities, however, were measured on the lithified parts of unit $3 \mathrm{~b}$, so the average velocity of unit $3 \mathrm{~b}$ is probably higher than shown, (2) across the Maestrichtian-Danian boundary, and (3) between units 6 and 7 which straddle an Albian/Campanian unconformity. The velocities of unit $5 b$ are markedly lower than the overlying unit 5a.

Impedance is defined as sonic velocity times density and is recorded for intervals where velocity and density data were taken from the same sample. Densities were determined by the "syringe", technique on board ship (see below). Impedance values are plotted on Figure 18.

Values for Core 1, Hole 390, are scattered between 2.25 and $2.80 \times 10^{5} \mathrm{~g} / \mathrm{cm}^{2} \mathrm{sec}$. Impedance "jumps" in Core 3 (unit 7) to $2.67-3.61 \times 10^{5} \mathrm{gm} / \mathrm{cm}^{2} \mathrm{sec}$ and continues to increase downhole. The overlying 123 meters were not cored at Hole 390, however, in Hole 390A a similar "jump", occurs between units 6 and 7, across an Albian/Campanian unconformity (Campanian).

\section{Water Content, Porosity, and Wet Bulk Density}

Water content is expressed as per cent weight of the evaporated water relative to the weight of the wet sample.

$$
\% \text { water content }=\frac{\text { wt. evaporated water } \times 100}{\text { wt. wet sediment }}
$$

Water contents (\%) were determined on 14 samples from Hole 390 and 41 samples from Hole 390A. The data are given on Table 10 and averages for each lithologic unit are given on Table 12.

The water content in the sediments decreases downhole. The sharpest breaks occur between lithologic units $3 \mathrm{a}$ and $3 \mathrm{~b}$, 4 and 5 , and between units 6 and 7 .

Porosity (\%) was determined by measuring weight of evaporated water and volume of the wet sediment. Volume is measured directly from the ml-syringe sampler ("syringe", method). This assumes that pore space was filled with water.

$$
\% \text { porosity }=\frac{\text { wt. evaporated water } \times 100}{\text { volume wet sediment }}
$$

We determined porosities for 14 samples from Hole 390 and 41 samples from Hole $390 \mathrm{~A}$. They ranged between 39.4 and 72.7 per cent and averages for each lithologic unit are given in Table 13.

Porosity decreased downhole and significant changes in porosity occur between units $3 \mathrm{~b}$ and 4 , and units 6 and 7 .

We routinely measured wet bulk density by continuous scan of the Gamma Ray Attenuation Porosity Evaluator (GRAPE) and by direct measurement.

$$
\text { Wet bulk density }=\frac{\text { volume wet sediment }}{\text { wt. wet sediment }}
$$

Volume is measured directly from the ml-syringe sampler ("syringe", method). 
TABLE 9

Sonic Velocity Measurements, Holes 390 and 390A

\begin{tabular}{|c|c|c|c|c|c|}
\hline $\begin{array}{c}\text { Sample } \\
\text { (Interval in } \mathrm{cm} \text { ) }\end{array}$ & $\begin{array}{l}\text { Depth in } \\
\text { Hole }(\mathrm{m})\end{array}$ & $\begin{array}{l}\text { Velocitya } \\
(\mathrm{km} / \mathrm{sec})\end{array}$ & $\begin{array}{c}\text { Impedance } \\
\left(\mathrm{g} / \mathrm{cm}^{2} \sec \times 10^{5}\right)\end{array}$ & $\begin{array}{l}\text { Lithologic } \\
\text { Unit }\end{array}$ & Lithology \\
\hline \multicolumn{6}{|l|}{ Hole 390} \\
\hline $1-3,37$ & 3.37 & 1.54 & 2.46 & 2 & Nannofossil ooze \\
\hline $1-3,128$ & 4.28 & 1.43 & & 2 & Nannofossil ooze \\
\hline $1-4,46$ & 4.96 & 1.44 & 2.30 & 2 & Nannofossil ooze \\
\hline $1-4,99$ & 5.49 & 1.53 & & 2 & Nannofossil ooze \\
\hline $1-5,40$ & 6.40 & 1.66 & 2.81 & 2 & Nannofossil ooze \\
\hline $1-5,105$ & 7.05 & 1.52 & & 2 & Nannofossil ooze \\
\hline $1-6,55$ & 8.05 & 1.48 & 2.26 & 2 & Nannofossil ooze \\
\hline $1-6,103$ & 8.53 & 1.52 & & 2 & Nannofossil ooze \\
\hline $3-2,30$ & 134.80 & 1.59 & & 7 & Clay and nannofossil ooze \\
\hline $3-2,73$ & 135.23 & 1.57 & & 7 & Clay and nannofossil ooze \\
\hline $3-3,39$ & 136.39 & 1.64 & & 7 & Nannofossil clay \\
\hline $3-3,72$ & 136.72 & 1.62 & & 7 & Nannofossil clay \\
\hline $4-2,52$ & 144.52 & 1.59 & 2.83 & 7 & Marly nannofossil ooze \\
\hline $4-2,95$ & 144.95 & 1.58 & & 7 & Marly nannofossil ooze \\
\hline $5-2,44$ & 153.94 & 1.72 & & 7 & Nannofossil chalk \\
\hline $5-2,105$ & 154.55 & 1.68 & 3.61 & 7 & Nannofossil chalk \\
\hline \multicolumn{6}{|l|}{ Hole 390A } \\
\hline $2-2,22$ & 20.72 & 1.50 & & 2 & Siliceous nannofossil ooze \\
\hline $2-2,60$ & 21.10 & 1.49 & 2.31 & 2 & Siliceous nannofossil ooze \\
\hline $2-2,102$ & 21.52 & 1.49 & & 2 & Siliceous nannofossil ooze \\
\hline $2-3,34$ & 30.34 & 1.51 & & 2 & Siliceous nannofossil ooze \\
\hline $3-2,87$ & 30.87 & 1.50 & 2.28 & 2 & Siliceous nannofossil ooze \\
\hline $3-3,31$ & 31.81 & 1.52 & 2.31 & 2 & Siliceous nannofossil ooze \\
\hline $3-3,70$ & 32.20 & 1.53 & & 2 & Siliceous nannofossil ooze \\
\hline $4-2,45$ & 40.35 & 1.53 & 2.34 & 2 & Siliceous nannofossil ooze \\
\hline $4-2,86$ & 40.76 & 1.53 & & 2 & Siliceous nannofossil ooze \\
\hline $4-3,31$ & 41.71 & 1.52 & & 2 & Siliceous nannofossil ooze \\
\hline $4-3,105$ & 42.45 & 1.49 & & 2 & Siliceous nannofossil ooze \\
\hline $4-4,24$ & 43.14 & 1.53 & & 2 & Siliceous nannofossil ooze \\
\hline $4-4,89$ & 43.79 & 1.52 & 2.27 & 2 & Siliceous nannofossil ooze \\
\hline $4-5,47$ & 44.87 & 1.50 & 2.25 & 2 & Siliceous nannofossil ooze \\
\hline $4-5,131$ & 45.71 & 1.52 & & 2 & Siliceous nannofossil ooze \\
\hline $4-6,35$ & 46.25 & 1.59 & & 2 & Siliceous nannofossil ooze \\
\hline $4-6,88$ & 46.78 & 1.58 & 2.51 & 2 & Siliceous nannofossil ooze \\
\hline $5-2,108$ & 50.08 & 1.53 & & $3 \mathrm{a}$ & Nannofossil chalk \\
\hline $5-3,34$ & 50.84 & 1.53 & 2.20 & $3 \mathrm{a}$ & Siliceous nannofossil ooze \\
\hline $5-3,100$ & 51.50 & 1.52 & & $3 \mathrm{a}$ & Siliceous nannofossil ooze \\
\hline $6-2,12$ & 59.02 & 1.54 & & $3 a$ & Nannofossil ooze \\
\hline $6-2,91$ & 59.81 & 1.54 & 2.23 & 3a & Nannofossil ooze \\
\hline $6-3,29$ & 60.69 & 1.51 & & $3 \mathrm{a}$ & Siliceous nannofossil ooze \\
\hline $6-3,116$ & 61.56 & 1.53 & 2.31 & 3a & Siliceous nannofossil ooze \\
\hline $6-4,30$ & 62.20 & 1.51 & 2.61 & $3 \mathrm{a}$ & Siliceous nannofossil ooze \\
\hline $6-4,107$ & 62.97 & 1.53 & & $3 a$ & Siliceous nannofossil ooze \\
\hline $6-5,35$ & 63.75 & 1.55 & & $3 a$ & Siliceous nannof ossil ooze \\
\hline $6-5,102$ & 64.42 & 1.52 & 2.28 & $3 \mathrm{a}$ & Siliceous nannofossil ooze \\
\hline $6-6,113$ & 66.03 & 1.55 & 2.68 & $3 \mathrm{a}$ & Siliceous nannofossil ooze \\
\hline $7-4,13$ & 71.13 & 1.54 & & $3 \mathrm{a}$ & Siliceous nannofossil ooze \\
\hline $7-4,55$ & 71.55 & 1.53 & 2.16 & $3 a$ & Siliceous nannofossil ooze \\
\hline $8-2,92$ & 78.42 & 1.52 & & $3 \mathrm{~b}$ & Nannofossil ooze \\
\hline $8-3,30$ & 79.30 & 1.57 & & $3 \mathrm{~b}$ & Nannofossil ooze \\
\hline $8-3,69$ & 79.69 & 1.58 & & $3 b$ & Nannofossil ooze \\
\hline $8-4,25$ & 80.75 & 1.57 & & $3 \mathrm{~b}$ & Nannofossil ooze \\
\hline $9-1,108$ & 86.58 & 1.61 & & 4 & Zeolitic nannofossil ooze \\
\hline $10-1,19$ & 95.59 & 1.61 & & 4 & Zeolitic marly nannofossil ooze \\
\hline $10-1,63$ & 96.03 & 1.64 & & 4 & Zeolitic marly nannofossil ooze \\
\hline $10-1,115$ & 96.55 & 1.66 & & 4 & Zeolitic marly nannofossil ooze \\
\hline $20-2,80$ & 97.70 & 1.65 & & 4 & Zeolitic marly nannofossil ooze \\
\hline $10-3,40$ & 98.80 & 1.66 & 2.95 & 4 & Zeolitic marly nannofossil ooze \\
\hline $10-3,112$ & 99.52 & 1.64 & & 4 & Zeolitic marly nannofossil ooze \\
\hline $10-4,74$ & 100.64 & 1.64 & & 4 & Zeolitic marly nannofossil ooze \\
\hline $10-5,25$ & 101.65 & 1.64 & & 4 & Zeolitic marly nannofossil ooze \\
\hline $10-5,104$ & 102.44 & 1.65 & 3.00 & 4 & Zeolitic marly nannofossil ooze \\
\hline $10-6,50$ & 103.40 & 1.67 & & 4 & Zeolitic marly nannofossil ooze \\
\hline $11-2,70$ & 106.70 & 1.58 & 2.84 & 4 & Nannofossil ooze \\
\hline $11-2,122$ & 107.22 & 1.63 & & 4 & Nannofossil ooze \\
\hline
\end{tabular}


TABLE 9 - Continued

\begin{tabular}{|c|c|c|c|c|c|}
\hline $\begin{array}{c}\text { Sample } \\
\text { (Interval in } \mathrm{cm} \text { ) }\end{array}$ & $\begin{array}{l}\text { Depth in } \\
\text { Hole (m) }\end{array}$ & $\begin{array}{l}\text { Velocity }{ }^{\mathrm{a}} \\
(\mathrm{km} / \mathrm{sec})\end{array}$ & $\begin{array}{c}\text { Impedance } \\
\left(\mathrm{g} / \mathrm{cm}^{2} \sec \times 10^{5}\right)\end{array}$ & $\begin{array}{l}\text { Lithologic } \\
\text { Unit }\end{array}$ & Lithology \\
\hline $11-3,37$ & 107.87 & 1.63 & & 4 & Marly nannofossil ooze \\
\hline $11-3,106$ & 108.56 & 1.61 & & 4 & Marly nannofossil ooze \\
\hline $11-4,39$ & 109.39 & 1.59 & 2.91 & 4 & Marly nannofossil ooze \\
\hline $11-4,117$ & 110.17 & 1.65 & & 4 & Marly nannofossil ooze \\
\hline $11-5,39$ & 110.89 & 1.62 & & 4 & Marly nannofossil ooze \\
\hline $11-5,82$ & 111.32 & 1.59 & & 4 & Marly nannofossil ooze \\
\hline $11-6,49$ & 112.49 & 1.63 & 3.28 & $5 \mathrm{a}$ & Marly nannofossil ooze \\
\hline $11-6,112$ & 113.12 & 1.66 & & $5 a$ & Marly nannofossil ooze \\
\hline $12-1,77$ & 115.22 & 1.65 & & 5 a & Nannofossil ooze \\
\hline $12-2,41$ & 116.36 & 1.64 & 3.35 & $5 a$ & Nannofossil ooze \\
\hline $12-2,107$ & 117.02 & 1.64 & & $5 \mathrm{a}$ & Nannofossil ooze \\
\hline $12-3,34$ & 117.79 & 1.65 & & $5 \mathrm{a}$ & Nannofossil ooze \\
\hline $12-3,110$ & 118.55 & 1.66 & & $5 \mathrm{a}$ & Nannofossil ooze \\
\hline $12-4,46$ & 119.41 & 1.72 & 3.27 & $5 a$ & Nannofossil ooze \\
\hline $12-4,114$ & 120.09 & 1.68 & & $5 \mathrm{a}$ & Nannofossil ooze \\
\hline $15-6,38$ & 120.83 & 1.72 & & 5 a & Nannofossil ooze \\
\hline $12-5,105$ & 121.50 & 1.66 & & $5 \mathrm{a}$ & Nannofossil ooze \\
\hline $12-6,69$ & 122.64 & 1.68 & & $5 \mathrm{a}$ & Nannofossil ooze \\
\hline $13-1,79$ & 124.69 & 1.66 & & $5 \mathrm{a}$ & Nannofossil ooze \\
\hline $13-2,39$ & 125.79 & 1.65 & 3.47 & $5 \mathrm{a}$ & Nannofossil ooze \\
\hline $13-2,92$ & 126.32 & 1.39 & & $5 \mathrm{~b}$ & Nannofossil ooze \\
\hline $13-3,38$ & 127.28 & 1.36 & & $5 b$ & Nannofossil ooze \\
\hline $13-3,114$ & 128.04 & 1.58 & & $5 \mathrm{~b}$ & Nannofossil ooze \\
\hline $13-4,39$ & 128.79 & 1.59 & 3.09 & $5 \mathrm{~b}$ & Nannofossil ooze \\
\hline $13-4,110$ & 129.50 & 1.57 & & $5 \mathrm{~b}$ & Nannofossil ooze \\
\hline $13-5,42$ & 130.32 & 1.60 & & $5 b$ & Nannofossil ooze \\
\hline $13-5,107$ & 130.97 & 1.55 & & $5 \mathrm{~b}$ & Nannofossil ooze \\
\hline $13-6,47$ & 131.87 & 1.61 & 3.00 & $5 \mathrm{~b}$ & Nannofossil ooze \\
\hline $14-1,81$ & 133.81 & 1.60 & & 6 & Nannofossil ooze \\
\hline $14-2,44$ & 134.94 & 1.59 & & 6 & Nannofossil ooze \\
\hline $14-2,83$ & 135.33 & 1.59 & 3.00 & 6 & Nannofossil ooze \\
\hline $14-3,46$ & 136.46 & 1.63 & & 6 & Nannofossil ooze \\
\hline $14-3,68$ & 136.68 & 1.62 & & 6 & Nannofossil ooze \\
\hline $14-3,90$ & 136.90 & 1.65 & & 6 & Nannofossil ooze \\
\hline $14-4,36$ & 137.86 & 1.62 & 3.06 & 6 & Nannofossil ooze \\
\hline $14-4,120$ & 138.70 & 1.59 & & 6 & Nannofossil ooze \\
\hline $14-5,93$ & 139.93 & 1.72 & 3.60 & 7 & Marly nannofossil ooze \\
\hline $14-5,112$ & 140.12 & 1.70 & & 7 & Marly nannofossil ooze \\
\hline
\end{tabular}

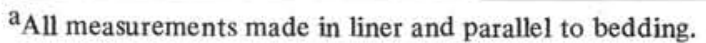

The porosity data obtained from the GRAPE scans are presented graphically with the visual core descriptions and core photos at the end of this chapter.

The porosity data from the "syringe" method yielded an average density of $1.75 \mathrm{~g} / \mathrm{cc}$ for sediments of Hole 390 and $1.70 \mathrm{~g} / \mathrm{cc}$ for those of Hole $390 \mathrm{~A}$. Average densities for each lithologic unit are given in Table 14.

Wet bulk density increases in sediments downhole and markedly increases between units $3 \mathrm{a}$ and $3 \mathrm{~b}, 4$ and $5 \mathrm{a}$ and 6 and 7.

Data from velocity, impedance, and "syringe", measurements (water content, porosity and density) are consistent with the identification of seismic reflectors at the boundaries between units 6 and 7 (unconformity between Albian and Campanian) and between units $3 a$ and $3 b$ (basal Eocene chert and ooze) and between $3 b$ and 4 (Paleocene/Danian).

\section{Vane Shear Strength}

Shipboard technicians made shear strength measurements on eight samples from the top 9 meters of Hole 390. The sediment is $22 \mathrm{~cm}$ of loose Mn-foraminifer "sand" overlying 8 meters of calcareous nannofossil ooze. Measurements were only made on the cohesive nannofossil ooze.
Torque was measured with a Wykeham-Farrance Vane Shear Device which was inserted parallel to bedding of the split cores. The device is equipped with a calibrated spring and the vane $(1 / 2$ by $1 / 2$ inch) was mechanically rotated at $89 \%$ min. Peak spring deflection and strain were recorded, and from these peak shear strength was determined $\left(\mathrm{g} / \mathrm{cm}^{2}\right)$. The vane was then rotated $360^{\circ}$ and the torque required to continue shear (remolded strength), as measured by the spring's deflection, was recorded. The sensitivity is expressed as the ratio between peak strength and remolded strength. These data are presented in Table 15 . The single measurement from unit 1 gave a peak shear strength of 32.2 $\mathrm{g} / \mathrm{cm}^{2}$ and remolded shear strength of $14.5 \mathrm{~g} / \mathrm{cm}^{2}$. Seven measurements from unit 2 yielded an average peak shear strength of $57.8 \mathrm{~g} / \mathrm{cm}^{2}$ and remolded shear strength of 22.5 $\mathrm{g} / \mathrm{cm}^{2}$.

\section{BIOSTRATIGRAPHY}

\section{Summary}

Sites 389 and 390 (Holes 390 and 390A) were drilled on the Blake Nose, a northeast-jutting spur of the Blake Plateau. The sedimentary sequence, rich in calcareous ooze, chalk, limestone, and variegated calcareous clays, was 
TABLE 10

Water Content, Porosity, and Wet Bulk Density, Site 390

\begin{tabular}{|c|c|c|c|c|c|c|}
\hline $\begin{array}{c}\text { Sample } \\
\text { (Interval in } \mathrm{cm} \text { ) }\end{array}$ & $\begin{array}{l}\text { Depth } \\
\text { in Hole } \\
(\mathrm{m})\end{array}$ & $\begin{array}{l}\text { Water } \\
\text { Content } \\
(\%)\end{array}$ & $\begin{array}{l}\text { Wet Bulk } \\
\text { Density } \\
(\mathrm{g} / \mathrm{cc})\end{array}$ & $\begin{array}{c}\text { Porosity } \\
(\%)\end{array}$ & $\begin{array}{l}\text { Lithologic } \\
\text { Unit }\end{array}$ & Lithology \\
\hline \multicolumn{7}{|l|}{ Hole 390} \\
\hline $\begin{array}{l}1-1,129.5 \\
1-2,68.5 \\
1-3,34.5 \\
1-3,38.5\end{array}$ & $\begin{array}{l}1.30 \\
2.19 \\
3.35 \\
3.38\end{array}$ & $\begin{array}{l}35.5 \\
35.0 \\
36.5 \\
39.8\end{array}$ & $\begin{array}{l}1.73 \\
1.72 \\
1.70 \\
1.60\end{array}$ & $\begin{array}{l}61.6 \\
60.2 \\
62.1 \\
63.6\end{array}$ & $\begin{array}{l}2 \\
2 \\
2 \\
2\end{array}$ & $\begin{array}{l}\text { Nannofossil ooze } \\
\text { Nannofossil ooze } \\
\text { Nannofossil ooze } \\
\text { Nannofossil ooze }\end{array}$ \\
\hline Section 3 averages & & 38.1 & 1.65 & 62.9 & & \\
\hline $\begin{array}{l}1-4,46.5 \\
1-5,38.5 \\
1-5,78.5\end{array}$ & $\begin{array}{l}4.97 \\
6.39 \\
6.79\end{array}$ & $\begin{array}{l}44.6 \\
36.4 \\
37.1\end{array}$ & $\begin{array}{l}1.52 \\
1.69 \\
1.68\end{array}$ & $\begin{array}{l}67.9 \\
61.4 \\
62.4\end{array}$ & $\begin{array}{l}2 \\
2 \\
2\end{array}$ & $\begin{array}{l}\text { Nannofossil ooze } \\
\text { Nannofossil ooze } \\
\text { Nannofossil ooze }\end{array}$ \\
\hline Section $S$ averages & & 36.7 & 1.69 & 61.9 & & \\
\hline $\begin{array}{l}1-6,55.5 \\
1-6,110.5\end{array}$ & $\begin{array}{l}8.06 \\
8.61\end{array}$ & $\begin{array}{l}44.4 \\
42.0\end{array}$ & $\begin{array}{l}1.53 \\
1.59\end{array}$ & $\begin{array}{l}67.9 \\
57.0\end{array}$ & 2 & $\begin{array}{l}\text { Nannofossil ooze } \\
\text { Nannofossil ooze }\end{array}$ \\
\hline Section 6 averages & & 43.2 & 1.56 & 67.5 & & \\
\hline Core 1 averages & & 39.0 & 1.64 & 63.8 & & \\
\hline $\begin{array}{l}2-1,136.5 \\
3-2,75.5 \\
3-3,59.5\end{array}$ & $\begin{array}{l}124.87 \\
135.26 \\
136.60\end{array}$ & $\begin{array}{l}22.5 \\
28.0 \\
20.2\end{array}$ & $\begin{array}{l}1.81 \\
1.90 \\
1.95\end{array}$ & $\begin{array}{l}40.8 \\
53.2 \\
39.4\end{array}$ & $\begin{array}{l}5 \mathrm{a} \\
7 \\
7\end{array}$ & $\begin{array}{l}\text { Marly nannofossil ooze } \\
\text { Clay with nannofossil ooze } \\
\text { Nannofossil clay }\end{array}$ \\
\hline Core 3 averages & & 24.1 & 1.93 & 46.3 & & \\
\hline $\begin{array}{l}4-2,54.5 \\
5-2,102.5\end{array}$ & $\begin{array}{l}144.55 \\
154.53\end{array}$ & $\begin{array}{l}26.5 \\
19.1\end{array}$ & $\begin{array}{l}1.78 \\
2.15\end{array}$ & $\begin{array}{l}47.1 \\
41.1\end{array}$ & $\begin{array}{l}7 \\
7\end{array}$ & $\begin{array}{l}\text { Marly nannofossil ooze } \\
\text { Nannofossil chalk }\end{array}$ \\
\hline $\begin{array}{l}2-1,110.5 \\
2-2,60.5\end{array}$ & $\begin{array}{l}20.11 \\
21.11\end{array}$ & $\begin{array}{l}50.5 \\
48.3\end{array}$ & $\begin{array}{l}1.48 \\
1.55\end{array}$ & $\begin{array}{l}74.8 \\
75.0\end{array}$ & $\begin{array}{l}2 \\
2\end{array}$ & $\begin{array}{l}\text { Siliceous nannofossil ooze } \\
\text { Siliceous nannofossil ooze }\end{array}$ \\
\hline Core 2 averages & & 49.4 & 1.52 & 74.9 & & \\
\hline $\begin{array}{l}3-2,89.5 \\
3-3,34.5 \\
3-4,82.5\end{array}$ & $\begin{array}{l}30.90 \\
31.85 \\
33.82\end{array}$ & $\begin{array}{l}44.8 \\
45.0 \\
48.8\end{array}$ & $\begin{array}{l}1.52 \\
1.52 \\
1.49\end{array}$ & $\begin{array}{l}68.0 \\
68.5 \\
72.7\end{array}$ & $\begin{array}{l}2 \\
2 \\
2\end{array}$ & $\begin{array}{l}\text { Siliceous nannofossil ooze } \\
\text { Siliceous nannofossil ooze } \\
\text { Siliceous nannofossil ooze }\end{array}$ \\
\hline Core 3 averages & & 46.2 & 1.51 & 69.7 & & \\
\hline $\begin{array}{l}4-1,49.5 \\
4-2,48.5 \\
4-3,49.5 \\
4-4,88.5 \\
4-5,48.5 \\
4-6,85.5\end{array}$ & $\begin{array}{l}38.90 \\
40.39 \\
41.90 \\
43.79 \\
44.89 \\
46.76\end{array}$ & $\begin{array}{l}45.8 \\
46.1 \\
44.1 \\
44.3 \\
46.1 \\
39.3\end{array}$ & $\begin{array}{l}1.49 \\
1.53 \\
1.54 \\
1.49 \\
1.50 \\
1.59\end{array}$ & $\begin{array}{l}68.5 \\
70.6 \\
68.0 \\
66.1 \\
69.2 \\
62.5\end{array}$ & $\begin{array}{l}2 \\
2 \\
2 \\
2 \\
2 \\
2\end{array}$ & $\begin{array}{l}\text { Siliceous nannofossil ooze and nannofossil chalk } \\
\text { Siliceous nannofossil ooze and nannofossil chalk } \\
\text { Siliceous nannofossil ooze and nannofossil chalk } \\
\text { Siliceous nannofossil ooze and nannofossil chalk } \\
\text { Siliceous nannofossil ooze and nannofossil chalk } \\
\text { Siliceous nannofossil ooze and nannofossil chalk }\end{array}$ \\
\hline Core 4 averages & & 44.3 & 1.53 & 67.5 & & \\
\hline $\begin{array}{l}5-1,83.5 \\
5-2,86.5 \\
5 \cdot 3,37.5 \\
5-4,124.5\end{array}$ & $\begin{array}{l}48.34 \\
49.87 \\
50.88 \\
53.25\end{array}$ & $\begin{array}{l}38.3 \\
40.2 \\
49.8 \\
51.0\end{array}$ & $\begin{array}{l}1.66 \\
1.63 \\
1.44 \\
1.47\end{array}$ & $\begin{array}{l}63.6 \\
65.6 \\
71.6 \\
74.7\end{array}$ & $\begin{array}{l}3 \mathrm{a} \\
3 \mathrm{a} \\
3 \mathrm{a} \\
3 \mathrm{a}\end{array}$ & $\begin{array}{l}\text { Foraminifer nannofossil ooze } \\
\text { Nannofossil chalk } \\
\text { Siliceous nannofossil ooze } \\
\text { Siliceous nannofossil ooze }\end{array}$ \\
\hline Core 5 averages & & 44.9 & 1.55 & 68.9 & & \\
\hline $\begin{array}{l}6 \cdot 1,44.5 \\
6-2,92.5 \\
6-3,120.5 \\
6-4,30.5 \\
6-5,103.5 \\
6-6,115.5\end{array}$ & $\begin{array}{l}57.85 \\
59.83 \\
61.61 \\
62.21 \\
64.44 \\
66.06\end{array}$ & $\begin{array}{l}37.7 \\
46.3 \\
47.9 \\
46.5 \\
47.4 \\
34.9\end{array}$ & $\begin{array}{l}1.66 \\
1.45 \\
1.51 \\
1.50 \\
1.50 \\
1.73\end{array}$ & $\begin{array}{l}62.5 \\
67.4 \\
72.4 \\
69.7 \\
71.2 \\
60.4\end{array}$ & $\begin{array}{l}3 \mathrm{a} \\
3 \mathrm{a} \\
3 \mathrm{a} \\
3 \mathrm{a} \\
3 \mathrm{a} \\
3 \mathrm{a}\end{array}$ & $\begin{array}{l}\text { Nannofossil ooze } \\
\text { Nannofossil ooze } \\
\text { Siliceous nannofossil ooze } \\
\text { Siliceous nannofossil ooze } \\
\text { Siliceous nannofossil ooze } \\
\text { Siliceous nannofossil ooze }\end{array}$ \\
\hline Core 6 averages & & 43.5 & 1.56 & 67.3 & & \\
\hline $\begin{array}{l}7-4,56.5 \\
8-2,86.5 \\
8-3,48.5 \\
8-4,56.5\end{array}$ & $\begin{array}{l}71.57 \\
78.37 \\
79.49 \\
81.07\end{array}$ & $\begin{array}{l}51.9 \\
34.9 \\
35.3 \\
33.0\end{array}$ & $\begin{array}{l}1.41 \\
1.70 \\
1.77 \\
1.72\end{array}$ & $\begin{array}{l}73.2 \\
59.5 \\
62.5 \\
56.7\end{array}$ & $\begin{array}{l}3 \mathrm{a} \\
3 \mathrm{~b} \\
3 \mathrm{~b} \\
3 \mathrm{~b}\end{array}$ & $\begin{array}{l}\text { Siliceous nannofossil ooze } \\
\text { Nannofossil ooze } \\
\text { Nannofossil ooze } \\
\text { Nannofossil ooze }\end{array}$ \\
\hline Core 8 averages & & 34.4 & 1.73 & 59.7 & & \\
\hline $\begin{array}{l}9-1,116.5 \\
10-1,64.5 \\
10-3,38.5 \\
10-5,107.5\end{array}$ & $\begin{array}{r}86.67 \\
96.05 \\
98.79 \\
102.48\end{array}$ & $\begin{array}{l}31.6 \\
27.4 \\
30.3 \\
30.2\end{array}$ & $\begin{array}{l}1.94 \\
1.88 \\
1.78 \\
1.82\end{array}$ & $\begin{array}{l}61.3 \\
51.8 \\
53.9 \\
54.9\end{array}$ & $\begin{array}{l}3 b \\
4 \\
4 \\
4\end{array}$ & $\begin{array}{l}\text { Zeolitic nannofossil ooze } \\
\text { Zeolitic marly nannofossil ooze } \\
\text { Zeoitic marly nannofossil ooze } \\
\text { Zeolitic marly nannofossil ooze }\end{array}$ \\
\hline Core 10 averages & & 29.3 & 1.83 & 53.5 & & \\
\hline $\begin{array}{l}11-2,72.5 \\
11-4,39.5 \\
11-6.49 .5\end{array}$ & $\begin{array}{l}106.72 \\
109.39 \\
112.50\end{array}$ & $\begin{array}{l}29.3 \\
29.1 \\
22.3\end{array}$ & $\begin{array}{l}1.80 \\
1.83 \\
2.01\end{array}$ & $\begin{array}{l}52.8 \\
53.3 \\
44.8\end{array}$ & $\begin{array}{l}4 \\
4 \\
5 \mathrm{a}\end{array}$ & $\begin{array}{l}\text { Nannofossil ooze } \\
\text { Marly nannofossil ooze } \\
\text { Marly nannofossil ooze }\end{array}$ \\
\hline Core 11 averages & & 26.9 & 1.88 & 50.3 & & \\
\hline $\begin{array}{l}12-2,41.5 \\
12-4,47.5 \\
12-6,59.5\end{array}$ & $\begin{array}{l}116.37 \\
119.43 \\
122.55\end{array}$ & $\begin{array}{l}23.7 \\
22.0 \\
23.3\end{array}$ & $\begin{array}{l}2.04 \\
1.90 \\
2.05\end{array}$ & $\begin{array}{l}48.4 \\
41.8 \\
47.7\end{array}$ & $\begin{array}{l}5 \mathrm{a} \\
5 \mathrm{a} \\
5 \mathrm{a}\end{array}$ & $\begin{array}{l}\text { Nannofossil ooze } \\
\text { Nannofossil ooze } \\
\text { Nannofossil ooze }\end{array}$ \\
\hline Core 12 averages & & 23.0 & 1.99 & 46.0 & & \\
\hline $\begin{array}{l}13-2,42.5 \\
13-4,40.5 \\
13-6,47.5\end{array}$ & $\begin{array}{l}125.83 \\
128.81 \\
131.88\end{array}$ & $\begin{array}{l}21.3 \\
25.2 \\
24.7\end{array}$ & $\begin{array}{l}2.10 \\
1.94 \\
1.86\end{array}$ & $\begin{array}{l}44.7 \\
48.8 \\
45.9\end{array}$ & $\begin{array}{l}5 b \\
5 b \\
5 b\end{array}$ & $\begin{array}{l}\text { Nannofossil ooze } \\
\text { Nannofossil ooze } \\
\text { Nannofossil ooze }\end{array}$ \\
\hline Core 13 averages & & 23.7 & 1.97 & 46.5 & & \\
\hline $\begin{array}{l}14-2,85.5 \\
14-4,37.5 \\
14-5,97.5\end{array}$ & $\begin{array}{l}135.36 \\
137.88 \\
139.97\end{array}$ & $\begin{array}{l}25.5 \\
25.8 \\
18.7\end{array}$ & $\begin{array}{l}1.89 \\
1.89 \\
2.09\end{array}$ & $\begin{array}{l}48.3 \\
48.9 \\
39.0\end{array}$ & $\begin{array}{l}6 \\
6 \\
7\end{array}$ & $\begin{array}{l}\text { Nannofossil ooze } \\
\text { Nannofossil ooze } \\
\text { Marly nannofossil ooze }\end{array}$ \\
\hline Core 14 averages & & 23.4 & 1.96 & 45.4 & & \\
\hline
\end{tabular}


TABLE 11

Average Sonic Velocities of Each Lithologic Unit, Site 390

\begin{tabular}{|c|c|c|c|c|c|c|}
\hline \multirow[b]{2}{*}{$\begin{array}{l}\text { Lithologic } \\
\text { Unit }\end{array}$} & \multicolumn{3}{|c|}{ Hole $390 \mathrm{~A}$} & \multicolumn{3}{|c|}{ Hole 390} \\
\hline & $\begin{array}{l}\text { Average } \\
\text { Velocity } \\
(\mathrm{km} / \mathrm{sec})\end{array}$ & $\begin{array}{c}\text { Range } \\
(\mathrm{km} / \mathrm{sec})\end{array}$ & $\begin{array}{c}\text { No. of } \\
\text { Measure- } \\
\text { ments }\end{array}$ & $\begin{array}{l}\text { Average } \\
\text { Velocity } \\
(\mathrm{km} / \mathrm{sec})\end{array}$ & $\begin{array}{c}\begin{array}{c}\text { Range } \\
(\mathrm{km} / \mathrm{sec})\end{array}\end{array}$ & $\begin{array}{c}\text { No. of } \\
\text { Measure- } \\
\text { ments }\end{array}$ \\
\hline 1 & \multicolumn{2}{|c|}{ no data } & & \multicolumn{2}{|c|}{ no data } & \\
\hline 2 & 1.52 & $1.49-1.59$ & 17 & 1.52 & $1.44-1.66$ & 8 \\
\hline $3 a$ & 1.53 & $1.51-1.55$ & 14 & & & \\
\hline $3 b$ & 1.57 & $1.52-1.61$ & 5 & & & \\
\hline 4 & 1.63 & $1.58-1.67$ & 18 & & & \\
\hline Sa & 1.67 & $1.63-1.72$ & 14 & & & \\
\hline $5 \mathrm{~b}$ & 1.53 & $1.36-1.61$ & 8 & & & \\
\hline 6 & 1.61 & $1.59-1.65$ & 8 & & & \\
\hline 7 & 1.71 & $1.71-1.72$ & 2 & 1.62 & $1.57-1.72$ & 8 \\
\hline 8 & & lata & & & & \\
\hline
\end{tabular}

TABLE 12

Average Water Content in Sediments of Each Lithologic Unit, Site 390

\begin{tabular}{|c|c|c|c|c|c|c|}
\hline \multirow[b]{2}{*}{$\begin{array}{l}\text { Lithologic } \\
\text { Unit }\end{array}$} & \multicolumn{3}{|c|}{ Hole $390 \mathrm{~A}$} & \multicolumn{3}{|c|}{ Hole 390} \\
\hline & $\begin{array}{c}\text { Average } \\
\text { Water } \\
\text { Content } \\
(\%)\end{array}$ & $\begin{array}{l}\text { Range } \\
(\%)\end{array}$ & $\begin{array}{l}\text { No. of } \\
\text { Measure- } \\
\text { ments }\end{array}$ & $\begin{array}{c}\text { Average } \\
\text { Water } \\
\text { Content } \\
(\%)\end{array}$ & $\begin{array}{l}\text { Range } \\
(\%)\end{array}$ & $\begin{array}{l}\text { No. of } \\
\text { Measure- } \\
\text { ments }\end{array}$ \\
\hline 2 & 45.7 & $39.3-50.5$ & 11 & 39.0 & $35.0-44.6$ & 9 \\
\hline $3 a$ & 44.7 & $37.7-51.9$ & 11 & & & \\
\hline $3 b$ & 33.7 & $31.6-35.3$ & 4 & & & \\
\hline 4 & 29.3 & $27.4-30.3$ & 5 & & & \\
\hline $5 \mathrm{a}$ & 22.8 & $22.0-23.7$ & 4 & 22.5 & & 1 \\
\hline $5 b$ & 23.7 & $21.3-25.2$ & 3 & & & \\
\hline 6 & 25.7 & $25.5-25.8$ & 2 & & & \\
\hline 7 & 18.7 & & 1 & 23.5 & $19.1-26.5$ & 4 \\
\hline
\end{tabular}

TABLE 13

Average Porosity in Sediments of Each Lithologic Unit, Site 390

\begin{tabular}{|c|c|c|c|c|c|c|}
\hline \multirow[b]{2}{*}{$\begin{array}{l}\text { Lithologic } \\
\text { Unit }\end{array}$} & \multicolumn{3}{|c|}{ Hole $390 \mathrm{~A}$} & \multicolumn{3}{|c|}{ Hole 390} \\
\hline & $\begin{array}{c}\text { Average } \\
\text { Porosity } \\
(\%)\end{array}$ & $\begin{array}{l}\text { Range } \\
(\%)\end{array}$ & $\begin{array}{l}\text { No. of } \\
\text { Measure- } \\
\text { ments }\end{array}$ & $\begin{array}{c}\text { Average } \\
\text { Porosity } \\
(\%)\end{array}$ & $\begin{array}{l}\text { Range } \\
(\%)\end{array}$ & $\begin{array}{l}\text { No. of } \\
\text { Measure- } \\
\text { ments }\end{array}$ \\
\hline 2 & 69.4 & $66.1-75.0$ & 11 & 63.8 & $60.2-67.9$ & 9 \\
\hline $3 a$ & 68.4 & $62.5-74.7$ & 11 & & & \\
\hline $3 b$ & 60.0 & $56.7-62.5$ & 4 & & & \\
\hline 4 & 53.3 & $51.6-54.9$ & 5 & & & \\
\hline $5 \mathrm{a}$ & 45.7 & $41.8-50.3$ & 4 & 40.8 & & 1 \\
\hline $5 b$ & 46.5 & $44.7-48.8$ & 3 & & & \\
\hline 6 & 48.6 & $48.3-48.9$ & 2 & & & \\
\hline 7 & 39.0 & & 1 & 45.2 & $39.4-53.2$ & 4 \\
\hline
\end{tabular}

TABLE 14

Average Wet Bulk Density of Sediments for Each Lithologic Unit, Site 390

\begin{tabular}{cccccccc}
\hline Lithologic & $\begin{array}{c}\text { Hensity } \\
\text { Unit }\end{array}$ & $\begin{array}{c}\text { Range } \\
(\mathrm{g} / \mathrm{cc})\end{array}$ & $\begin{array}{c}\text { No. of } \\
\text { Measure- } \\
\text { ments }\end{array}$ & $\begin{array}{c}\text { Density } \\
(\mathrm{g} / \mathrm{cc})\end{array}$ & $\begin{array}{c}\text { Range } \\
(\mathrm{g} / \mathrm{cc})\end{array}$ & $\begin{array}{c}\text { Measure- } \\
\text { ments }\end{array}$ \\
\hline 2 & 1.52 & $1.48-1.59$ & 11 & 1.64 & $1.52-1.73$ & 9 \\
3a & 1.54 & $1.42-1.73$ & 11 & & & \\
3b & 1.78 & $1.70-1.94$ & 4 & & & \\
4 & 1.82 & $1.78-1.88$ & 5 & & & 1 \\
$5 \mathrm{a}$ & 2.00 & $1.90-2.05$ & 4 & 1.81 & & \\
$5 \mathrm{~b}$ & 1.97 & $1.86-2.10$ & 3 & & & 4 \\
\hline 7 & 1.89 & $1.89-1.89$ & 2 & 1.96 & $1.78-2.15$ & 4 \\
\hline
\end{tabular}

continuously cored at this site. The sediments recovered (except a thin veneer of Quaternary sediments at the surface cored in the single core taken at Site 389 and top of 390-1-1) range from middle Eocene to Lower Cretaceous (Barremian). The entire sequence is especially rich in nannoplankton and foraminifers; abundant siliceous microfossils were found only in Eocene cores recovered at Hole 390A. The Eocene sediments cored at Hole 390A are fundamental to our understanding of siliceous microfossil biostratigraphy, as radiolarian zones can be directly correlated to the standard low latitude nannofossil and foraminiferal zonations. A summary of the paleontological results is presented in Figure 19.

\section{Tertiary}

Nannoplankton and foraminifers are abundant and generally well preserved throughout the Eocene and Paleocene sediments recovered from Hole 390 (Core 1) and Holes 390A (Cores 1 through 11, Section 5). The dominant lithology of these lower Tertiary sediments is nannofossil ooze, which is somewhat clayey in the lower Paleocene section.

Calcareous nannoplankton zones recognized between Cores 1 and 7 at Hole 390A range from the Marthasterites tribrachiatus (NP 12) to the Sphenolithus furcatolithoides ( $\sim$ NP 16) Zone, and correlate to the G. formosa (P.7) through G. lehneri (P.12) foraminifer zones (Figure 19). Core 390A-8 through Core 390A-11, Section 5 correspond to the $M$. inversus (NP 1) - D. mohleri (NP 7) nannofossil zones and to the G. eugubina (P.1) - G. pseudomenardii (P.4) foraminifer zones. On the basis of calcareous microfossils, the Eocene/Paleocene boundary is placed between Cores 7 and 8 at Hole 390A.

Radiolarians were found in the middle and lower Eocene sediments at Hole $390 \mathrm{~A}$. Cores 1 through 4 were placed in the Thyrsocyrtis triancantha Zone, Cores 5-2 through 6-5, the Phormocyrtis striata striata Zone; Cores 6-6 through 7-4, the Buryella clinata Zone and 7, CC the Bekoma bidartensis Zone. The micropaleontological analysis of the Tertiary sediments at Hole 390A shows that several nannoplankton and foraminifer zones are missing between Cores 7 and 8 and between Cores 7 and 8 and between Cores 8 and 9, corresponding, respectively, to the Eocene/Paleocene and upper and lower Paleocene boundaries (see Figure 20). The zones probably occur in the sample gaps between the cores.

\section{Tertiary/Cretaceous Boundary}

At Hole $390 \mathrm{~A}$, a continuously cored section penetrated the Tertiary/Cretaceous boundary. Analyses of the nannoplankton and foraminifer fauna place the boundary between 145 and $149 \mathrm{~cm}$ in Core 11, Section 5. At $145 \mathrm{~cm}$ in Section 5, the $M$. inversus (NP 1) nannoplankton zone and the $G$. eugubina (basal P.1) planktonic foraminifer zone are present, both of lowermost Paleocene. At $149 \mathrm{~cm}$, a smear slide indicates the first sample assigned to the upper Maestrichtian M. mura Zone. A small foraminifer residue at that depth suggests the presence of the $G$. contusa Zone (UC16).

Section $6,66-68 \mathrm{~cm}$ certainly belongs in Zone UC16. The A. mayaroensis Zone (UC17) is absent because of a small hiatus $\left(1-2 \times 10^{6} \mathrm{yr}\right)$ in which uppermost Maestrichtian sediments are missing.

The sediments are a slightly clayey nannofossil ooze, but a marked color change from light gray above to light bluish gray to greenish gray below marks the Tertiary/Cretaceous contact.

\section{Cretaceous}

Abundant and well preserved, Lower and Upper Cretaceous nannoplankton and foraminifers were recovered in sediments at Holes 390 (Cores 2-6) and 390A (Core 11, 


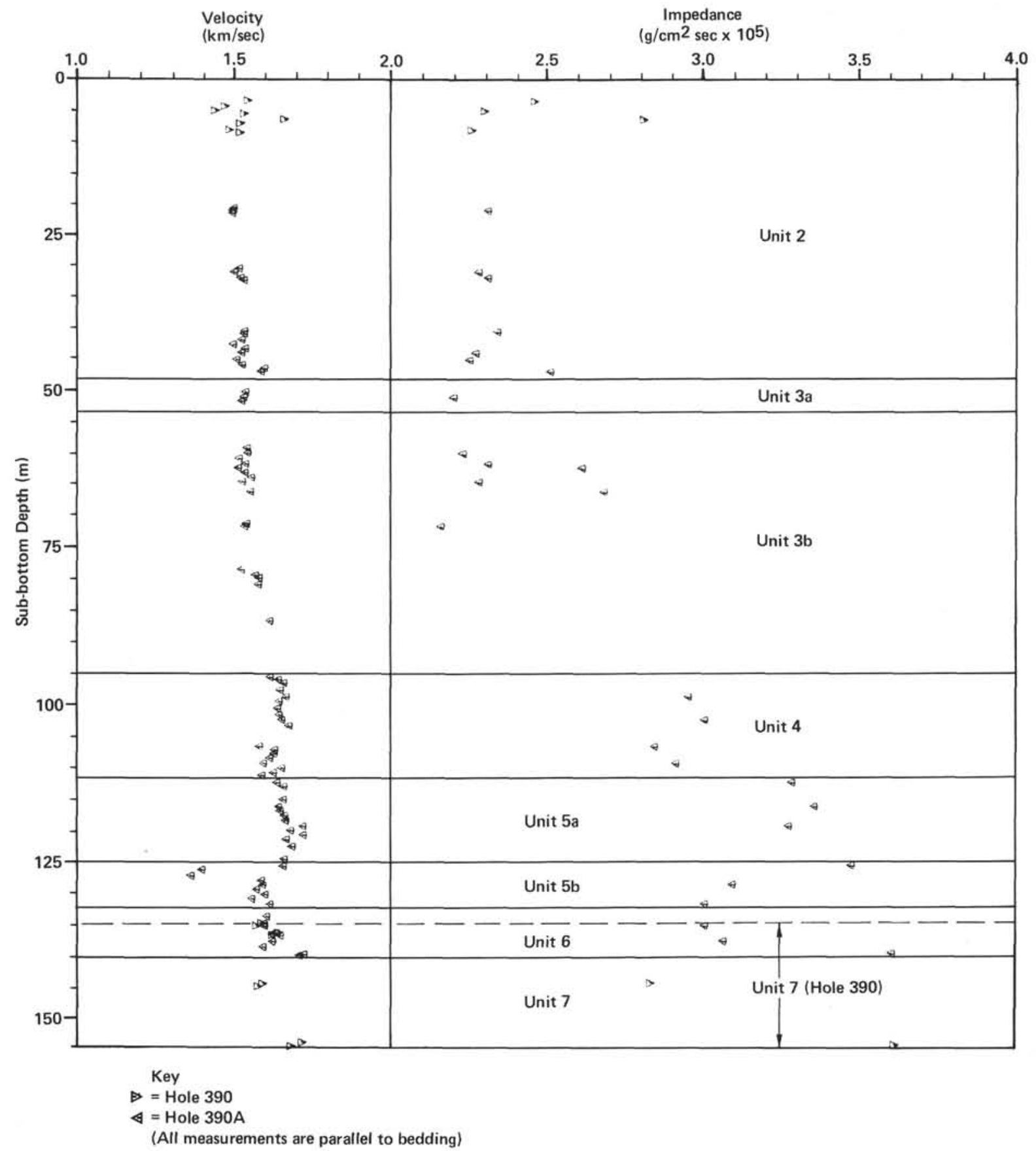

Figure 18. Velocity and impedance versus depth, Site 390.

TABLE 15

Shear Strength, Hole 390

\begin{tabular}{ccccc}
\multicolumn{5}{c}{ Shear Strength, Hole 390 } \\
\hline $\begin{array}{c}\text { Sample } \\
\text { (Interval in cm) }\end{array}$ & $\begin{array}{c}\text { Peak Shear } \\
\text { Strength } \\
\left(\mathrm{g} / \mathrm{cm}^{2}\right)\end{array}$ & $\begin{array}{c}\text { Remodeled } \\
\text { Strength } \\
\left(\mathrm{g} / \mathrm{cm}^{2}\right)\end{array}$ & $\begin{array}{c}\text { Sensitivity } \\
\text { Pk/Rmld. }\end{array}$ & $\begin{array}{c}\text { Lith. } \\
\text { Unit }\end{array}$ \\
\hline $1-1,118$ & 32.2 & 14.5 & 2.2 & 1 \\
$1-1,128$ & 53.9 & 14.5 & 3.7 & 2 \\
$1-1,138$ & 51.9 & 27.0 & 1.9 & 2 \\
$1-270$ & 70.5 & 29.0 & 2.4 & 2 \\
$1-3,41$ & 53.9 & 18.7 & 2.9 & 2 \\
$1-4,49$ & 24.9 & 11.4 & 2.2 & 2 \\
$1-5,79$ & 68.5 & 29.4 & 2.8 & 2 \\
$1-6,110$ & 80.9 & 32.2 & 2.5 & 2 \\
\hline
\end{tabular}




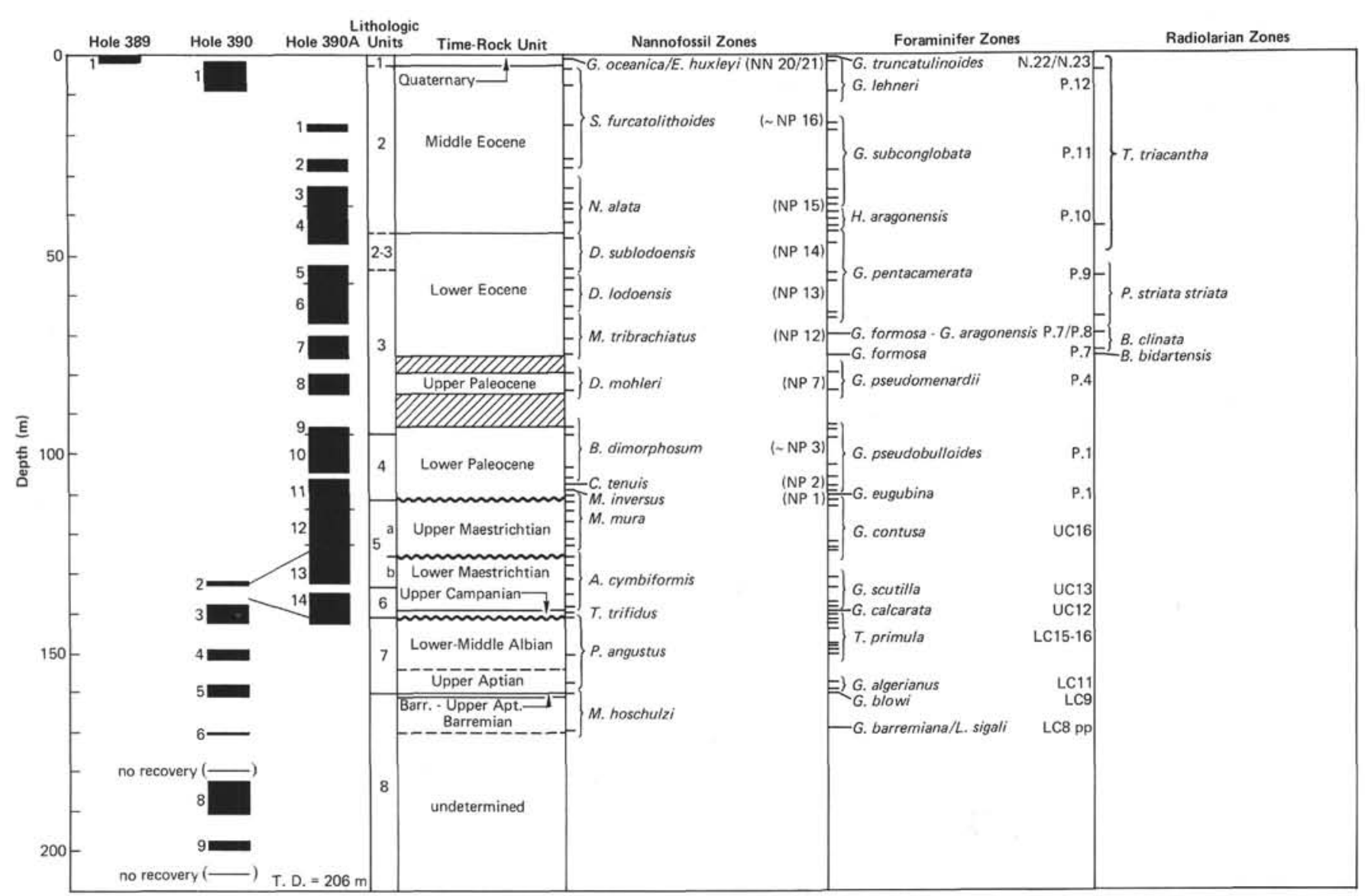

Figure 19. Biostratigraphic summary, Holes 389, 390, and 390A, Blake Nose.

Section 5 to Core 14). The composite lithologic sequence constructed at these holes includes Maestrichtian to Aptian nannofossil ooze, chalk, and calcareous clay, and Barremian limestone.

Lower to lower upper Maestrichtian sediments, which include the $M$. mura and $A$. cymbiformis nannofossil and $G$. contusa (UC16) and G. scutilla (UC13) foraminifer zones, were recovered between Cores 11 , Section 5 to Core 14, Section 4 at Hole 390A and in Core 2 at Hole 390. The $L$. quadratus nannoplankton zone and UC14-15 foraminifer zones are missing which may correspond to a "middle", Maestrichtian hiatus in 390A Core 13, between Sections 1 and 2 where there is a marked color change.

Upper Campanian sediments consisting of a nannofossil ooze which is appreciably firmer than any overlying ooze were recovered at the base of Core 14 at Hole 390A, but not at the same depth in Hole 390, probably owing to poor recovery in Core 2. The $T$. trifidus nannoplankton and $G$. calcarata (UC12) foraminifer zones are present in this narrow interval.

Middle Albian-upper Aptian sediments at Hole 390 consist of brown, red, and white variegated clays (Core 3 to Core 5, Section 2). Only the $P$. angustus nannoplankton zone was recognized in these cores (Figure 19), but it could be subdivided into two zones on the basis of the planktonic foraminifer $G$. algerianus, (LC11) and $T$. primula (LC15-16) Zones. The hiatus between Upper Campanian and Albian sediments, shown in Figure 24, must represent at least 30 million years.
The basal sediments at Hole 390 consist of Barremian-lower Aptian calcareous clay and shallow water limestone (see Figure 19). The $M$. hoschulzi nannofossil zone and the $G$. blowi (LC9) planktonic foraminifer zone was recognized in the core-catcher sample of Core 5, dating this sample as Barremian-lower Aptian. Core 6 contains a Barremian shallow marine foraminifer assemblage and the Barremian $M$. hoschulzi nannoplankton zone. In contrast to this, the overlying Aptian through middle Eocene microfossil assemblages are indicative of a deep marine environment.

\section{Foraminifers}

Rich and well preserved foraminifer assemblages were recovered from Site 389 and the two holes at Site 390. We saw little or no sign of dissolutions of tests. Fifty-three samples were studied encompassing assemblages ranging in age from Barremian to late Albian, late Campanian to middle Eocene and Quaternary (see Figures 19 and 20). The lower Cenozoic Zones are after Stainforth et al. (1975). For the upper Cretaceous, we used van Hinte's (1976) zonal scheme in conjunction with zonations of Bolli (1966) and Cita and Gartner (1971). The Lower Cretaceous zonal scheme follows van Hinte (1976) in combination with data on the ages of benthic species by several authors, including Bartenstein et al. (1957, 1966) Bartenstein and Bolli (1973), Simon and Bartenstein (1962) and Bartenstein (1976). Details of the zonal schemes are presented in the introduction to this volume. 


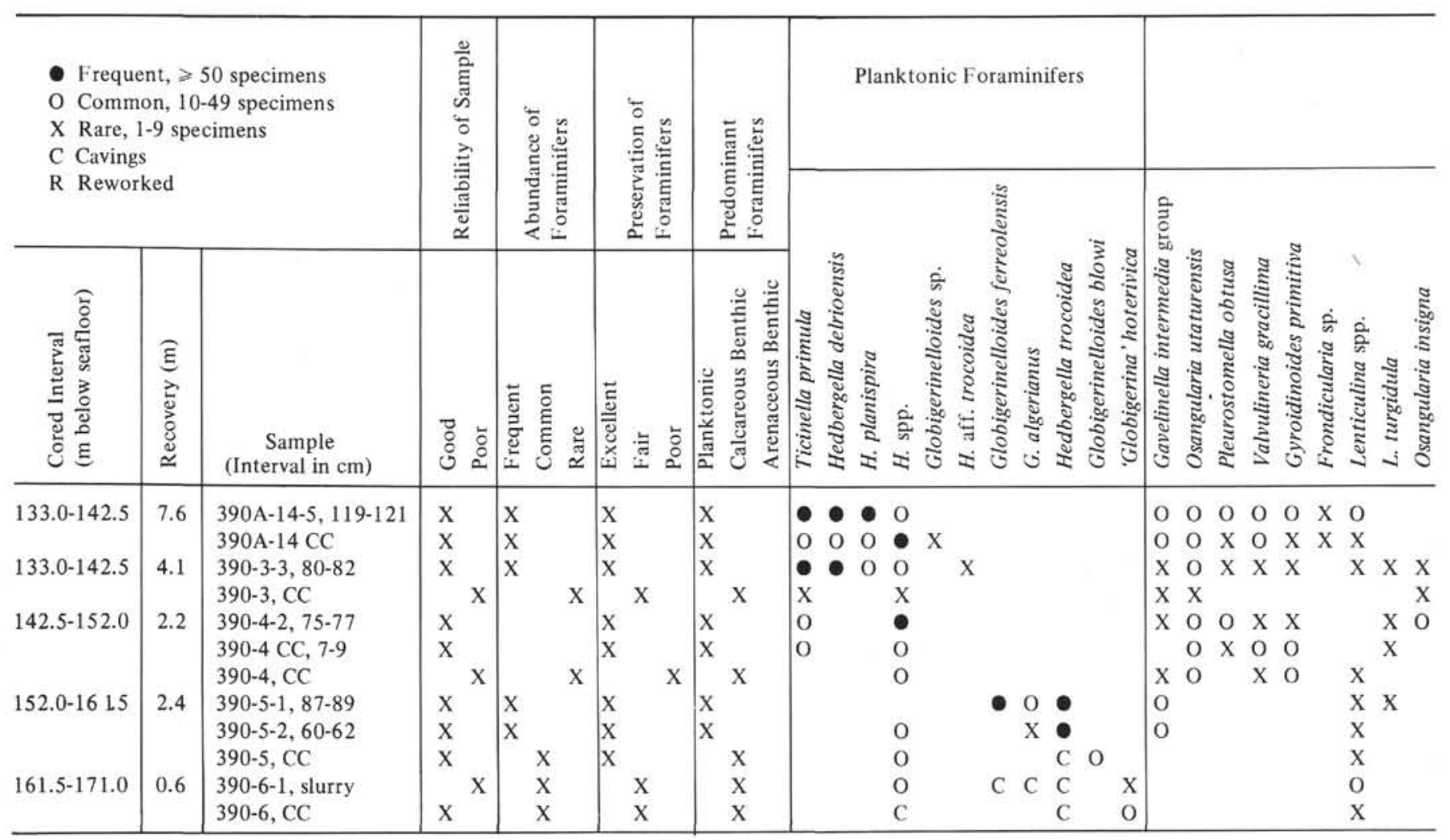

Figure 20. Distribution and biostratigraphy of Lower Cretaceous foraminifers at Site 390.

\section{Upper Cenozoic}

Sample 389-1-1, top; 389-1, CC. Globorotalia truncatulinoides Zone (N22/N23)

Sample 390-1-1, 100-102 cm. Quaternary

Samples are from a surface veneer of foraminifer sand rich in planktonic foraminifers and manganese nodules. The tests are excellently preserved and show no signs of dissolution, as would be expected at this relatively shallow water depth of approximately $2.6 \mathrm{~km}$. Some tests especially some of the reworked Neogene taxa are coated with manganese.

Globorotalia truncatulinoides, $G$. inflata, $G$. crassaformis, G. menardii, G. tumida (including var. flexuosa), G. hirsuta, Sphaeroidinella dehiscens excavata, Globigerinoides ruber (pink var.), G. extremus, G. trilobus, G. fistulosus, G. conglobatus, Globoquadrina dutertrei, ?Sphaeroidinella rutschi, Pulleniatina obliquiloculata, Hastigerina aequilateralis. Some deep water benthic species are Cibicides wuellerstorfi, Eggerella sp., and Cyclammina aff. cancellata.

Reworked Neogene species are Globoquadrina altispira, Globigerina nepenthes, and Globorotalia margaritae; Globorotalia spinulosa has been reworked from middle Eocene sediments; Globotruncana fornicata, G. rosetta, and G. stuarti occur in Campanian to Maestrichtian strata. Only a few specimens of these reworked taxa are present.

\section{Early Cenozoic}

Excellently preserved planktonic foraminifers were abundant in most of the samples along with a very few benthic specimens. Eight zones were recognized (Table 16). Several washed residues consisted almost completely of radiolarians and diatoms including Sample 390A-2, CC; 4-4, 101-103 cm; 6-2, 104-106 cm; 6-3, 108-110 cm; 6-4, $117-119 \mathrm{~cm} ; 7-4,124-126 \mathrm{~cm}$.

Samples 390-1-2, 48-50 cm and 1, CC. Globorotalia lehneri Zone (P.12), middle Eocene

Hantkenina mexicana-dumblei group, Globorotalia lehneri, G. bulbrooki group, G. spinulosa, G. centralis, Globigerina frontosa, Globigerinatheka subconglobata, Truncorotaloides topilensis, Pseudohastigerina micra. A few benthic specimens of the species Vulvulina spinosa, Siphonodosaria abyssorum, and Bulimina jarvisi (determinations following Douglas, 1974), Bulimina sp., Eponides sp., Cibicides sp.; also some ostracode specimens.

Samples 390A-1-1, 101-103 cm; 1, CC; 2, CC. Globigerinatheka subconglobata Zone (P.11)

Samples 3-2, 105-107 cm; 3-3, 93-95 cm; 3, CC. middle Eocene

The following species occur in their highest stratigraphic level in these samples; Globorotalia aragonensis, $G$. broedermanni, Globigerina higginsi. Also present are Globigerina senni, $G$. linaperta, $G$. bolivariana, Globigerinatheka index, Truncorotaloides rohri, and all of the planktonic species listed for the overlying Zone P.12.

Some specimens of Catapsydrax echinatus, which according to Stainforth et al. (1975) does not occur below Zone P.12, occur in Sample 3-2, 105-107 cm.

R. C. Tjalsma (Woods Hole Oceanographic Institution) kindly identified the following benthic species; Cibicidoides 


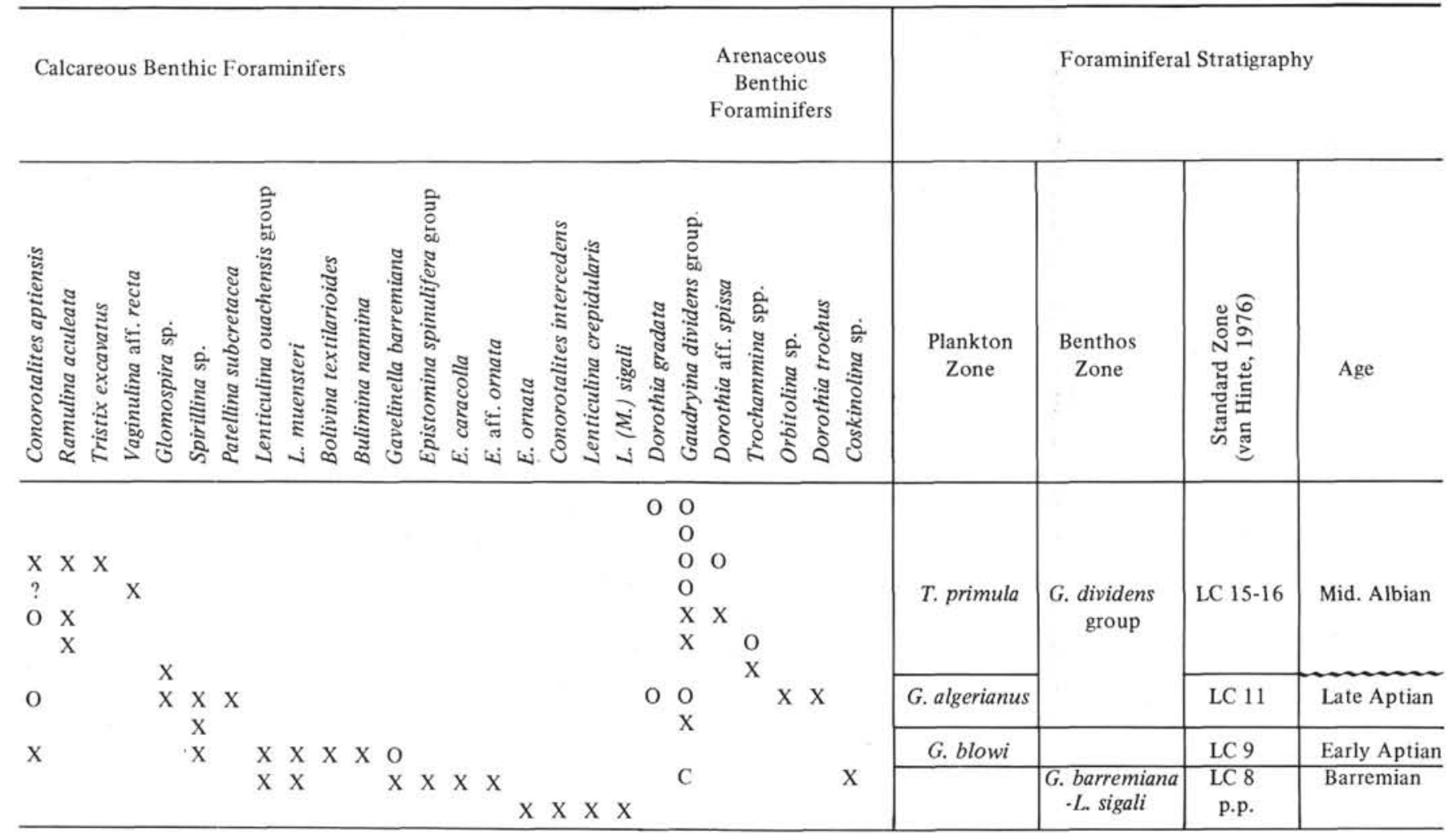

Figure 20. Continued.

subspinata, Bulimina semicostata, Cassidulina sublogobsa, Vulvulina spinosa, Pullenia quinqueloba, Siphonodosaria abyssorum, Nuttalides truempyi, Oridoralis umbonatus.

Samples 390A-4-2, 106-108 cm; 4-3, 100-102 cm; 4-5, 101-103 cm. Hantkenina aragonensis Zone (P.10), middle Eocene

No Globorotalia lehneri, and only a few specimens of Globigerinatheka subconglobata are present. Other species present include Globorotalia broedermanni, G. spinulosa, $G$. bulbrooki group (incl. $G$. aff. rotundimarginata and $G$. densa), G. aragonensis. G. centralis (rare), Hantkenina dumblei-mexicana group (rare), Globigerina senni, $G$. frontosa, G. higginsi, Truncorotaloides sp.

Samples 390A-4-6, 127-129 cm; 4, CC; 5-3, 109-111 cm; 6-4, 117-119 cm; 6-6, 123-125 cm; 6, CC. Globorotalia pentacamerata Zone (P.9), lower Eocene

Species not found in overlying samples include Globorotalia pentacamerata (some specimens with supplementary apertures), G. caucasica, G. quetra (with supplementary apertures), G. caucasica, G. quetra (with supplementary apertures), Globigerina soldadoensis, $G$. inaequispira, Pseudohastigerina wilcoxensis.

Globorotalia aff. spinolosa, G. bulbrooki group, G. aragonensis, Globigerina higginsi, $G$. senni, $G$. bolivariana, G. frontosa, Pseudohastigerina wilcoxensis are also present. The presence of a specimen of Globigerinatheka sp. in Sample 390A, 4-6, $127-129 \mathrm{~cm}$ is probably a result of mechanical contamination.
Benthos include Nuttalides truempyi, Bulimina sp., Cibicides sp.

Sample 390A-7-3, 134-136 cm. Globorotalia formosa formosa-Globorotalia aragonensis zones (P.7-P.8), lower Eocene

The stratigraphically highest occurrence of Globorotalia formosa group, G. pseudotopilensis and G. lensiformis; also present are $G$. aff. caucasica, $G$. aragonensis, $G$. pentacamerata, $G$. quetra, Globigerina senni, $G$. soldadoensis. No Globigerina higginsi or G. frontosa.

Sample 390A-7, CC. Globorotalia formosa formosa Zone (P.7), lower Eocene

Globorotalia formosa group, $G$. quetra, $G$. pseudotopilensis, Globigerina soldadoensis; Globotruncana contusa is reworked from Maestrichtian strata.

The top of the lowermost Paleocene-Eocene Zones P.5-P. 6 were not recognized, but might be present between Cores 7 and 8 .

Sample 390A-8-1, 139-140 cm; 8, CC; 8-3, 111-113 cm. Globorotalia pseudomenardii Zone, (P.4), upper Paleocene

Rich in Globorotalia pseudomenardii and $G$. velascoensis; also present are $G$. angulata, Globigerina triloculinoides, and $G$. nitida.

R. C. Tjalsma (Woods Hole Oceanographic Institution) kindly identified the following benthic forms: Aragonia velascoensis, Bolivinoides delicatulus, Bulimina trinitatensis, Dorothia trochoides, Gavelinella 
TABLE 16

Cretaceous and Lower Cenozoic Planktonic Foraminifer Zones in Holes 390 and 390A

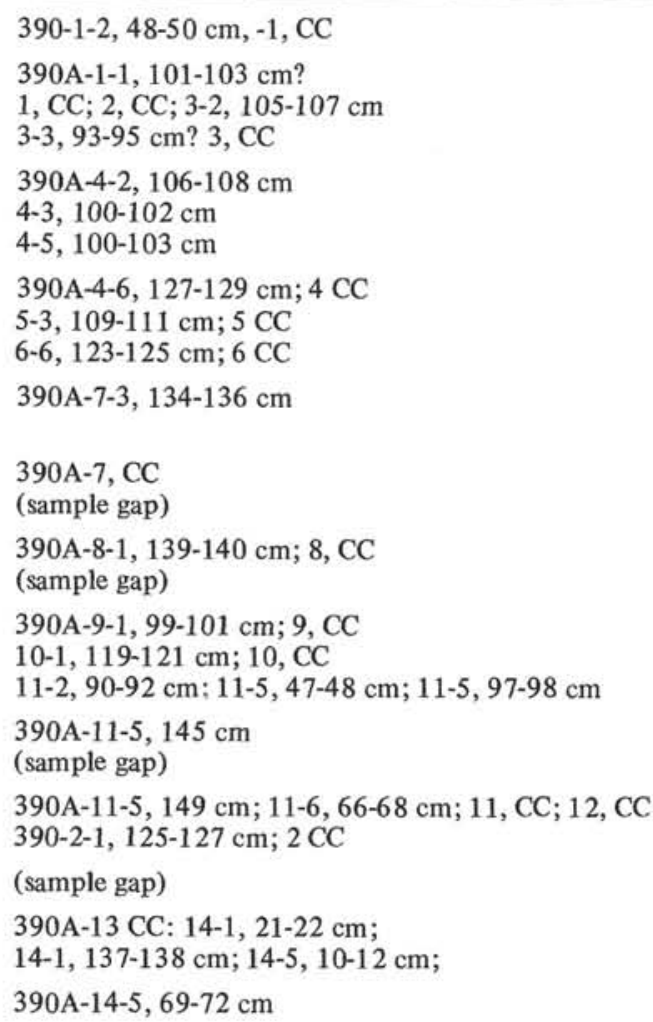

Globorotalia lehneri Zone P.12, middle Eocene

Globigerinatheka subconglobata Zone P.11, middle Eocene

Hantkenina aragonensis Zone P.10, middle Eocene

Globorotalia pentacamerata Zone P.9, lower Eocene

\begin{abstract}
Globorotalia formosa formosa-Globorotalia aragonensis Zones P.7-P.8, lower Eocene

Globorotalia formosa formosa Zone P.7, lower Eocene Uppermost Paleocene-lowermost Eocene (P.5, P.6) hiatus

Globorotalia pseudomenardii Zone P.4, upper Paleocene Middle Paleocene hiatus P.2/P.3 (? sample gap)

Globorotalia pseudobulloides Zone P.1, lower Paleocene
\end{abstract}

Globigerina eugubina Zone P.1, lowermost Paleocene Uppermost Maestrichtian hiatus, UC17

Globotruncana contusa Zone, UC16, lower upper

Maestrichtian

"middle" Maestrichtian hiatus, UC14, 15

Globotruncana scutilla Zone, UC13

Lower Maestrichtian

Globotruncana calcarata Zone, UC12

Upper Campanian beccariiformis, Gyroidinoides spp., Lenticulina velascoensis, Neoflabellina semireticulata, Nuttallides truempyi, Oridorsalis spp., O. umbonatus, Osangularia velascoensis, Nodosaria monile, Pullenia coryelli, Pyramidina sp., Tritaxia cf. globulifera, $T$. sp.

Zones P.2-P.3 of middle Paleocene sediments were not recognized but might be present between Cores 8 and 9 .

Samples 390A-9-1, 99-101 cm; 9, CC; 10-1, 119-121 cm; 10, CC; $11-2,90-92 \mathrm{~cm} ; 11-5,47-48 \mathrm{~cm} ; 11-5,97-98$ $\mathrm{cm}$. Globorotalia pseudobulloides Zone (P.1), lower Paleocene

Rich, low diversity planktonic assemblage with Globorotalia pseudobulloides, G. compressa, Globigerina triloculinoides, G. daubjergensis (relatively rare), Chiloguembelina spp. Some benthic species.

Sample 390A-11-5, $145 \mathrm{~cm}$. Globigerina eugubina Zone (P.1), lowermost Paleocene

We found evidence of the G. eugubina Zone at $145 \mathrm{~cm}$ (determination by R. R. Schmidt following Krasheninnikov and Hoskin, 1973), with Globigerina eugubina, G. fringa, G. minutula, Chiloguembelina taurica, Ch. spp., small Globigerina spp.

The Cretaceous/Tertiary contact occurs in Section 390A-11-5 between 145 and $149 \mathrm{~cm}$ where the nannofossil ooze changes from light gray above to light bluish gray to greenish gray below the contact. The stratigraphically highest occurrence of Globotruncana probably belonging in the $G$. contusa Zone (UC16) is at $149 \mathrm{~cm}$. We found no evidence of the Abathomphalus mayaroensis zone (UC17); even a large sample from 11-6, 66-69 $\mathrm{cm}$ yielded no $A$. mayaroensis. We interpret this absence to be the result of a hiatus in sedimentation of about $1-2 \times 10^{6} \mathrm{yr}$, during earliest Maestrichtian time.

\section{Upper Cretaceous}

We recognize three planktonic foraminifer zones in the Upper Cretaceous sediments of Holes 390 and 390A (see Table 14).

Samples 390-2-1, 125-127 cm; 2, CC and 390A-11-6, 66-68 $\mathrm{cm} ; 11, \mathrm{CC} ; 12$, CC. Globotruncana contusa Zone (UC16), lower upper Maestrichtian

Rich in excellently preserved planktonic foraminifers, virtually no benthic foraminifers. Globotruncana arca, $G$. contusa, G. stuarti, G. stuartiformis, G. gansseri (rare), G. fornicata (only in Sample 2, CC), G. linneiana group, $G$. conica, G. gagnebini, Globotruncanella havanensis, $G$. havanensis-intermedia, Globigerinelloides messinae, G. subcarinatus, Planoglobulina multicamerata, Pseudoguembelina excolata, Racemiguembelina fructicosa, Pseudotextularia elegans, Rugoglobigerina rotundata, Schackoina multispina, Hedbergella spp., Heterohelix spp.

The assemblage is that of the Globotruncana contusa Zone (UC16) of van Hinte (1976) and the broader G. gansseri Zone of Bolli (1966). Because UC13 is present in Sample 390A-13, CC (see below), the intermediate Zones UC14 and $\mathrm{UC} 15$ may be missing. This is consistent with the presence of the $M$. mura nannoplankton zone as low as Section $390 \mathrm{~A}-13-1$ and the $A$. cymbiformis nannoplankton zone as high as Section 390A-13-2. An intermediate $L$. quadratus 
nannoplankton zone sensu Martini, 1976, which approximately correlates to zones UC14 and UC15, seems to be absent, which corresponds with a "middle" Maestrichtian hiatus in Core 390A-13 between Sections 1 and 2 .

Samples 390A-13, CC; $14-1,21-22 \mathrm{~cm} ; 14-1,137-138 \mathrm{~cm}$; $14-5,10-12 \mathrm{~cm}$. Globotruncana scutilla Zone (UC13), lower Maestrichtian

Globotruncana linneiana group (incl. tricarinata), $G$. arca, G. stuartiformis, G. falsostuarti, G. conica, $G$. fornicata, (flatter test than in the samples of the $G$. gansseri Zone), Planoglobulina multicamerata. Benthic foraminifers are virtually absent.

The G. scutilla Zone (UC13) of van Hinte (1976) corresponds to the $G$. tricarinata Zone of Bolli (1966) and the $G$. arca Zone of Cita and Gartner (1971).

Sample 390A-14-5, 69-72 cm. Globotruncana calcarata Zone (UC12), upper Campanian

Globotruncana calcarata, G. linneiana group, G. arca, G. fornicata, G. conica, G. stuartiformis, Rugoglobigerina rugosa. Some planktonic specimens are coated with "iron" oxide, which may have been caused by some erosion and/or exposure at the contact with the immediately underlying Albian variegated clayey nannofossil ooze.

\section{Lower Cretaceous}

We found a mixture of species belonging in $\mathrm{UC} 13$ and the Albian Ticinella primula Zone (UC15) in Samples 390-3-1, 135-137 cm, 3-2, 61-63 cm, and 3-2, bottom. The mixture probably resulted from inclusion of cavings from up hole during drilling operations.

Samples 390A-14-5, 119-121 cm; 14, CC; 390-3-3, 80-82 $\mathrm{cm} ; 3, \mathrm{CC} ; 390-4-2,75-77 \mathrm{~cm} ; 4, \mathrm{CC}, 7-9 \mathrm{~cm} ; 4$, CC. Ticinella primula Zone, (LC15-16), middle Albian.

Ticinella primula, Hedbergella delrioensis, $H$. planispira, $H$. aff. trocoidea, Globigerinelloides sp., Gavelinella intermedia group, Osangularia utaturensis, $O$. insigna, Pleurostomella obtusa, Valvulineria gracillima, Conorotalites aptiensis, Ramulina aculeata, Vaginulina aff. recta, Glomospira sp., Dorothia gradata, Gaudryina dividens group, Dorothia aff. spissa, Trochammina spp.

Planktonic foraminifers comprise up to 90 per cent of the fauna; Ticinella primula is especially common.

Samples 390-5-1, 87-89 cm; 5-2, 60-62 cm. Globigerinelloides algerianus Zone, upper Aptian (LC11)

Globigerinelloides algerianus, G. ferreolensis, Hedbergella trocoidea, $H$. spp., Gavelinella intermedia group, Conorotalites aptiensis, Glomospira sp., Spirillina sp., Dorothia gradata, Gaudryina dividens group, Dorothia trochus, Orbitolina sp.

Planktonic foraminifers comprise up to 80 per cent of the fauna. Hedbergella trocoidea is especially common. The Orbitolina specimen probably is redeposited from shallower water, together with many echinoid-holothuroid fragments.

Sample 390-5, CC. Globigerinelloides blowi Zone (LC9), lower Aptian

Globigerinelloides blowi (common), Hedbergella spp., Conorotalites aptiensis, Spirillina sp., Lenticulina ouachensis group, L. muensteri, Bolivina textilarioides, Bulimina nanina, Gavelinella barremiana (common).

The presence of Hedbergella trocoidea in this and underlying samples with a preservation identical to that of the specimens in the overlying upper Aptian beds is probably a result of mechanical contamination (i.e., downhole caving).

Workers do not agree on the stratigraphic range of Gavelinella barremiana. According to Michael (1966) the species s.s. is of middle-late Barremian age (cf. van Hinte, 1976), but as a variant of $G$. intermedia morphologically similar specimens persisted into Aptian time. Bartenstein's (1976) cosmopolitan benthos stratigraphy shows a middle Barremian-early Aptian range. Sample $390-5, \mathrm{CC}$ is one out of 24 specimens intermediate between $G$. barremiana and $G$. intermedia, the other specimens show the typical $G$. barremiana morphology.

The sediments are assigned to the lower Aptian on the basis of the presence of Globigerinelloides blowi; the core-catcher sample could, in fact, contain Barremian-lower Aptian sediments. Except for $G$. barremiana, however Barremian species from the underlying samples are missing.

Sample 390-6-1 (slurry); 6, CC. Gavelinella barremiana-Lenticulina (M.) sigali Zone (LC8 pp.), Barremian

"Globigerina" hoterivica, Lenticulina ouachensis group, E. caracolla, E. aff. ornata, E. ornata, Conorotalites intercedens, Lenticulina crepidularis, L. (Marginulopsis) sigali, Coskinolina sp., and Trocholina sp. and Lingulina sp. (seen in thin section).

This is most likely Barremian assemblage which has been grouped in the informal Gavelinella barremiana-Lenticulina sigali Zone. It corresponds, in part, to Zone LC8 (van Hinte, 1976).

Specimens of Gaudryina dividens, Hedbergella trocoidea, Globigerinelloides algerianus, and $G$. ferreolensis are displaced from cavings; the same may be true for some tiny, indeterminate Hedbergella specimens.

The in situ foraminifer assemblage has relatively few specimens and is largely composed of benthic foraminifers including many lenticulinids. This assemblage, the presence of bryozoans, pelecypods, sponge or coral fragments, and crinoid stems, together with the limestone lithology, suggest deposition in a shallow-water environment.

Samples 390-8, CC; 9, CC. No in situ foraminifers

These samples contain some limestone spheres which are also present in Sample 390-6-1 (slurry) and 390-6, CC. Initially, we thought that they might be calcisphaerulids. H. M. Bolli (Zurich) kindly studied some specimens and determined that they are not calcisphaerulids, but are tiny limestone concretions. Most, or all of them are compact, around $200 \mu \mathrm{m}$ in diameter and in part built of nannoconids and possibly other nannofossils.

\section{Nannoplankton}

Only one core was recovered at Site 389. A sample from the muddy sand at the top of this artificially graded core (389-1, 101) contains a mixed flora of nannoplankton. A late Quaternary species assemblage indicates the presence of the combined Gephyrocapsa oceanica/Emiliania huxleyi zonal interval (NN 20/21). A wide variety of well preserved Upper 
Cretaceous reworked species is present, in addition to more rare middle Miocene-Pliocene specimens. The displaced Upper Cretaceous and middle Miocene-Pliocene assemblages were probably winnowed from subsurface outcrops in the vicinity and redeposited by surface currents.

Abundant and generally well preserved middle Eocene to Barremian nannofossils are present in Holes 390 and 390A. A large unconformity is documented between upper Campanian and lower Albian sediments in Section 390A-14-5. The Tertiary-Cretaceous boundary is in the lower part of Section 390A-11-5 (between 145 and $149 \mathrm{~cm}$ ).

\section{Eocene}

Cores 390-1 and 390A-1 through 390A-7 contain middle to lower Eocene nannofossil ooze. Nannofossils are moderately well preserved and are abundant in these cores. A succession of zones is recognized in this interval that corresponds to standard nannofossil Zones NP 12-NP 16.

Samples in Cores 390-1 and 390A-1 and -2 are assigned to the middle Eocene Sphenolithus furcatolithoides Zone (NP 16). Samples in Core 390A-3 are assigned to the middle Eocene Nannotetrina alata total-range zone (NP 15). These two zones are modifications of the standard zonation of Martini (1971); Rhabdosphaera gladius Locker, which defines the boundary between the standard Zones NP 15 and NP 16, was not found.

The interval between Samples 390A-4-6, $130 \mathrm{~cm}$ and $390 \mathrm{~A}-5-2,120 \mathrm{~cm}$ definitely is in the middle/lower Eocene Discoaster sublodoensis Zone (NP 14). Samples 390A-5-4, $126 \mathrm{~cm}$; 390A-6-2, $107 \mathrm{~cm}$; and 390A-6-4, $120 \mathrm{~cm}$ are assigned to the underlying lower Eocene Discoaster lodoensis Zone (NP 14). The remainder of Core 390A-6 and Core 390A-7 belong to the lower Eocene Marthasterites tribrachiatus Zone (NP 12).

\section{Paleocene}

Abundant, moderately well preserved nannofossils are present in the Paleocene nannofossil ooze of Hole 390A, Core 8 to Core $11-5,145 \mathrm{~cm}$. Reworked Upper Cretaceous species are present in all samples studied from the Paleocene sediments. Thoracosphaera species are significantly more abundant than in the overlying sediments.

All samples in Core 8 fall in the lower Paleocene Discoaster mohleri Zone (NP 7). The uppermost Paleocene and lowermost Eocene interval, zones NP 8 through NP 11, was not sampled at Hole $390 \mathrm{~A}$. It may be missing or simply not sampled, as recovery was incomplete in Cores 7 and 8 . Similarly, recovery was not complete in Cores 8 and 9 and the unsampled nannofossil Zones NP 4-NP 6 may or may not be represented in the middle Paleocene portion of the sequence.

The interval between Cores 390A-9 to 390A-11-5, $145 \mathrm{~cm}$ is referred to the Danian (early Paleocene) zones, corresponding to NP 1-NP 3. Cores 390A-9, -10, and the top of $390 \mathrm{~A}-11$ (390A-11-1, 137) are assigned to the Biscutum dimorphosum Zone, which is approximately equivalent to NP 3. The presence of Chiasmolithus danicus could not be confirmed in this sequence. The Cruciplacolithus tenuis Zone (NP 2) is recognized in the sample interval 390A-11-2, $93 \mathrm{~cm}$ to $390 \mathrm{~A}-11-5,35 \mathrm{~cm}$. The Markalius inversus Zone (NP 1) is represented in the sample interval 390A-11-5, 50 $\mathrm{cm}$ to $390 \mathrm{~A}-11-5,145 \mathrm{~cm}$.

\section{Upper Cretaceous}

The Tertiary-Cretaceous boundary occurs in nannofossil ooze which is marked by a subtle but distinct change in color from light gray above to light bluish or greenish gray below (approximate boundary between lithologic units 4-5). The contact is also marked by a distinct change in preservation; the Upper Cretaceous calcareous nannofossils from lithologic unit 5a are excellently preserved, but the lower Danian flora is only moderately well preserved. The lower Danian flora is characterized by the dominance of Braarudosphaera and Thoracosphaera. Upper Cretaceous is represented by upper Campanian-Maestrichtian sediments between 390A-11-5, $149 \mathrm{~cm}$ and 390A-14-5, $80 \mathrm{~cm}$.

Samples from Cores 390-2 and 390A-11-6 to 390A-13-1 contain diverse, well-preserved nannofossils assigned to the upper Maestrichtian Micula mura Zone. Samples from $390 \mathrm{~A}-13-2,125 \mathrm{~cm}$ to $390 \mathrm{~A}-14-5,14 \mathrm{~cm}$ contain moderately well preserved nannofossils assigned to the lower Maestrichtian Arkhangelskiella cymbiformis Zone. An intermediate zone, the middle Maestrichtian Lithraphidites quadratus zone (Martini, 1976) is not present on the basis of its definition: first occurrence of Lithraphidites quadratus to the first occurrence of Micula mura. These two index markers appear together in Sample 390A-13-2, $78 \mathrm{~cm}$ and a middle Maestrichtian hiatus possibly exists between lithologic sub-units $5 \mathrm{a}$ and $5 \mathrm{~b}$.

The upper Campanian Tetralithus trifidus Zone is recognized in Sample 390A-14-5, $72 \mathrm{~cm}$. The presence of $T$. trifidus, T. gothicus, and Lucianorhabdus cayeuxi distinguishes this zone from the overlying Arkhangelskiella cymbiformis. Upper Campanian sediment is represented only by nannofossil ooze between 50 and $80 \mathrm{~cm}$ in Section 390A-14-5.

\section{Lower Cretaceous}

A hiatus of considerable duration is recorded at Sample $390 \mathrm{~A}-14-5,80 \mathrm{~cm}$. The unconformity is bounded by upper Campanian and lower Albian nannofossil oozes. Abundant and moderately well preserved nannofossils of the Parhabdolithus angustus Zone are found in Samples 390A-14-5, $86 \mathrm{~cm}$ and 390A-14, CC and in Samples 390-3, CC; 390-4, CC; and 390-5-2, $102 \mathrm{~cm}$. The Parhabdolithus angustus Zone is present in the type strata bordering the Aptian-Albian boundary.

In Cores 390-5 and 390-6 abundant, but somewhat poorly preserved, nannofossils are assigned to the upper Barremian Micrantholithus hoschulzi Zone. This seems to correspond to a lithologic break in the core-catcher sample of Core 5, in which a white marl is present (lithologic unit 8). Increased numbers of nannoconids and pentaliths (Nannoconus colomii, Micrantholithus hoschulzi, and $M$. obtusus) suggest this unit was possibly deposited in shallower water than were the overlying sediments. Samples in the limestone of Cores 390A-8 and 9 did not contain nannofossils.

\section{RADIOLARIANS}

We found no radiolarian remains in any of the nine cores recovered from Hole 390. In Hole 390A, however, we recovered a continuously cored lower Tertiary and Upper Cretaceous section that contains abundant and well-preserved lower and middle Eocene radiolarians. 
Figure 21 shows the relative abundances and ranges of the most common radiolarians from Hole $390 \mathrm{~A}$. The biostratigraphic zonation employed is from Riedel and Sanfilippo (in press). (See also introduction to this volume.)

The Thyrsocyrtis triacantha Zone is represented at Hole $390 \mathrm{~A}$ in Core 2, Section 1 through Core 4, Section 5 (Figure 22). The base of this zone is recognized by the first morphotypic appearance of Eusyringium lagena. Species frequently occurring within this interval include $T$. mongolfieri, C. ampulla, L. ocellus group, $P$. striata striata, $P$. papalis, $P$. sinuosa, $T$. triacantha, $L$. biaurita, $L$. anoectum, $T$. rhizodon, $T$. amphora group, Lych. bellum, $T$. urceolus, and $C$. hispida.

The Theocampe mongolfieri and Theocotyle cryptocephala cryptocephala zones are not recognized at Hole 390A.

Core 4, Section 6 and Core 5, Section 1 contain no siliceous microfossils.

The Phormocyrtis striata striata Zone occurs in Core 5, Section 2 through Core 6, Section 5. The base of this zone is recognized by the first morphotypic occurrence of Theocorys anaclasta.

Core 6 , Section 6 through Core 7 , Section 4 is assigned to the Buryella clinata Zone (Figure 22). The base of this zone is identified by the evolutionary bottom of Buryella clinata (Figure 21).

The core-catcher sample of Core 7 falls within the Bekoma bidartensis Zone of Riedel and Sanfilippo (in press). This zonal assignment is made on the basis of dominance of $B$. tetradica relative to $B$. clinata.

\section{Depositional Environment}

The Barremian microfossil assemblage and the carbonate lithology of the Barremian strata in Core 390-6 seem to indicate its deposition in shallow water, probably a shelf environment of 50 meters or less (Figure 23). Indeed this fauna is somewhat similar to shallow-water Barremian foraminifer assemblages from the Scotian Shelf, although the latter are in a clastic facies.

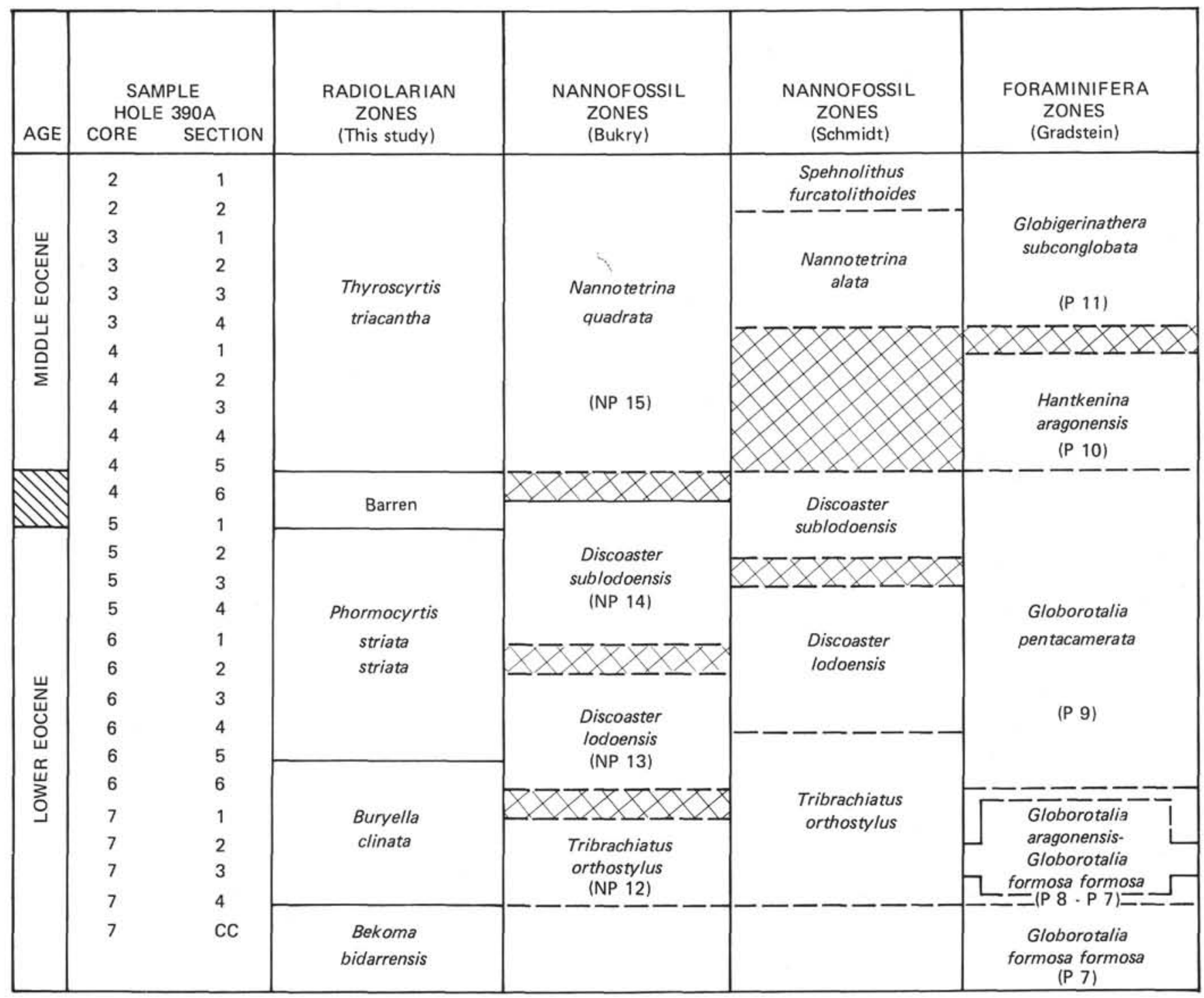

Figure 21. Distribution of radiolarians, Hole $390 \mathrm{~A}$. 


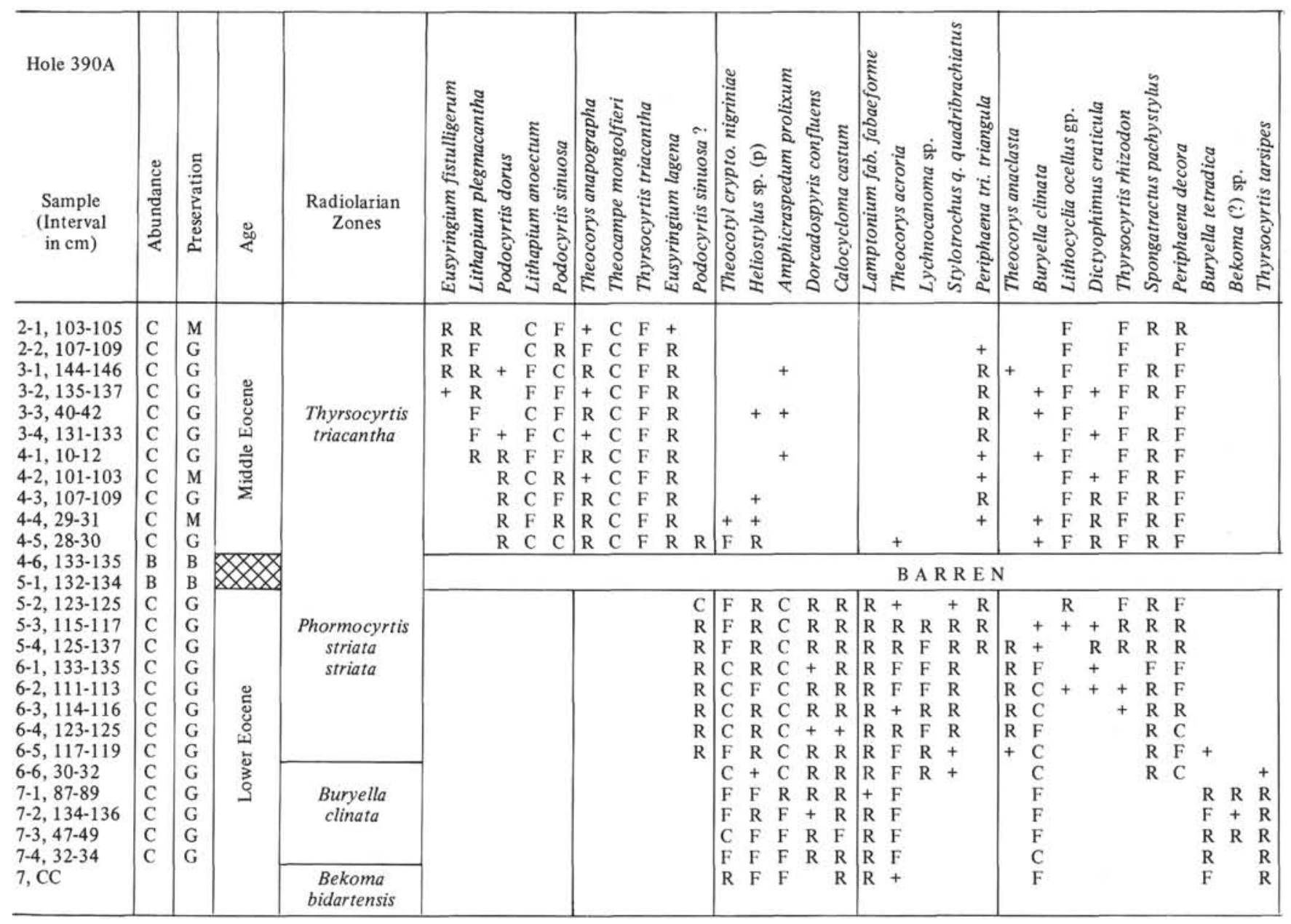

Figure 22. Correlation of planktonic microfossil zones in radiolarian-bearing sediments, Hole $390 \mathrm{~A}$. 


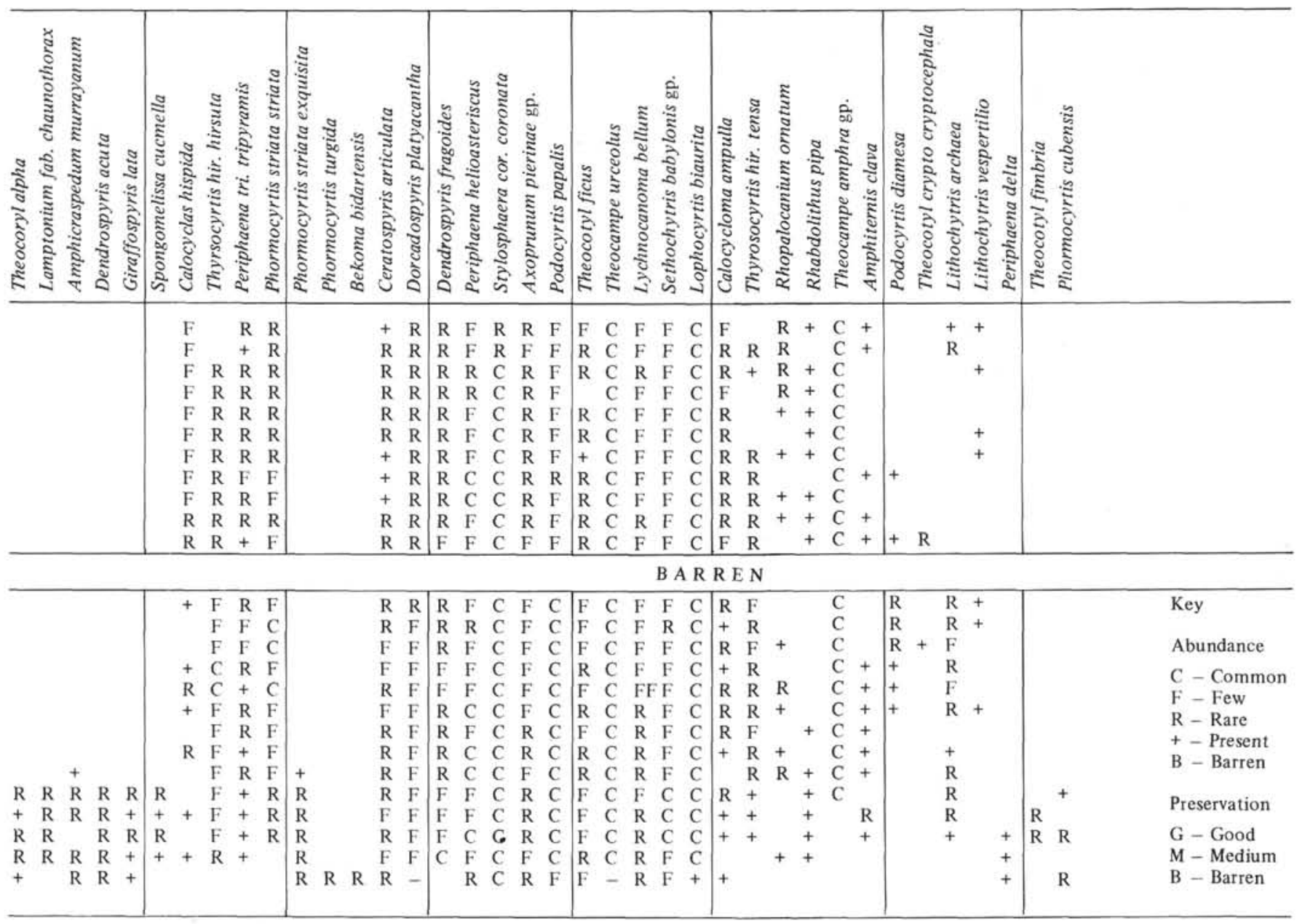

Figure 22. Continued. 
Post-Barremian through middle Eocene sediments are clayey to nearly pure nannofossil oozes whose foraminifer assemblages indicate much deeper water (Figure 23). The high plankton to benthos ratio $(\mathrm{P} / \mathrm{P}+\mathrm{B}$ is around 0.90$)$ in Aptian-Albian sediments with a negligible number of benthic foraminifers is indicative of a minimum water depth of 500 meters. A very shallow marine microfossil assemblage (few individuals) in the upper Aptian ooze may have been introduced by slumping from a nearby shoal into deeper water. Lower Tertiary deposits have a $\mathrm{P} / \mathrm{P}+\mathrm{B}$ ratio equal to about 1 . By Eocene time the site may have been close to its present depth of about $2.6 \mathrm{~km}$ - still well above the CCD. Until a detailed study of Paleocene benthic foraminifers is completed, however, we cannot be certain of the timing.

The relatively high percentage of radiolarians in the middle and lower Eocene sediments is typical in the North Atlantic; it probably reflects a major change in circulation patterns with introduction of Arctic Bottom Water into the North Atlantic. As Site 390 is on the edge of the Blake Escarpment, upwelling may also have played a role in the large numbers of radiolarians.

Note also that the Tertiary nannofossil Braarudosphaera and other pentaliths, forms which are normally interpreted as indicative of shallow-water conditions, are well represented at Site 390. Improved circulation and upwelling could be a cause for their abundance.

Both the Cretaceous and lower Tertiary microfauna and microflora are low latitude, although not fully tropical, types.

\section{SUBSIDENCE AND SEDIMENT ACCUMULATION RATES}

Rates of subsidence and accumulation have been calculated for Site 390 over a period of time covering Barremian through middle Eocene (Figure 24).

The calculations are made on the basis of the following premises:

1) At least half of the Barremian, and all of the Aptian through middle Albian are present in or between Cores 390-6 to $390-3$ and $390 \mathrm{~A}-14-5$, respectively. Poor recovery and lack of biostratigraphic control below Core 6 prevent determination of separate sedimentation rates for the (? lower Aptian) Barremian and/or older limestone of lithologic unit 8 (Cores 5?, CC, 6-9) and for the Aptian through middle Albian variegated nannofossil ooze of unit 7 (Cores 3-5).

2) Approximately half of the Maestrichtian is missing.

3) Sediment accumulation was continuous from early Paleocene through middle Eocene. A best fit of the early Tertiary nannofossil and foraminifer zones (not shown) suggests early Tertiary sediment accumulation was uninterrupted at Site 390. Biozones not detected are in the intervals not cored.

On the basis of these assumptions the following approximate thicknesses have been determined:

Upper Barremian through middle Albian

Upper Campanian through Maestrichtian

$30 \mathrm{~m}$

Lower Paleocene

$29 \mathrm{~m}$

Upper Paleocene

$22 \mathrm{~m}$

$12 \mathrm{~m}$

Lower Eocene

$33 \mathrm{~m}$

Middle Eocene (p.p.)

$42 \mathrm{~m}$

On the basis of these thicknesses, we calculate the average sedimentation rate for the late Barremian through middle
Albian is $0.2 \mathrm{~cm} / 1000 \mathrm{yr}$. Subsidence probably far exceeded this value to account for the change during ?early Aptian time from shallow-water limestone to nannofossil ooze. An estimate of the Barremian water depth is 50 meters, and an estimate of the Aptian-Albian water depth is about 500 meters. If the region subsided 450 meters during the early Aptian, the subsidence rate is rather high: $7 \mathrm{~cm} / 1000 \mathrm{yr}$. If we then assume that the site reached present depth only by the end of the Pliocene, average subsidence rate is slightly over 2 $\mathrm{cm} / 1000 \mathrm{yr}$. (This figure includes about 170 meters of sediment accumulation but erosion and compaction are not taken into account.)

The average sediment accumulation rate for the nannofossil oozes during the late Campanian through part of late Maestrichtian time (lithologic units 6, 5a, and 5b) is approximately $0.7 \mathrm{~cm} / 1000 \mathrm{yr}$. The rate may be higher if more than half of the Maestrichtian time is represented as a hiatus in 390A-13.

Early Paleocene, late Paleocene, and early Eocene rates are respectively $0.5,0.2$ and $0.8 \mathrm{~cm} / 1000 \mathrm{yr}$. The average is about 0.4 which rises to about $1.5 \mathrm{~cm} / 1000 \mathrm{yr}$ in middle Eocene time, although the lithology remains an ooze. Much higher biogenic production may have caused this sudden increase. This accords with an improved middle Eocene circulation postulated in the discussion above (Depositional Environment).

\section{CORRELATION OF SEISMIC REFLECTION PROFILE WITH DRILLING RESULTS}

The reasonably good seismic reflection profile recorded during the site survey (Figure 8) shows a pronounced angular unconformity just west of the site above which the sediments are highly stratified. But although they are well stratified, the seven sedimentary units identified in the cores are comparatively thin (Figure 25). Some of the lithologic intervals are thinner than the fundamental wavelength of the bubble pulse from the airgun which caused interference on the record. Thus some of the correlations are less than certain. The more prominent reflectors were traced, albeit with some difficulty, through the interference and at least five reflectors are present at the site (Figure 25), at 0.09, $0.12,0.19,0.21$, and $0.38 \mathrm{sec}$ sub-bottom depth. The reflector at $0.19 \mathrm{sec}$ sub-bottom is clearly a major angular unconformity, below which at least three reflectors, present to the west, have been successively truncated eastward and do not reach Site 390. The reflectors above the 0.19 unconformity are apparently of regional extent and can be traced west onto the main part of the Blake Plateau (see also Background and Objectives). The reflector at $0.09 \mathrm{sec}$ sub-bottom is correlated with reflector 1 of Ewing et al. (1966) and the reflector at $0.19 \mathrm{sec}$ is reflector 4 . The deeper reflectors seen in these Glomar Challenger profiles also extend under the Blake Plateau; they continue at depths of 2.6-3.0 sec and are observable only on multichannel CDP data (Dillon et al., 1976).

We correlate the shallowest reflector, at $0.09 \mathrm{sec}$ sub-bottom, with tan cherty limestones that are interbedded with the lower Eocene and upper Paleocene nannofossil oozes. These thin units are recrystallized and are very hard compared to the enclosing soft oozes. This shallow reflector is very strong and is clearly planar under the erosional hills and notches in the overlying sediments. The velocity 


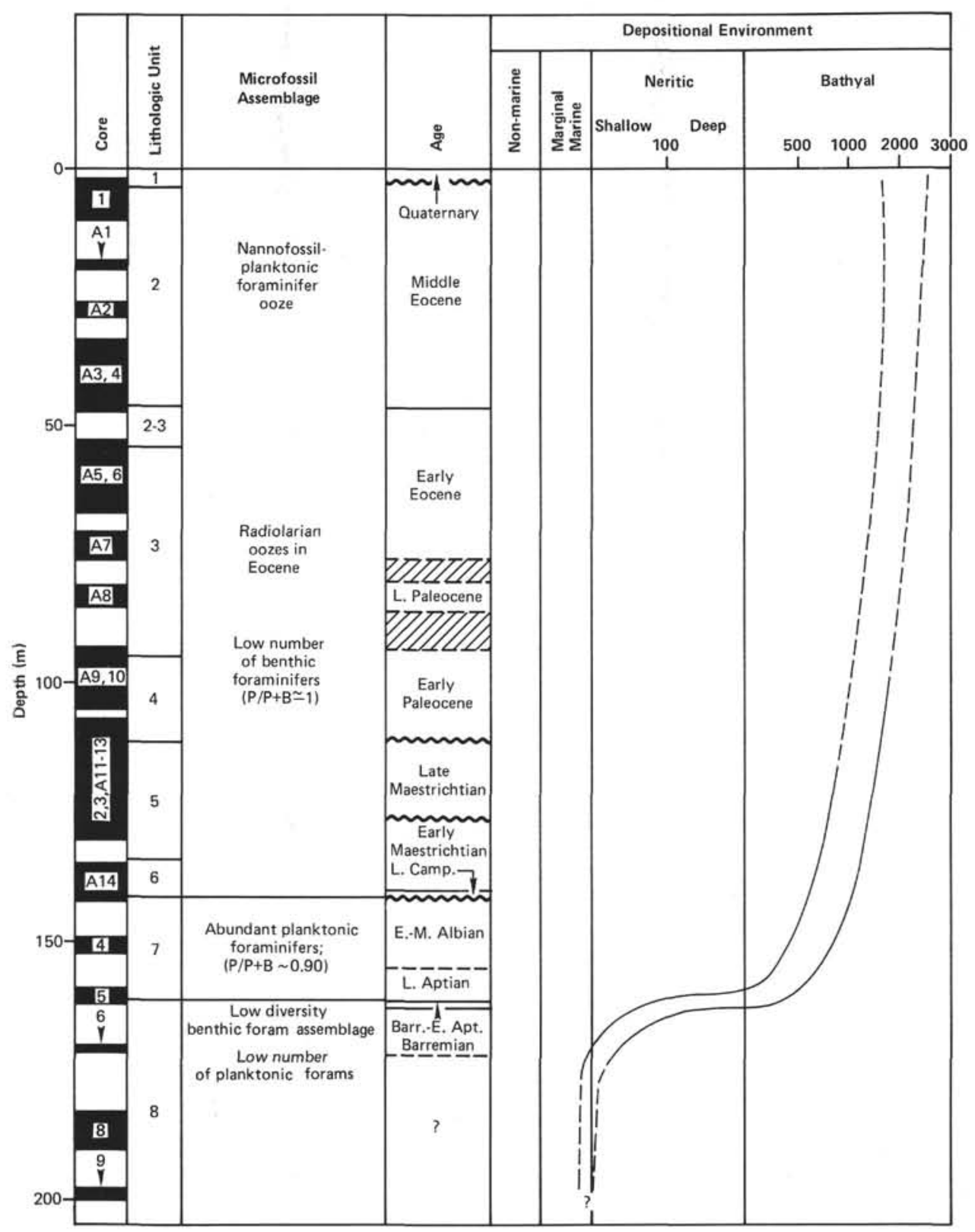

Figure 23. Stratigraphy and depositional environment, Holes 390 and 390A, Blake Nose.

calculated for the Eocene oozes (sub-bottom depth in seconds divided into the drilled depth) is $1.62 \mathrm{~km} / \mathrm{sec}$, which is consistent with the shipboard measured velocities of 1.49-1.59 km/sec.

The next deeper reflector, at $0.12 \mathrm{sec}$ sub-bottom, is weak. It probably correlates with a small lithologic change within the lower Paleocene (Danian) beds, where some slightly stiffer clays show a measured velocity of 1.61 to 1.67 $\mathrm{km} / \mathrm{sec}$. But if this correlation is correct, the calculated interval velocity for the ooze above this reflector is only 1.4 $\mathrm{km} / \mathrm{sec}$, significantly lower than the 1.58 to $1.67 \mathrm{~km} / \mathrm{sec}$ velocity measured on the cores. The discrepancy could result from poor resolution of the exact sub-bottom depth of this reflector.
As noted above, a very strong reflector at $0.19 \mathrm{sec}$ marks an important angular unconformity. At Site 390 the unconformity is marked by the lithologic change from the softer Maestrichtian/Campanian oozes (measured velocities of 1.59 to $1.65 \mathrm{~km} / \mathrm{sec}$ ) to firm beds of variegated Albian-Aptian sediments (measured velocities of 1.71 to $1.72 \mathrm{~km} / \mathrm{sec}$ ). On the basis of this correlation the calculated interval velocity is only $1.5 \mathrm{~km} / \mathrm{sec}$ for the units above this reflector, again suggesting some error. In this case, however, the correlation of the reflector with the unconformity shown in the cores is strong.

The deepest reflector cored at Site 390 is at $0.21 \mathrm{sec}$ sub-bottom. It is tentatively correlated with the boundary between the Aptian-Albian nannofossil ooze and the white 


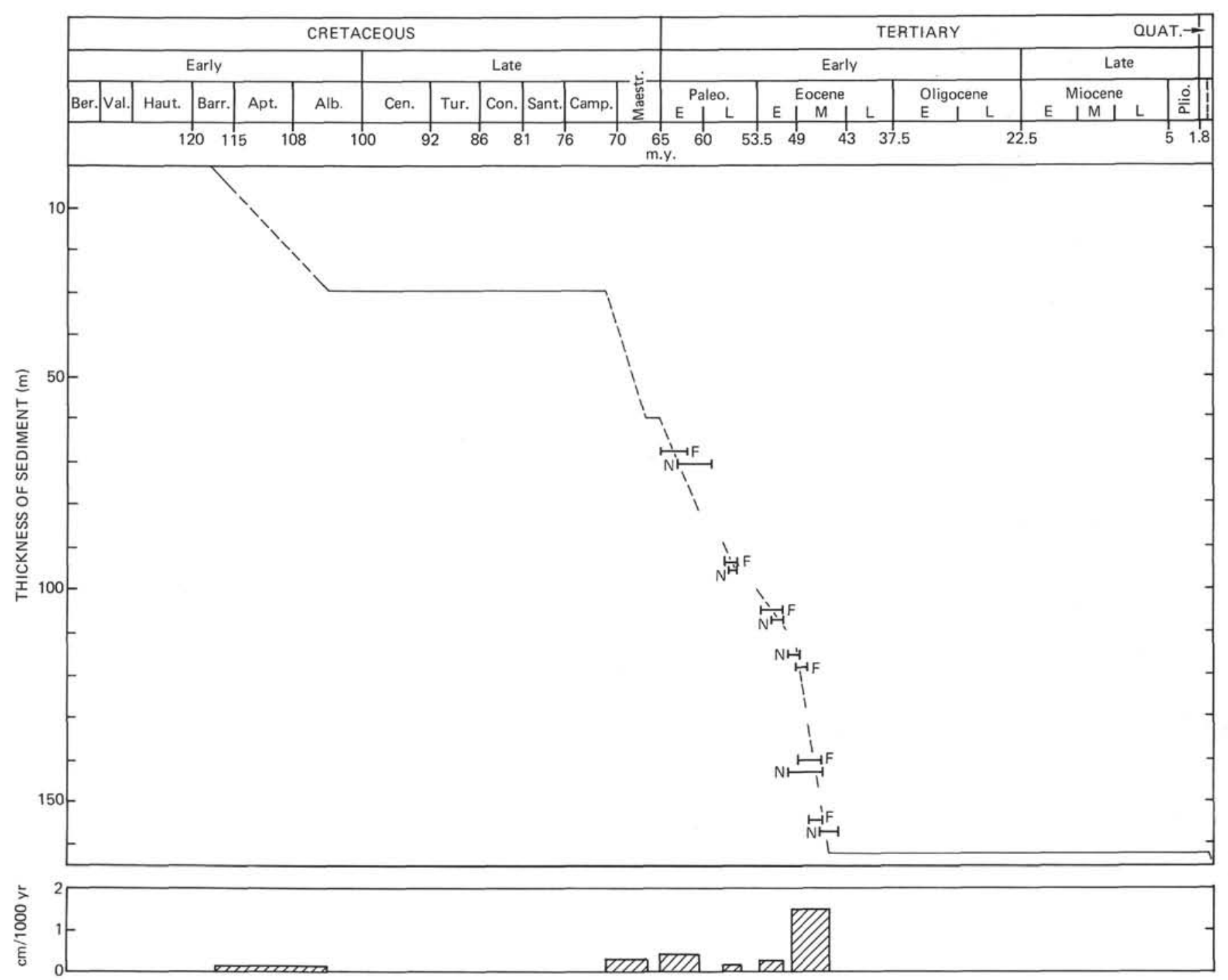

Figure 24. Rate of sediment accumulation since Barremian time at Site 390, Blake Nose.

crumbly Barremian or older limestone. An interval velocity of $1.60 \mathrm{~km} / \mathrm{sec}$ is calculated for the Aptian-Albian above this reflector.

A deeper reflector at $0.38 \mathrm{sec}$ sub-bottom was not reached by the drilling at Site 390 .

\section{SUMMARY AND CONCLUSIONS}

The Blake Nose is a northeast-jutting spur of the Blake Plateau east of Florida. Previous reflection profiles and dredgings indicate that an extension of a mid-Cretaceous reef-bank complex that rings the Gulf of Mexico and extends through Cuba and the Bahamas (see Background and Objectives, above) may crop out on the lip of the Blake Nose.

We drilled Sites 389 and 390 in the Blake Nose to learn more about the reef-bank complex. The two sites were drilled only 1200 meters apart and are therefore summarized together.

The specific objectives of the site were (1) to sample the sedimentary section above the reef-bank or rim complex; (2) identify several prominent reflecting horizons; (3) drill into the reef-bank rim complex, either an organic reef itself or some off-reef facies of the carbonate bank; and (4) to determine, if possible, the time and a cause of the cessation of reef-bank buildup. Results of drilling at Site 390 are graphically summarized in Figure 26.

\section{Site Survey}

The Cretaceous reefs and associated deposits are known to contain petroleum in Mexico and southern U.S. To avoid accidentally drilling into a reservoir our site location was limited to an area near the edge of the escarpment where earlier surveys had shown that no potential structural traps are present and where any hydrocarbons that might have been present would have been removed by salt-water flushing. Selection of our site location was further constrained by detection of an angular unconformity to the west with truncation of some westward dipping strata during our survey of the area with Glomar Challenger. Sites 389 and 390 were consequently located on the northeast end of the Blake Nose, east of the apparent pinch-outs and over flat-lying or slightly synclinal beds. (Figures 8 and 27). This also took us away from the prominent rough opaque reflector on the south side 


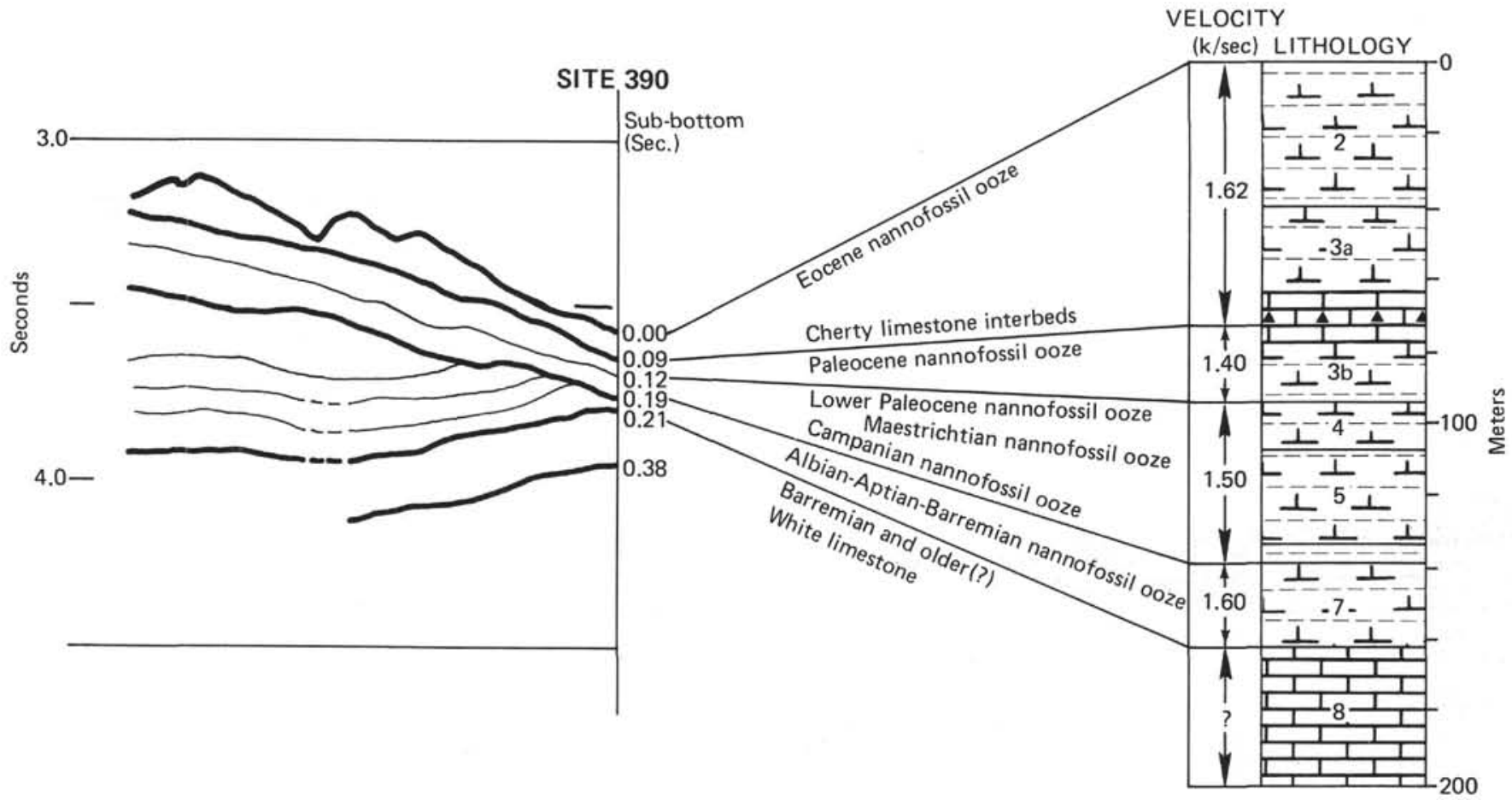

Figure 25. Correlation of seismic profile with lithology, Site 390. Velocities are calculated based on correlation and drilling depths.

of the nose which is thought to be a massive organic reef-complex. The various reflectors identified in the survey and their interpretation are discussed below.

\section{Stratigraphy}

The sediments cored at Sites 389 and 390 were divided into eight units. The uppermost unit is a lag concentrate of sand and gravel consisting of manganese nodules, foraminifer tests, and fragments of several types of macrofossils. The layer forms a patchy veneer on this part of the Blake Plateau and its Quaternary age indicates that strong currents have flowed across the Blake Nose since at least early Pleistocene time.

The seven underlying units comprise only 206 meters but span an interval from middle Eocene to at least Early Cretaceous (Barremian). The upper six units are nannofossil oozes that are differentiated largely by color, degree of induration, and clay content. All were deposited under pelagic conditions (i.e., in water at least $500 \mathrm{~m}$ deep), and all have warm water, although not tropical, floras and faunas. Unit 3 (lower Eocene and upper Paleocene) contains beds that have been lithified to a tan limestone; some of these beds have been partly replaced by chert. Of special importance is the occurrence of radiolarians, foraminifers, and nannofossils throughout the Eocene beds which allow a rare opportunity for biostratigraphic comparisons.

The lowest unit is a 48-meter thick white limestone with a Barremian fauna in the upper part and lacking datable fossils below. Part of the limestone is oolitic; much of it is chalky and suggestive of shallow-water carbonate muds. Much of the limestone has leached porosity that may have been formed subaerially. The fauna in the upper part is, except for one ammonite and a few globigerinids, of shallow benthic organisms. All the physical and paleontologic evidence, therefore, indicates that this limestone was deposited in shallow water, certainly less than 1000 meters and quite possibly less than 50 meters deep.

Possible hiatuses in the section were noted at the Paleocene/Eocene boundary and within the Paleocene. A definite gap occurs across the Cretaceous/Paleocene boundary where part of the upper Maestrichtian appears to be missing. The largest time gap is between lithologic units 6 and 7 where Campanian overlies Albian sediments (Figure 26). This unconformity can be traced westward on the seismic profile (Figures 8 and 27) where it becomes angular and truncates Upper Cretaceous beds that are missing at Site 390.

Sediment accumulation rates are: $1 \mathrm{~mm} / 10^{3} \mathrm{yr}$ for the Albian-Aptian oozes, $2-4 \mathrm{~mm} / 10^{3} \mathrm{yr}$ for the Campanian through lower Eocene oozes, and a surprising $15 \mathrm{~mm} / 10^{3} \mathrm{yr}$ for the middle Eocene ooze. This last must record a time of unusually high productivity during the middle Eocene.

Subsidence rates are uncertain at best. If the Barremian limestone was deposited in 50-100 meters of water and the Aptian-Albian in at least 500 meters, the platform subsided at a minimum rate of $7 \mathrm{~cm} / 10^{3} \mathrm{yr}$. This rate, while relatively high, is not unusual for the Lower Cretaceous of the Blake-Bahama area where more than 2500 meters of sediments have accumulated in about 25 million years (Heezen and Sheridan, 1966). Post-Aptian rates are more uncertain and depend on when subsidence is presumed to have ceased. 


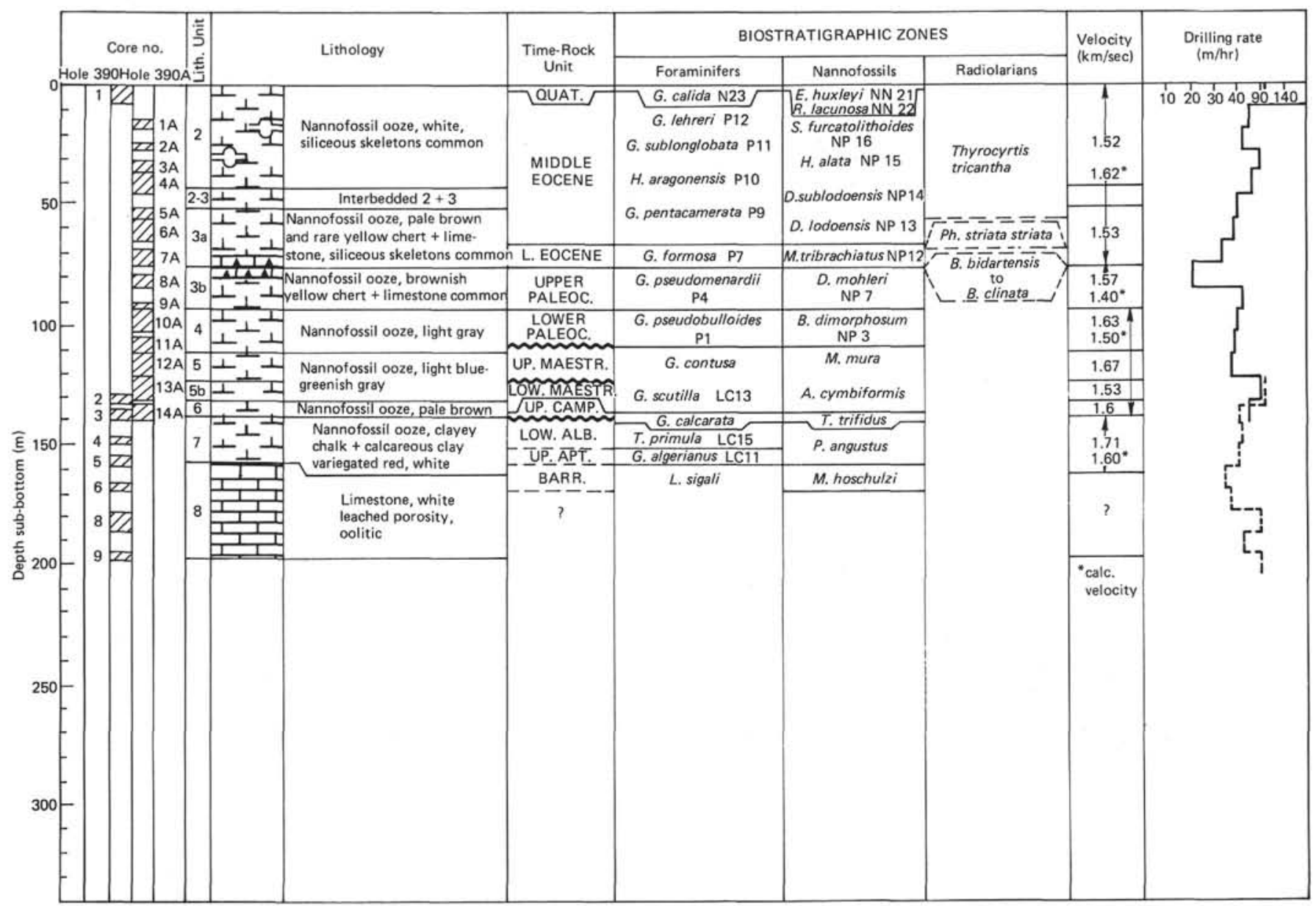

Figure 26. Graphic summary of Site 390.

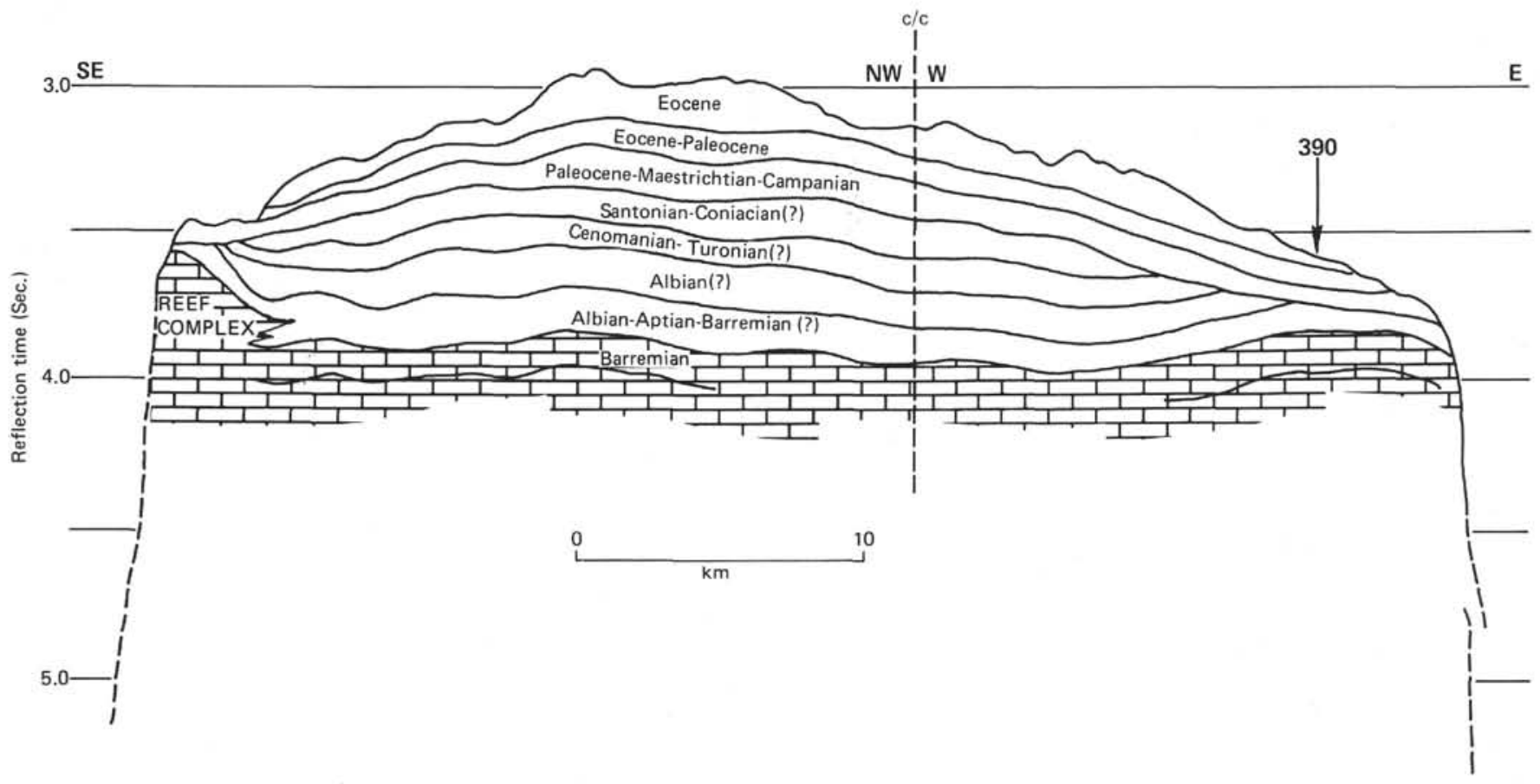

Figure 27. Geologic cross-section across Blake Nose interpreted on basis of Site 390 drilling. 


\section{Correlation of Reflectors}

Five sub-bottom reflectors were noted during the site survey. Four of them were penetrated at Site 390 and can be correlated with the cored section. A strong reflector at 0.09 sec sub-bottom correlates with the top of an interval of lithified limestones and chertified beds in the lower Eocene-upper Paleocene ooze (unit $3 \mathrm{a} / 3 \mathrm{~b}$ ). This reflector correlates with the reflector 1 of Ewing et al. (1966), extensively mapped on the Blake Plateau. The reflector at $0.12 \mathrm{sec}$ is weak and probably correlates with a general downward increase in the stiffness of the lower Paleocene (Danian) beds. The very strong reflector at $0.19 \mathrm{sec}$ marks the major unconformity between the Aptian/Albian and the Campanian beds, and the moderate reflector at $0.21 \mathrm{sec}$ represents the top of the Barremian limestone. All these reflectors, and especially the upper two, are traceable westward onto the Blake Plateau, which aids correlation and interpretation of other reflection profiles. The $0.19 \mathrm{sec}$ reflector correlates with reflector 4 of Ewing et al. (1966) and the $0.21-\mathrm{sec}$ reflector correlates with a reflector at 2.6 to 3.0 sec under the Plateau (Dillon et al., 1976).

\section{Cretaceous Reef Building on Blake Nose}

On the basis of correlation of the seismic reflection profile (Figure 8) with the results of the drilling, we may construct a 40-50 km geologic cross-section across the Blake Nose (Figure 27). The ages of the seismic layers are well documented in Holes 390 and 390A. The hiatus between Albian and Campanian sediments at Site 390 is seen on the seismic profile to rise to the west, suggesting that Santonian through Cenomanian strata are also present on the Blake Nose. Projection of the observed Campanian-Eocene sediment accumulation rates would give the proper sediment thickness for these proposed Santonian-Campanian layers. By extrapolating these correlations and assuming that the reflectors remain reasonably isochronous over the nose, we infer a possible Barremian age for the reef-bank complex on the southeast lip (Figure 27). Here, as in other seismic reflection profiles across the edge of the Blake Escarpment, a rough reflector, opaque to sonic transmission and with associated hyperbolic side echoes, is probably caused by the rough irregular surface on a massive lithified limestone reef-complex (Ewing et al., 1966; Sheridan et al., 1971). Well-lithified Upper Cretaceous limestones of lagoonal or shelf facies have been recovered by dredging just below this lip and along other parts of the escarpment (Sheridan et al., 1971). Dredging fro below 2300 meters has recovered Neocomian to Albian shelf and bank sediments (Heezen and Sheridan, 1966). Although these dredges were quite far from the reef-bank complex shown on Figure 27, the seismic data indicate that the feature is persistent, and extrapolation to the Challenger profile seems reasonable.

The lithologic data from Site 390 record a shallow-water environment in the Barremian followed by continuous deep-water conditions. Even the hiatus between Albian and Campanian apparently was formed in a deep-water environment, presumably by strong bottom currents. This angular unconformity, although impressive in the amount of erosion that occurred, shows no evidence of shallow-water or subaerial conditions.

Strong bottom currents are known to exist today along the Blake Escarpment (Heezen et al., 1966), and the presence at
Site 390 of mid-Eocene ooze capped by the veneer of Quaternary gravel tells of strong currents during Tertiary and Quaternary time. Strong currents apparently also prevailed during some part of the Late Cretaceous. If they were predominantly post-Santonian to pre-late Campanian, they could account for the inferred angular unconformity near Site 390 as shown in Figure 25. Moreover, extrapolation of the inferred sediment accumulation rates for the Blake Nose favors the presence of some Santonian-Cenomanian sediments which would have been deposited before the currents eroded these beds under the angular unconformity. In addition, if the currents began earlier, e.g., in Cenomanian time, they would have been active at the same time the black shale was deposited (presumably under stagnant conditions) in the deep basins of the North Atlantic (Hollister et al., 1972). This would require either unusually strong shear boundaries within the water mass or that the black shales be deposited under conditions other than simple stagnation. Following the principle of maximum simplicity, we suggest that the evidence favors a post-Santonian time for the strong current.

When traced southeast from Site 390 to where the reef is inferred from seismic data to be (Figure 27), the Cretaceous ooze evidently changes facies. Seismic reflectors of almost certain Albian-Aptian sediments rise onto the massive reef structure with apparent off-reef draping. We thus infer that the reef-bank complex on the southeast lip of the Blake Nose continued to grow upward, while the Barremian carbonate bank complex to the north was subsiding and receiving increasingly pelagic sediments during Aptian-Albian time. This interpretation is further supported by the occurrence of a few very shallow-water foraminifers among the predominantly pelagic forms in the Aptian-Albian ooze of Hole 390. The relief in the reflectors plus their apparent roughness near the edge of the Nose suggests that reef development persisted even into at least Barremian time.

After the Barremian, however, there seems to be no identifiable reef-complex structure that correlates with the Maestrichtian-Campanian oozes. Thus reef building must have ceased by at least Campanian time. If indeed the reef-bank buildup persisted further west on the Blake Plateau into Santonian time, its cessation would have coincided with the probable advent of the strong currents discussed above. In this model, any reef bank-complex buildup which kept pace with the post-Barremian subsidence, could probably not endure the new extra stress. The currents caused some ecological imbalance - perhaps a nutrient imbalance, or, more likely, an excessive influx of inert "'mud" — and the conditions responsible for the reef-bank buildup, already strained to the critical point, would have disappeared.

\section{Coda}

The major objectives of drilling on the Blake Nose were achieved. We sampled the lower Tertiary and Upper Cretaceous beds by continuous coring and were able to correlate the reflecting horizons with the lithology. Although we did not drill a Cretaceous organic reef mass itself we cored a shallow-water carbonate bank counterpart and developed a model for the cause and timing of the cessation of the seismically identified reef-bank complex.

New and unexpected information derived from Sites 389 and 390 includes: (1) evidence that the strong bottom currents 
in the area may have started in the Late Cretaceous and have persisted intermittently since; (2) finding a replacement-type chert associated with lithified Paleocene limestone; and (3) finding an Eocene section that contains all three major groups of planktonic microfossils - radiolarians, foraminifers, and nannofossils - providing an unusual opportunity to intercorrelate biostratigraphic zones. This last may well be the most significant accomplishment of drilling at the site.

\section{REFERENCES}

Bartenstein, H., 1976. Practical applicability of a zonation with benthonic foraminifera in the worldwide Lower Cretaceous; Geol. Mijnbouw, v. 55, p. 83-86.

Bartenstein, H. and Bolli, H.M., 1973. Die Foraminiferen der Unterkreide von Trinidad, W.I. - Maridale Formation (cotyplokalitat); Eclog. Geol. Helv., v. 66, p. 389-418.

Bartenstein, H., Bettenstaedt, F., and Bolli, H.M., 1957. Die Foraminiferan der Unterkreide von Trinidad, B.W.I. teil I, Eclog. Geol. Helv., 50, p. 5-65.

, 1966. Die Foraminiferen der Unterkreide von Trinidad, W.I. Maridale Formation (typlokalitat); Eclog. Geol. Helv., v. 59 , p. $129-175$.

Bolli, H.M., 1966. Zonation of Cretaceous to Pliocene marine sediments based on planktonic foraminifera: Bol. Inform. Assoc., Venezuelana Geol. Miner. Petrol., v. 9, p. 3-32.

Boyce, R.E., 1973. Physical properties measurement. In Edgar, N.T., Saunders, J.B., et a., Initial Reports of the Deep Sea Drilling Project, v. 15: Washington (U.S. Government Printing Office), p. 1121-1124.

Bramlette, M.N. and Martini, E. (1964). The great change in calcareous nannoplankton fossils between the Maestrichtian and Danian; Micropaleontology, v. 10, p. 291-322.

Bukry, D., 1973. Low-latitude coccolith biostratigraphic zonation. In Edgar, N.T., Saunders, J.B. et al., Initial Reports of the Deep Sea Drilling Project, v. 15: Washington (U.S. Government Printing Office), p. 685-703.

Calvert, S.E., 1974. Deposition and diagenesis of silica in marine sediments: In Pelagic sediments on land and under the sea: Hsu, K.J., and Jenkyns, H.C., (Eds.), Int. Assoc. Sedimentologists Spec. Pub. 1, p. 273-299.

Cita, M.B. and Gartner, S., Jr., 1971. Deep sea Upper Cretaceous from the western North Atlantic, Second Plankt. Conf. Proc., Rome 1970 , v. 1, p. 287-320.

Dillon, W.P., Fail, J.P., and Cassand, J., 1976. Structure of the continental margin off Georgia, South Carolina, and North Carolina as shown by multichannel CDP profiles (abs.), EOS Trans. Am. Geophys. Union, v. 57, p. 265.

Douglas, R.G., 1974. Benthonic foraminiferal biostratigraphy in the Central North Pacific, Leg 17, Deep Sea Drilling Project. In Winterer, E.L., Ewing, J.I., et al., Initial Reports of the Deep Sea Drilling Project, v. 17: Washington (U.S. Government Printing Office), p. 607-672.

Enos, Paul, 1974. Reefs, platforms, and basins of the Middle Cretaceous of northeastern Mexico, Amer. Assoc. Petroleum Geologists Bull., v. 58, p. 800-809.

Ewing, J.I., Ewing, M., and Leyden, R., 1966. Seismic profiler survey of the Blake Plateau, Am. Assoc. Petrol. Geol. Bull., v. 50 , p. $1948-1971$.

Foreman, H.P., 1973. Radiolaria of Leg 10 DSDP.In Worzel, J.L., et al., Initial Reports of the Deep Sea Drilling Project, v. 10: Washington (U.S. Government Printing Office), p. 407-474.

Gartner, S., 1971. Calcareous nannofossils from the JOIDES Blake Plateau cores, and revision of Paleogene nannofossil zonation, Tulane Stud. Geol. Paleontol., v. 8, p. 101-121.

Gieskes, Joris M., 1974. Interstitial water studies, Leg 25. In Vallier, T.L., White, S.M., et al., Initial Reports of the Deep
Sea Drilling Project, Volume 25: Washington (U.S. Government Printing Office), p. 361-374.

Gieskes, Joris M., and Lawrence, James R., 1976. Interstitial water studies, Leg 35. In Hollister, C.D., Craddock, C., et al., Initial Reports of the Deep Sea Drilling Project, Volume 35: Washington (U.S. Government Printing Office), p. 407-424.

Heezen, B.D., Hollister, C.D., and Ruddeman, W.F., 1966. Shaping of the Continental Rise by deep geostrophic contour currents, Science, v. 152 , p. 502-508.

Heezen, B.C. and Sheridan, R.E., 1966. Lower Cretaceous rocks (Neocomian-Albian) dredged from Blake Escarpment, Science, v. 154 , p. $1644-1647$.

Hollister, C.D., Ewing, J.I., Habib, D., Hathaway, J.C., Lancelot, Y., Luterbacher, H., Paulus, F., Poag, C.W., Wilcoxon, J.A. and Worstell, P., 1972. Initial Reports of the Deep Sea Drilling Project, v. II: Washington (U.S. Government Printing Office).

Krasheninnikov, V.A. and Hoskins, R.H., 1973. Late Cretaceous, Paleogene, and Neogene planktonic foraminifera. In Heezen, B.C., MacGregor, I.D., et al., Initial Reports of the Deep Sea Drilling Project, v. 20: Washington (U.S. Government Printing Office), p. 105-203.

Martini, E., 1971. Standard Tertiary and Quaternary calcareous nannoplankton zonation: Second Plankt. Conf., Proc., Rome 1970 , v. 2 , p. $739-785$.

Meyerhoff, A.A. and Hatten, C.W., 1974. Bahamas salient of North America. In The geology of continental margins, Burk, C.A., Drake, C.L. (Eds.). New York (Springer-Verlag), p. 429-446.

Michael, E., 1966. Die Evolution der Gavelinelliden (Foram.) in der N.W. Deutschen Unterkreide, Senck. Leth., v. 47, p. 411-459.

Milliman, J.D., Pilkey, O.H., and Ross, D.A., 1972. Sediments of the Continental Margin of the eastern United States, Geol. Soc. America Bull., v. 83, p. 1315-1334.

Paulus, F.J., 1972. The geology of Site 98 and the Bahama Platform. In Hollister, C.D., Ewing, J.I., et al., Initial Reports of the Deep Sea Drilling Project, v. II: Washington (U.S. Government Printing Office), p. 877-897.

Riedel, W.R., and Sanfilippo, A., in press.

Sanfilippo, A. and Riedel, W.R., 1973. Cenozoic Radiolaria from the Gulf of Mexico, DSDP, Leg 10. In Worzel, J.L., et al., Initial Reports of the Deep Sea Drilling Project, v. 10. Washington (U.S. Government Printing Office), p. 475-611.

Schlee, J., Behrendt, J.C., Grow, J.A., Robb, J.M., Mattick, R.E., Taylor, P.T., and Lawson, B.J., 1976. Regional Framework off Northeastern United States, Am. Assoc. Petrol. Geol. Bull., v. 60, p. 926-951.

Schlee, J., Mattick, R., Grow, J., and Behrendt, J., 1975. Stratigraphic and structural framework of the Atlantic Continental Margin off the Mid-Atlantic Statesn Open File Reportn U.Sm Geological Survey.

Sheridan, R.E., 1974. Atlantic Continental margin of North America: In The geology of continental margins: Burk, C.A. and Drake, C.L., (Eds.), (Springer-Verlag), p. 391-407.

Sheridan, R.E., Berman, R.M., and Corman, D.B., 1971. Faulted limestone block dredged from Blake Escarpment, Geol. Soc. Am. Bull., v. 82, p. 199-206.

Simon, W. and Bartenstein, H., (Eds.) 1962. Leitfossilien der Mikropalaontologie Gebr. Borntraeger, Berlin.

Stainforth, R.M., Lab, J.L., Luterbacher, H., Beard, J.H., and Jeffords, R.M., 1975. Cenozoic Planktonic Foraminiferal Zonation and Characteristics of Index Forms. The University of Kansas, Paleontol. Contrib. Art. 62, p. 425.

Thierstein, H.R., 1973. Lower Cretaceous Calcareous Nannoplankton Biostratigraphy, Abh. Geol. Bundesanst., Wien, p. 1-52.

van Hinte, J.E., 1976. A Cretaceous time scale, Am. Assoc. Petrol. Geol. Bull., v. 60 , p. $498-516$. 

Hole 389 Core 1

Cored Interval: $30.0-39.5 \mathrm{~m}$

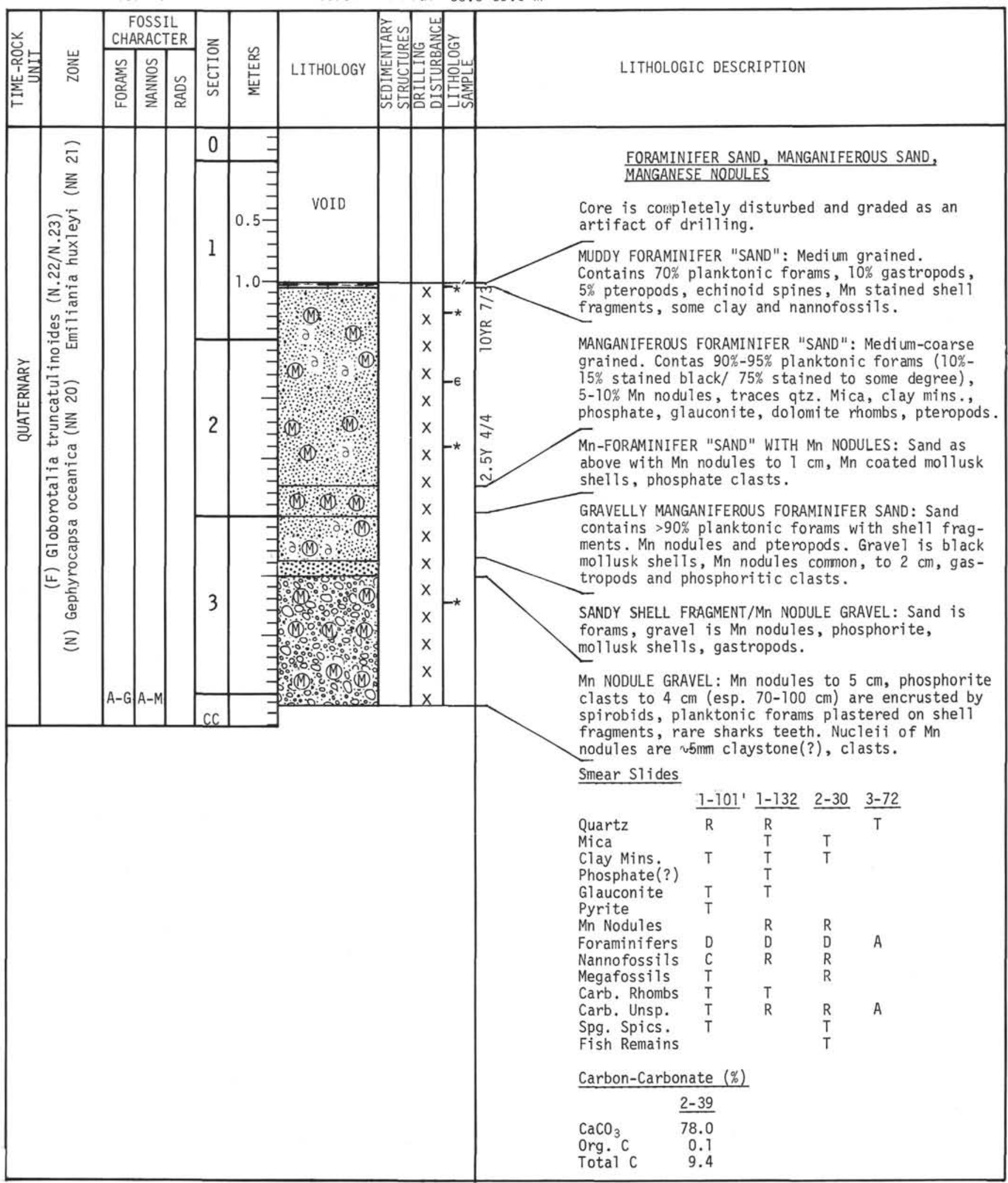


DENSITY $(\mathrm{gm} / \mathrm{cc})$

Site 389

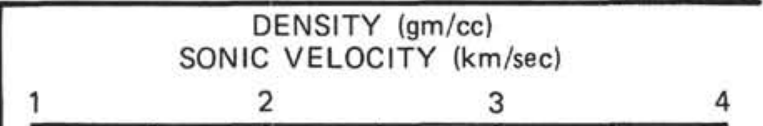

SECTION

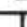

G

G

G
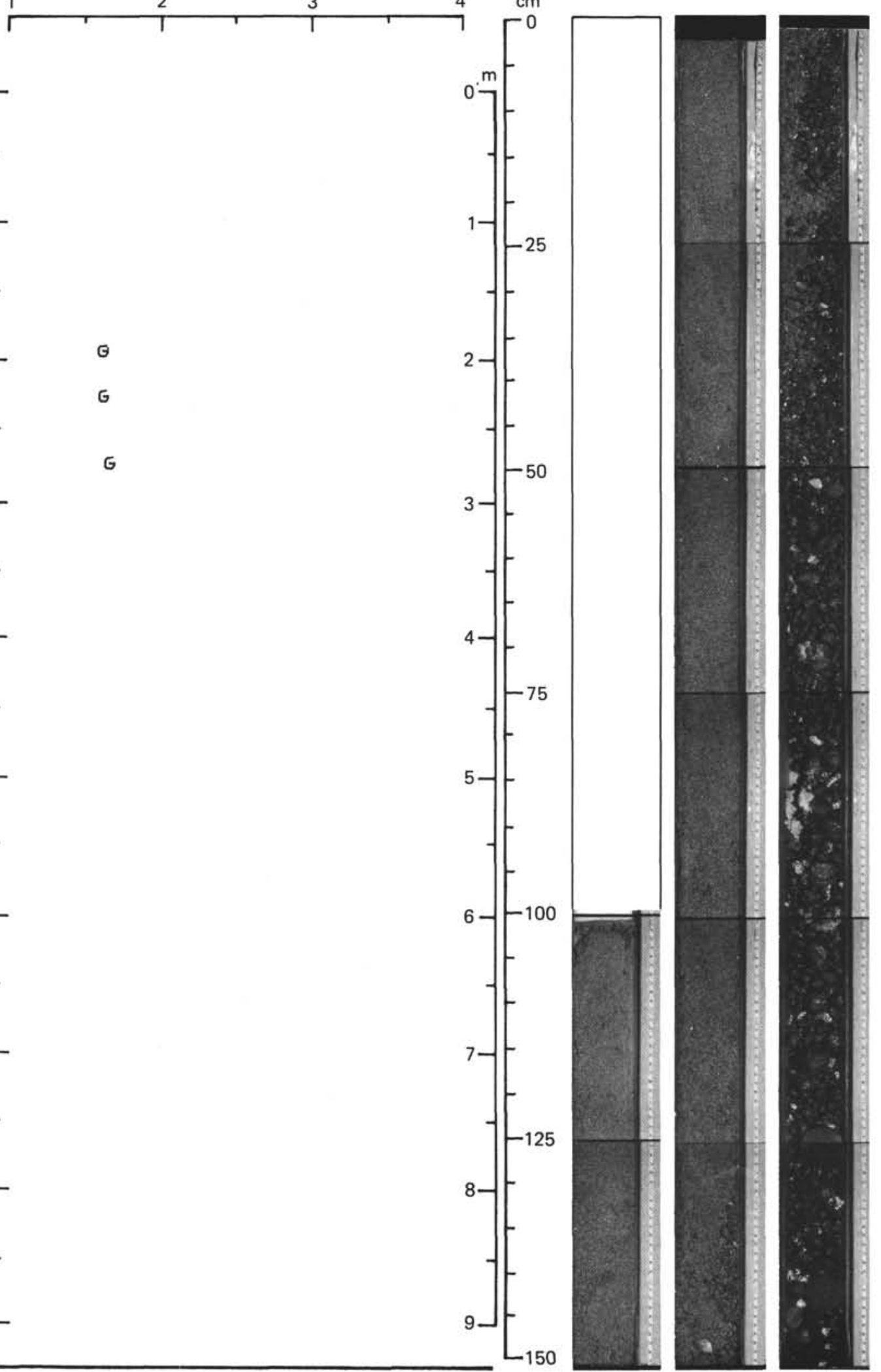


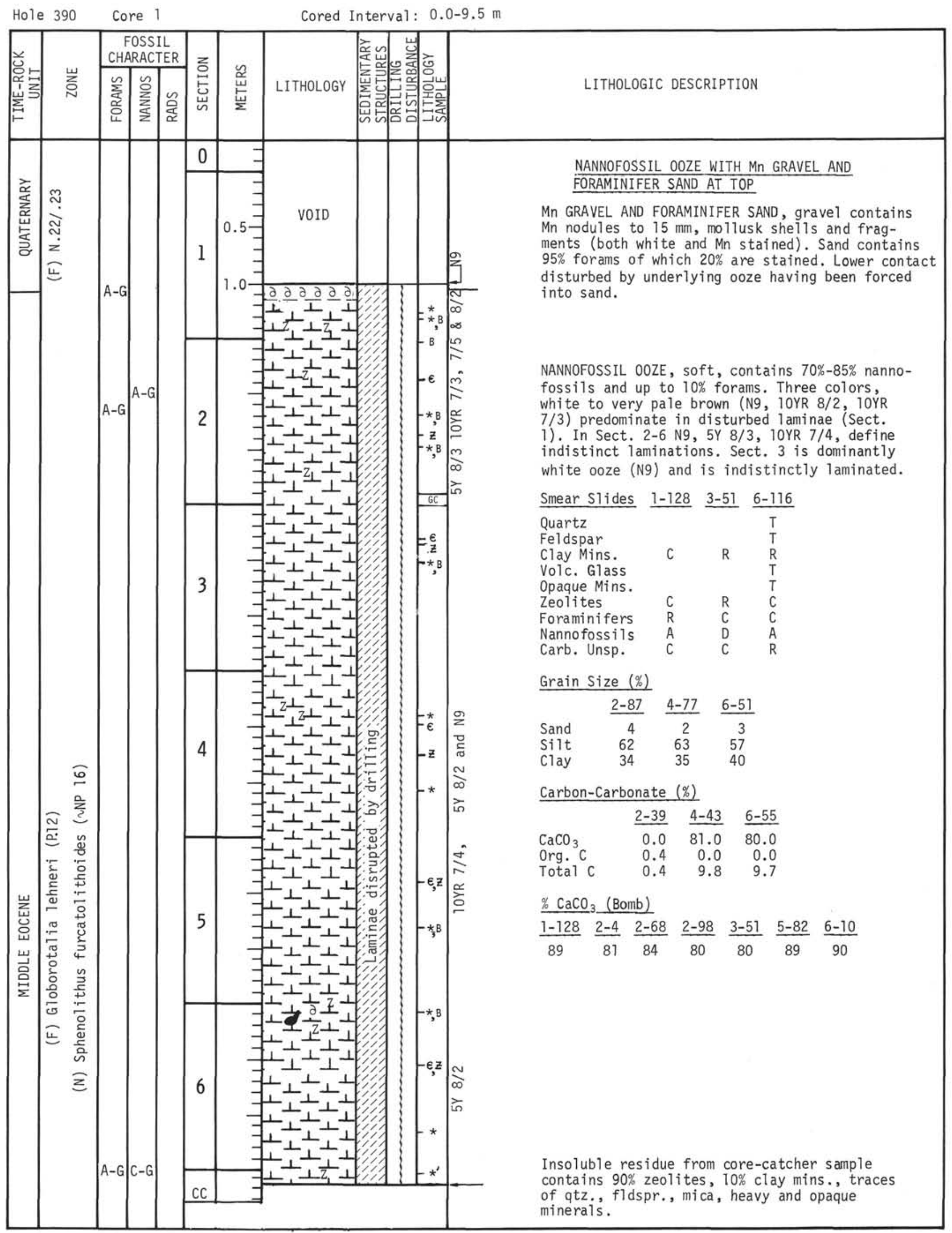




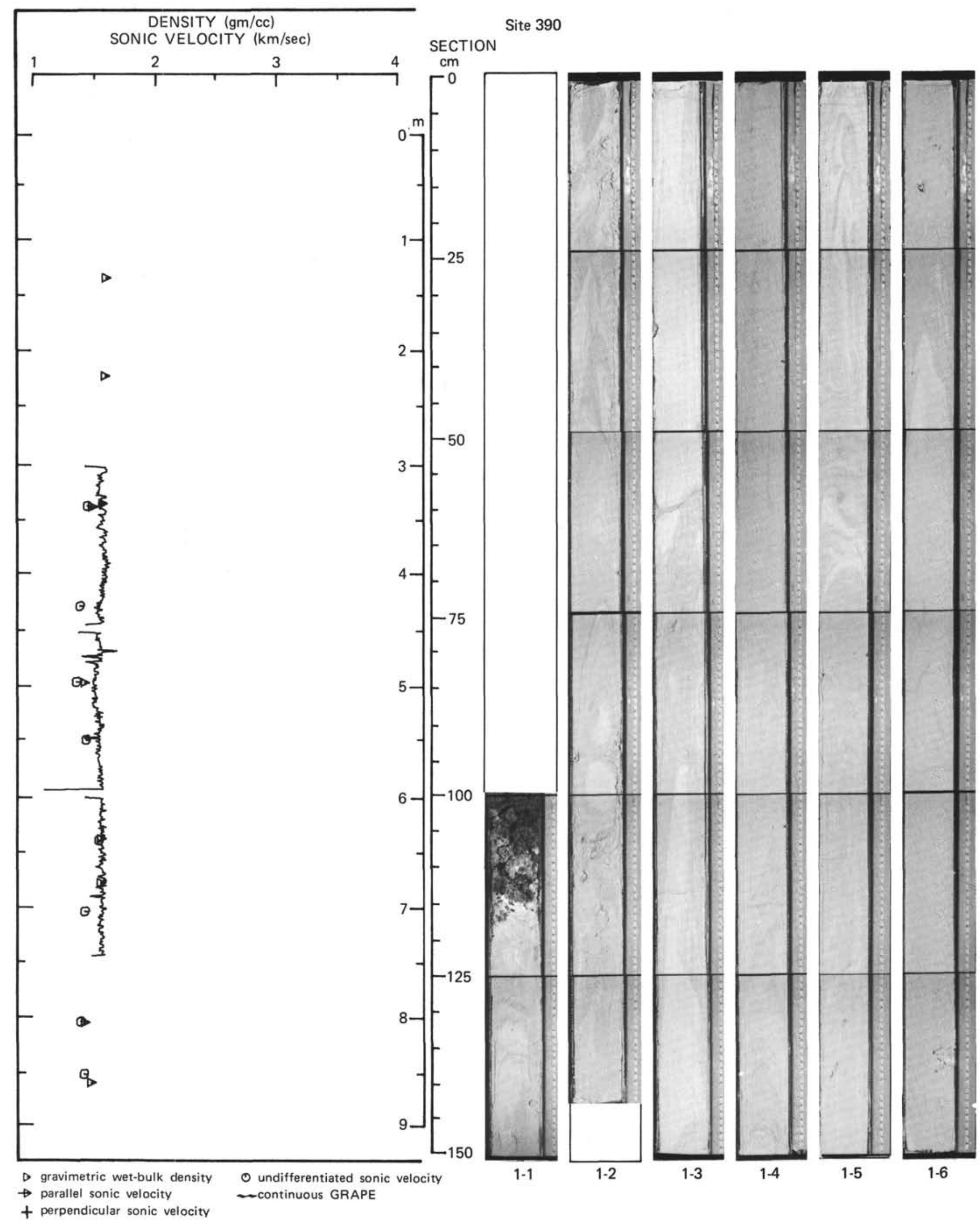




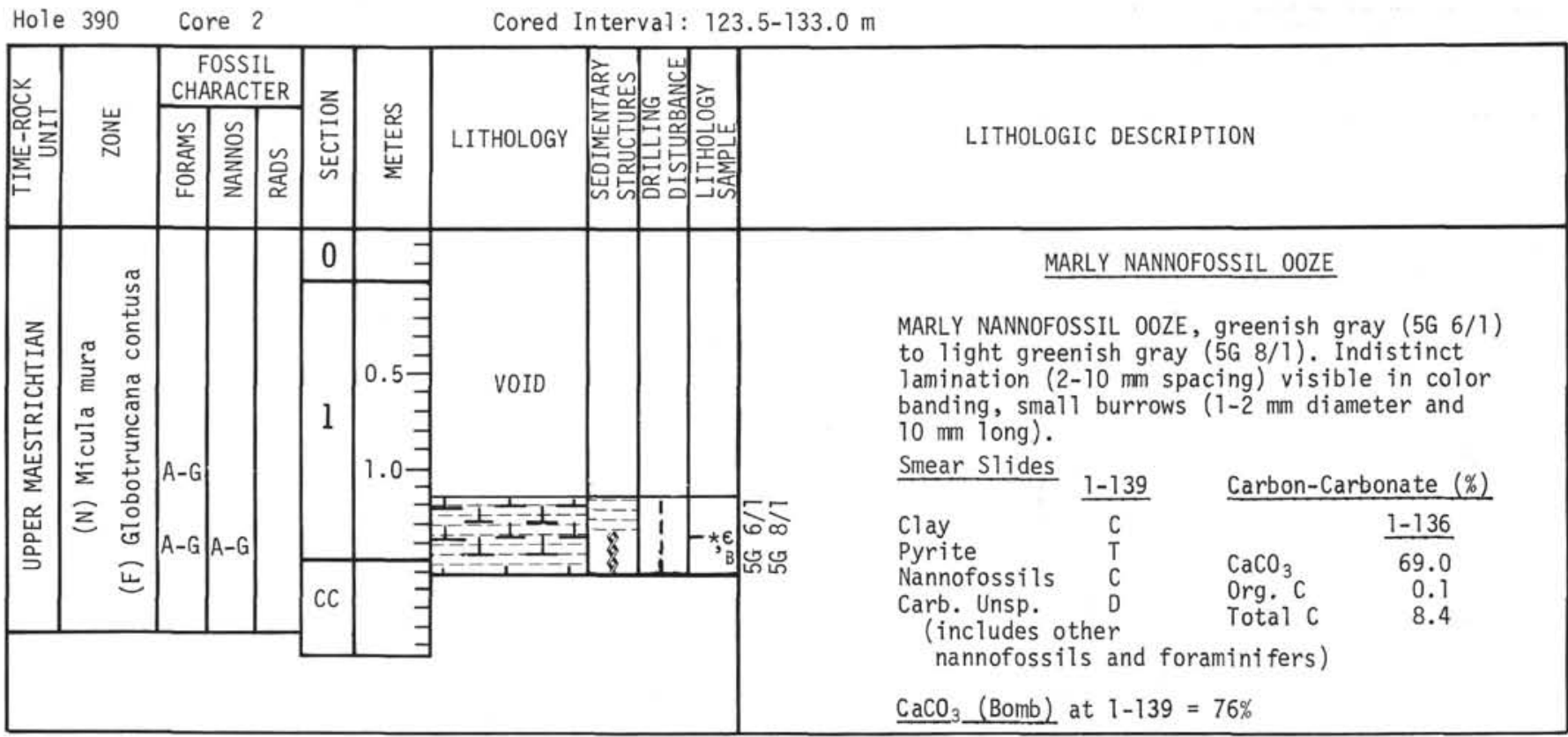




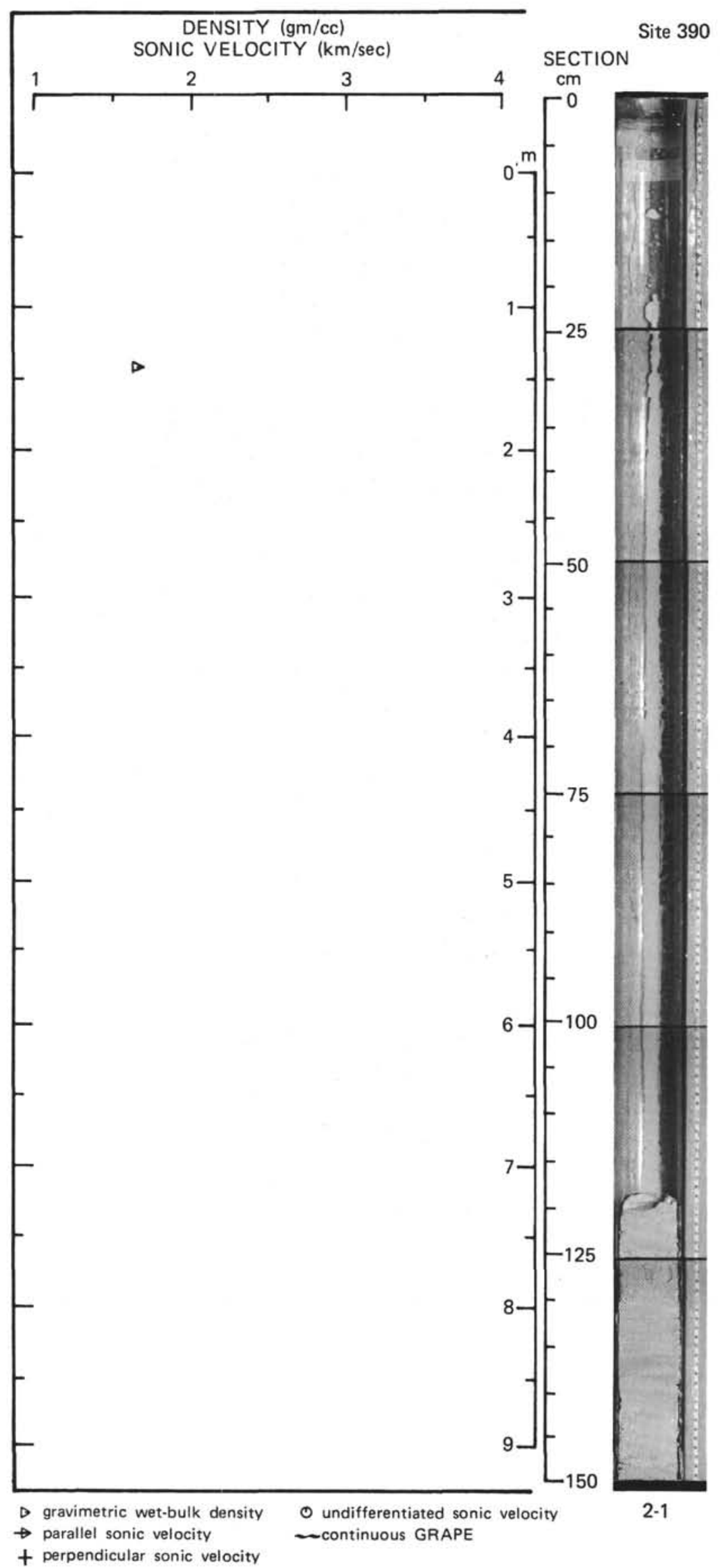




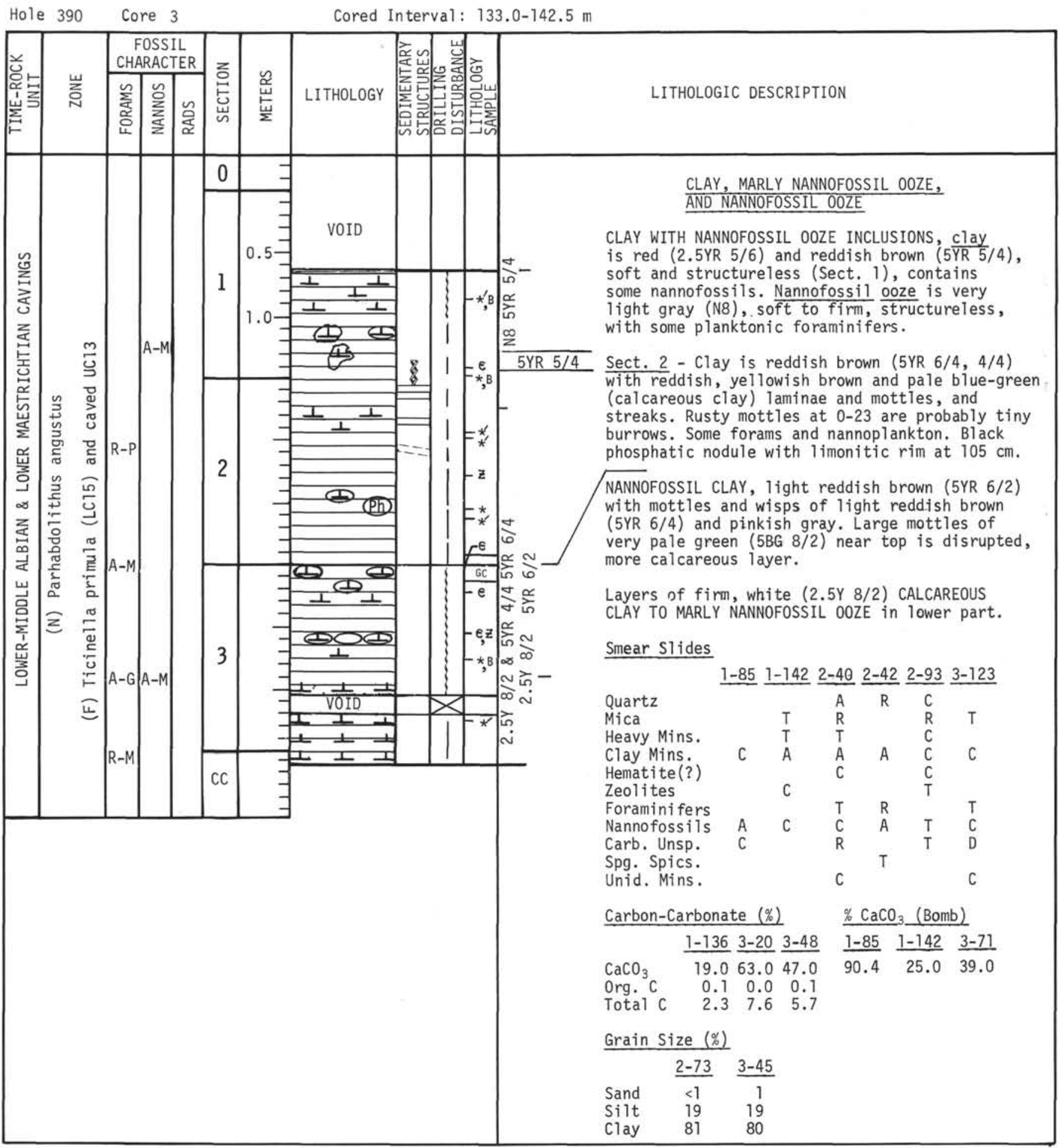




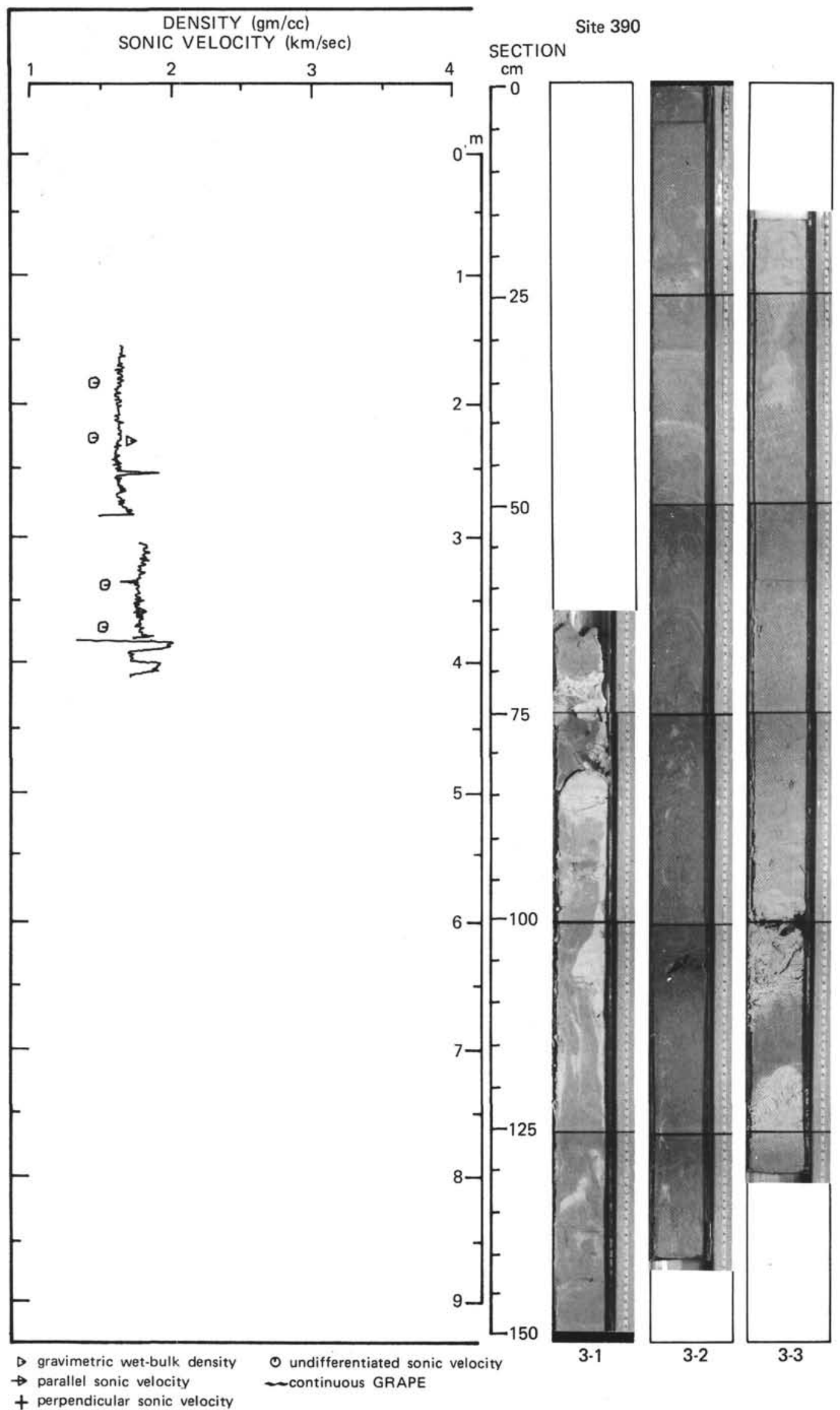




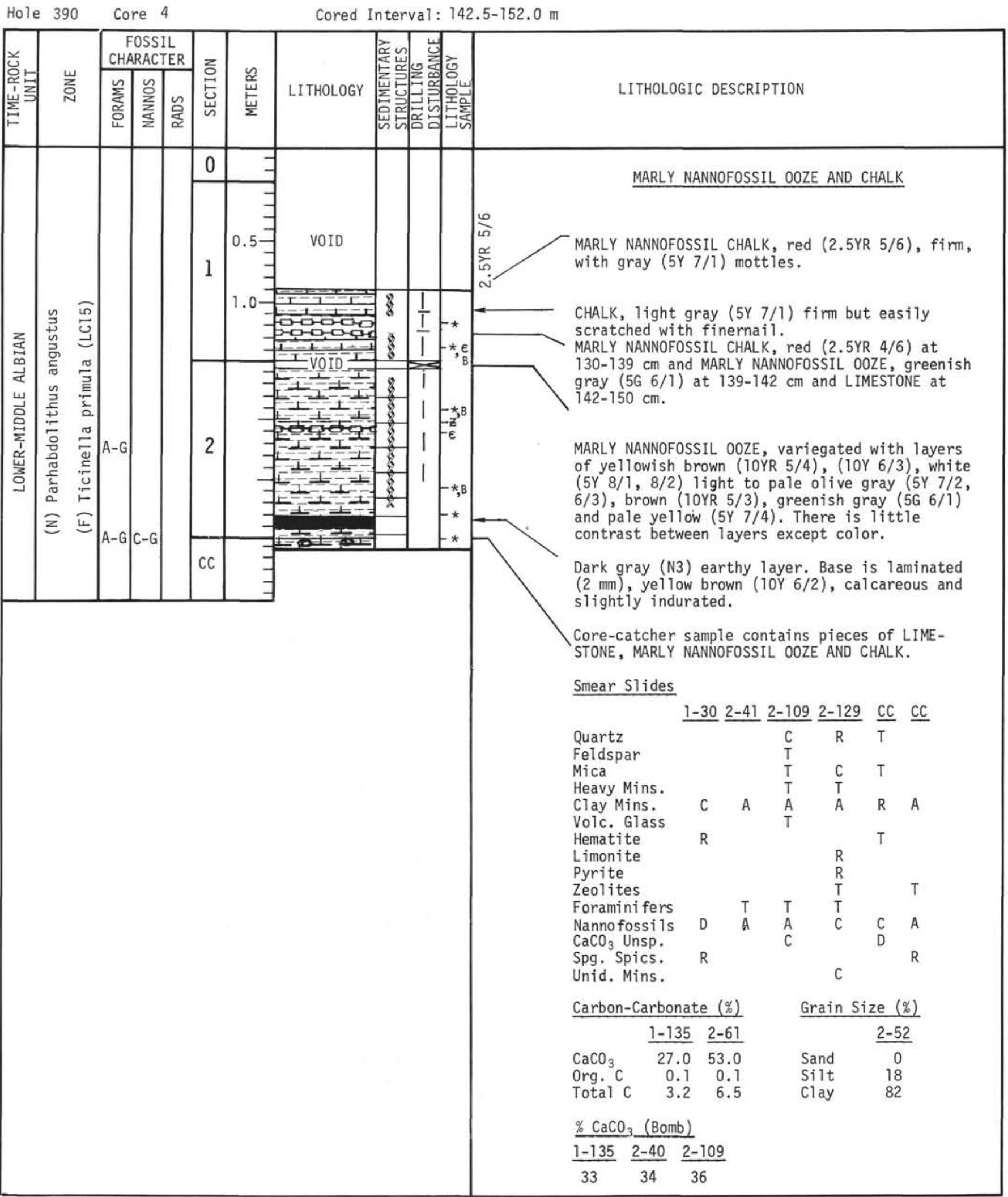




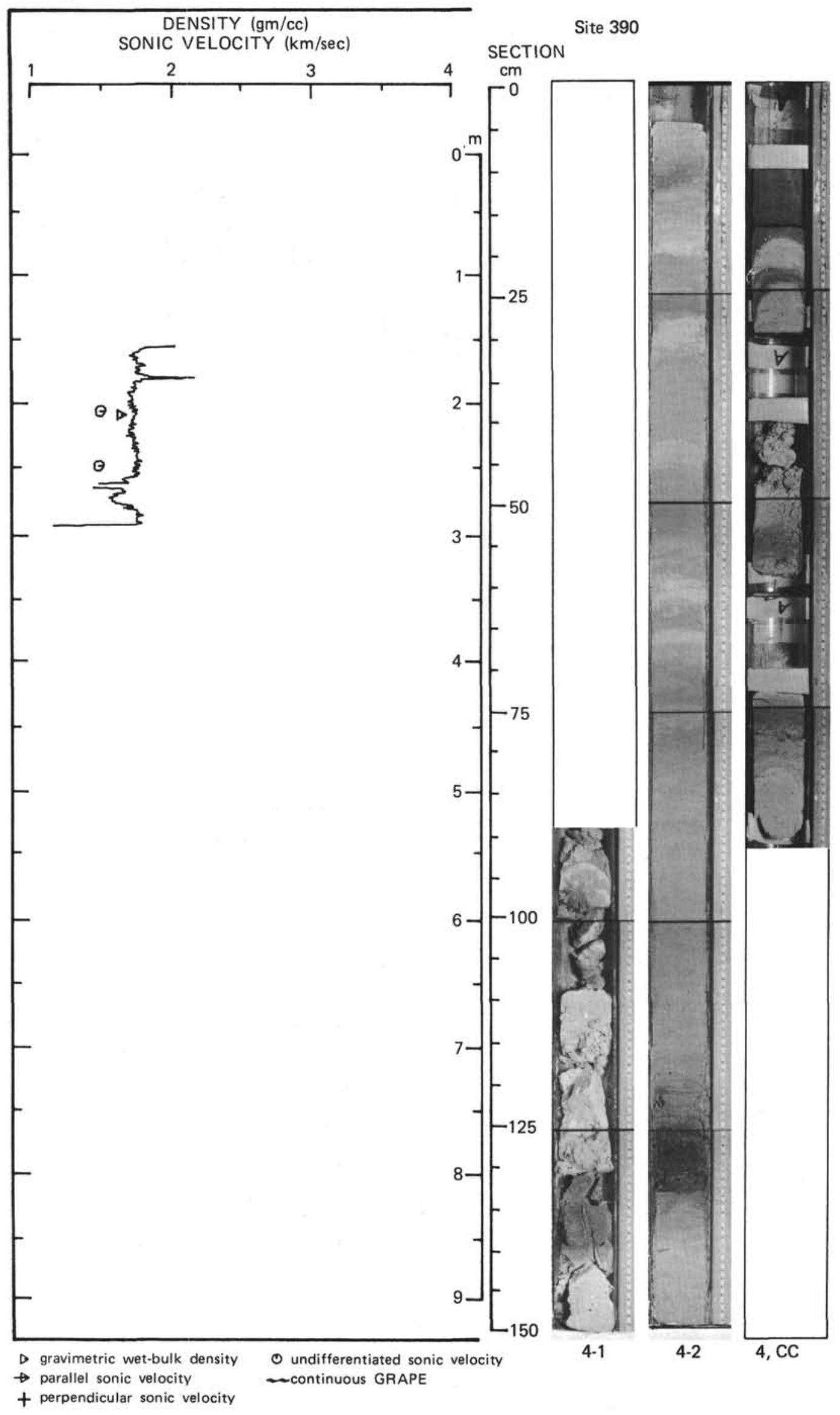




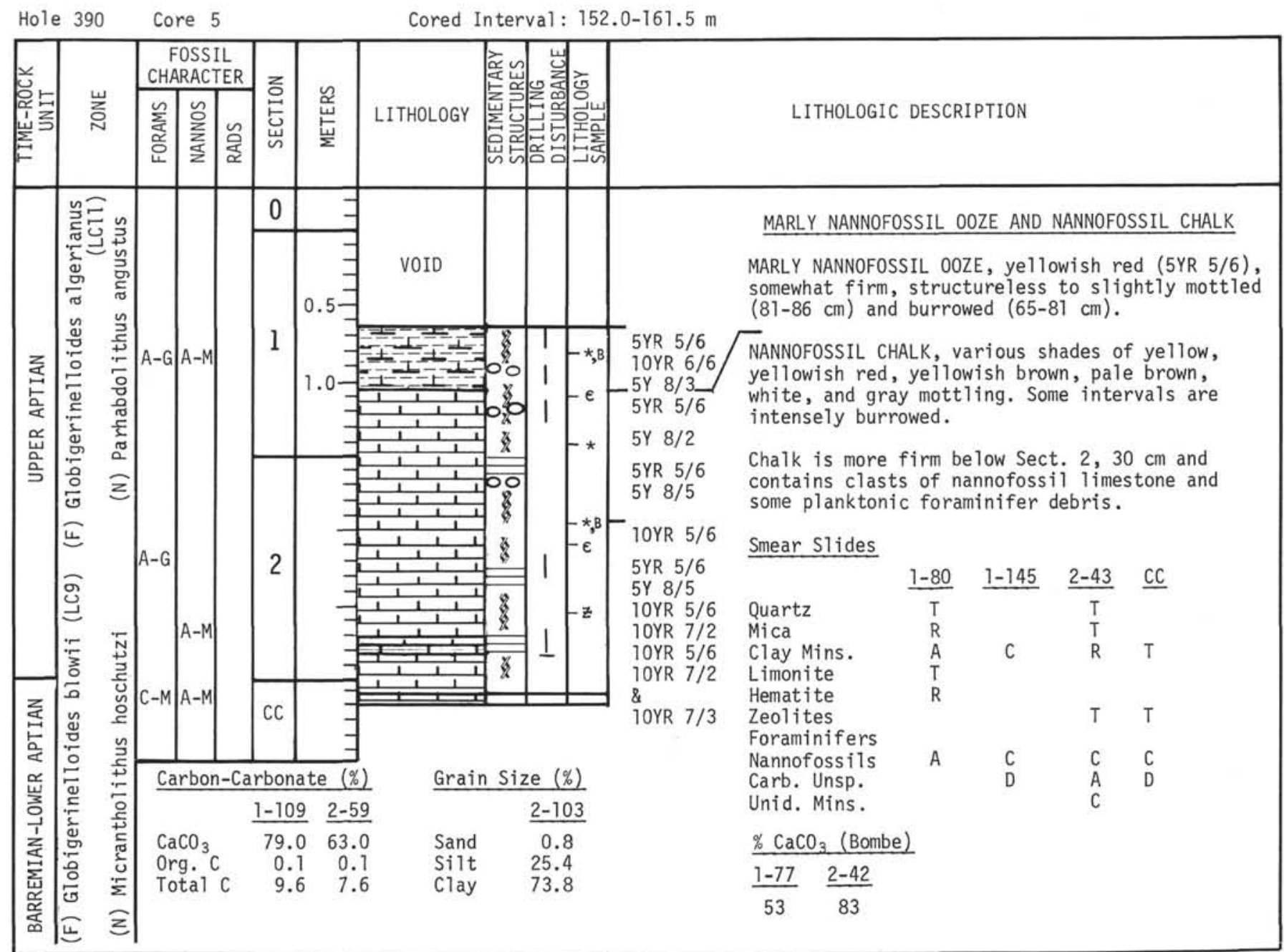

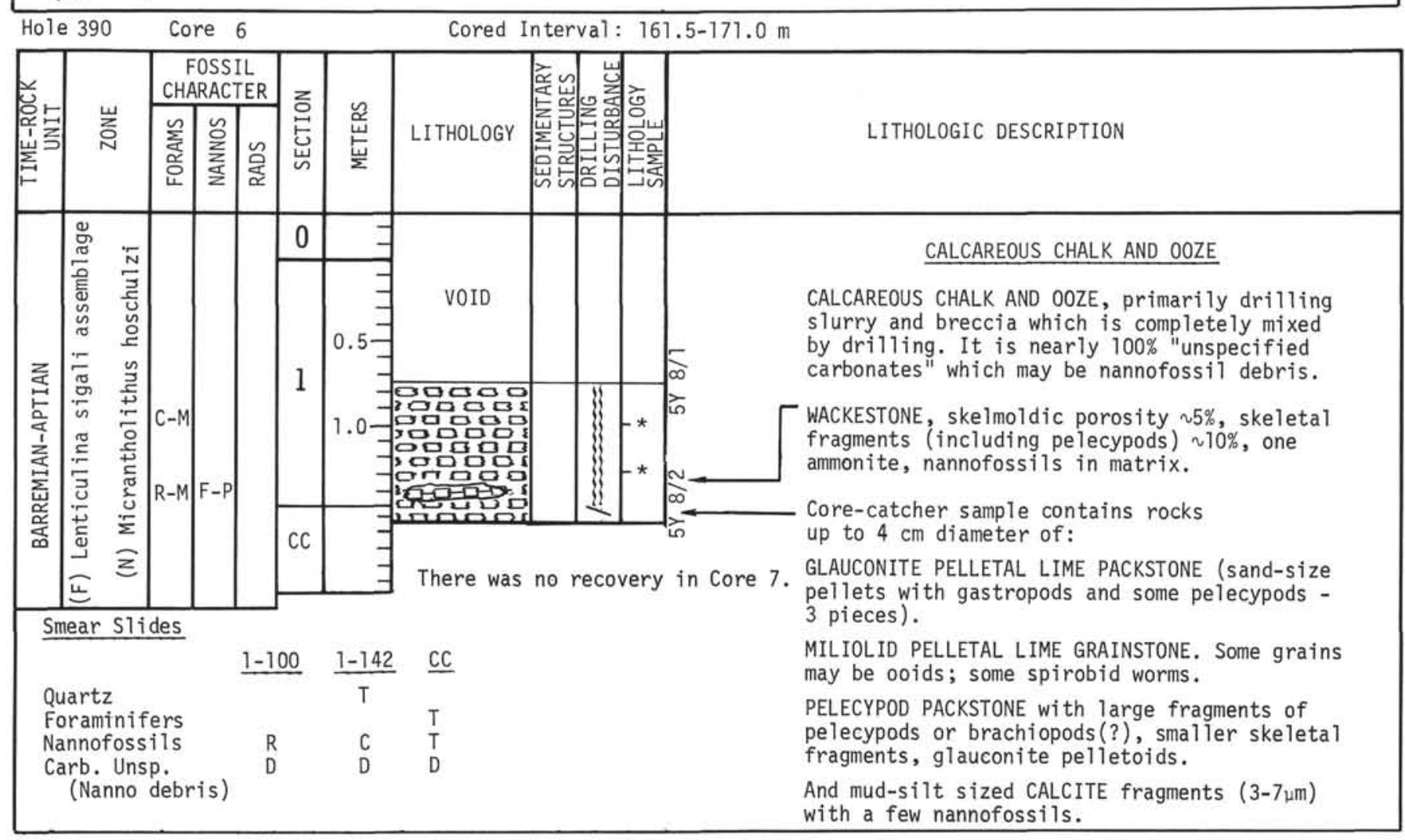




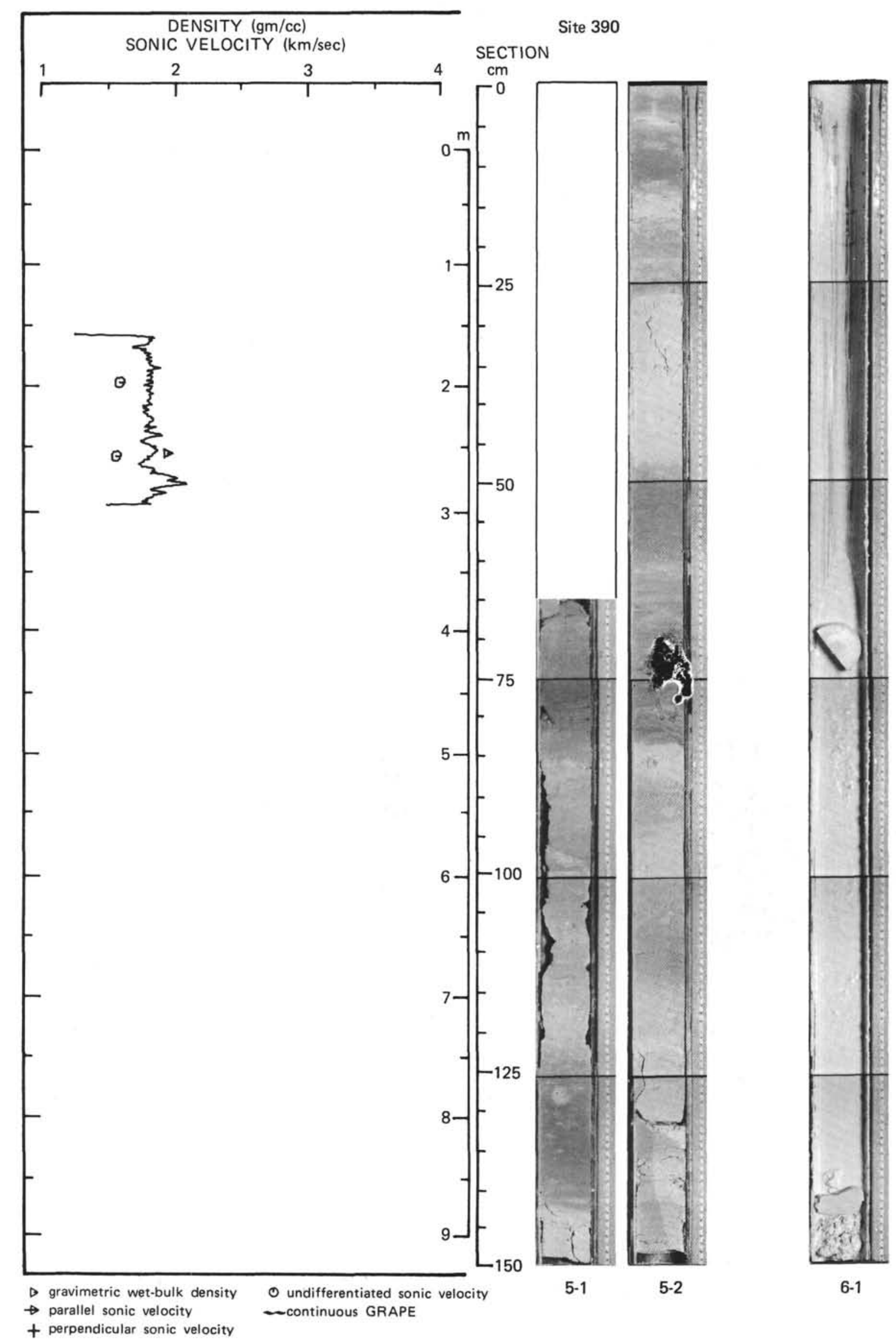




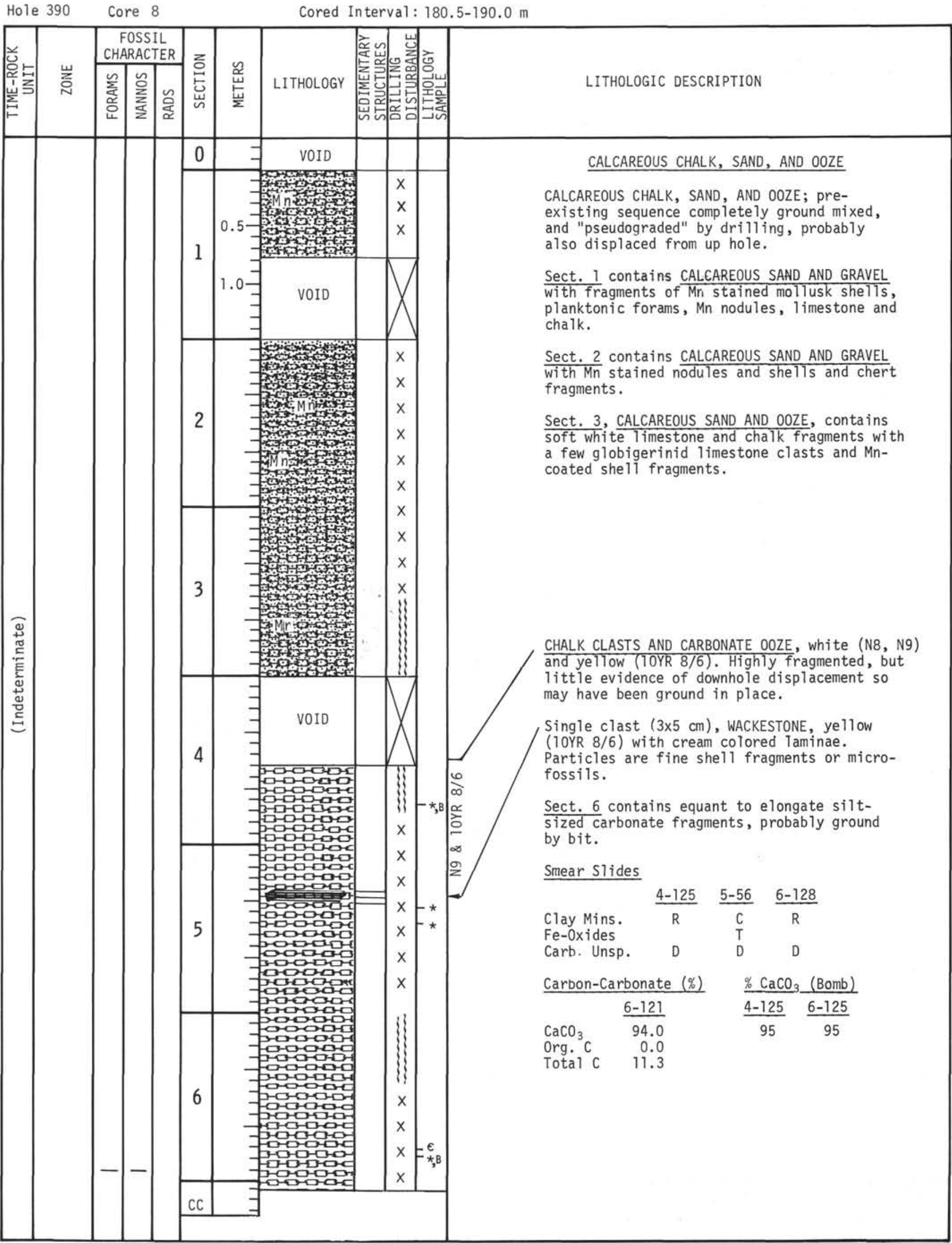




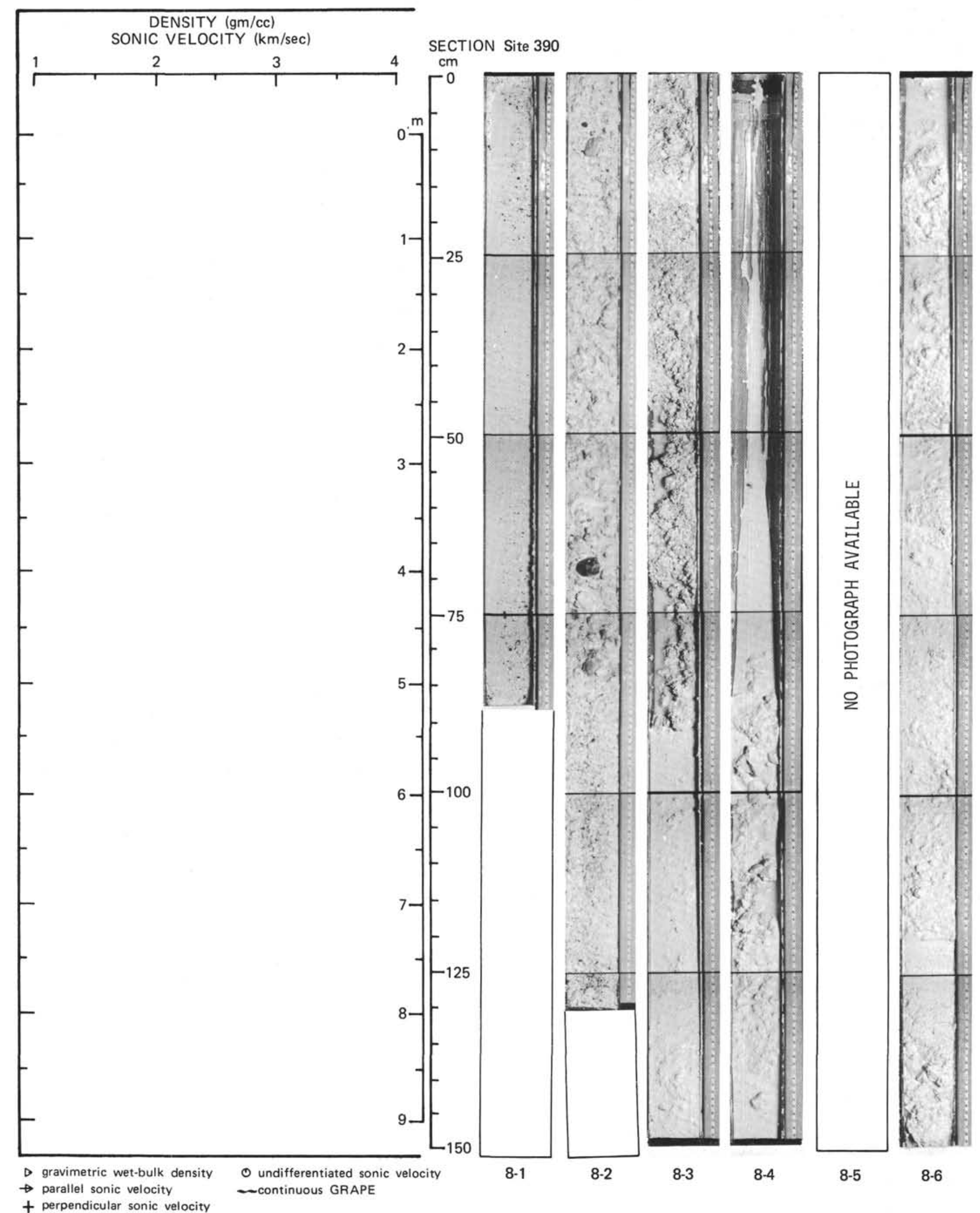




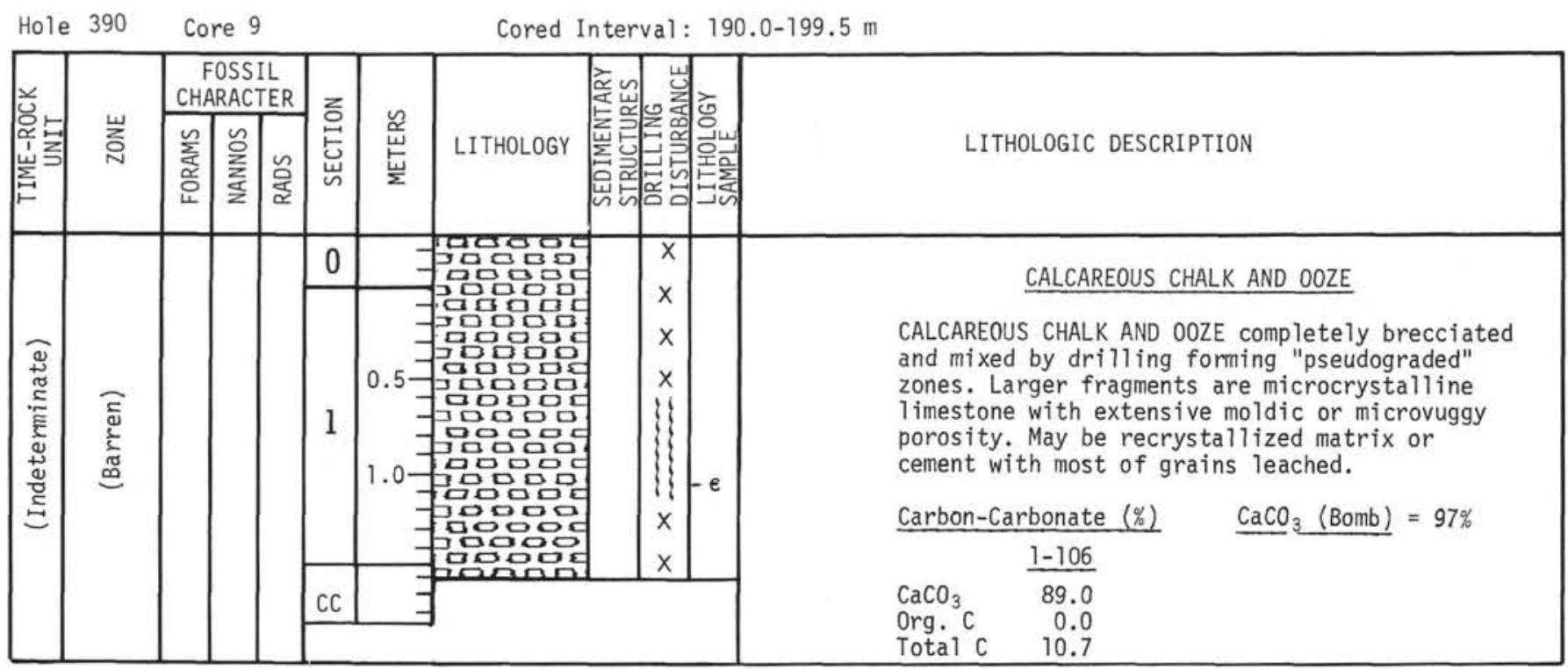

\begin{tabular}{|c|c|c|c|c|c|c|c|c|c|c|c|}
\hline \multirow{2}{*}{ 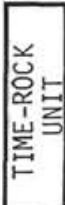 } & \multirow[b]{2}{*}{ 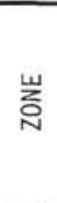 } & \multicolumn{3}{|c|}{$\begin{array}{c}\text { FOSSIL } \\
\text { CHARACTER }\end{array}$} & \multirow{2}{*}{ 孞 } & \multirow[b]{2}{*}{ 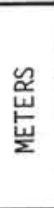 } & \multirow[b]{2}{*}{ LITHOLOGY } & \multirow{2}{*}{ 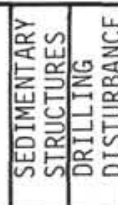 } & \multirow{2}{*}{ 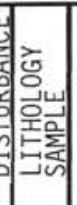 } & & \multirow[b]{2}{*}{ LITHOLOGIC DESCRIPTION } \\
\hline & & 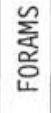 & 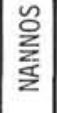 & 芒 & & & & & & & \\
\hline & \multirow{3}{*}{ 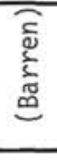 } & & & & & & $\Leftrightarrow$ 郝 & $\mathrm{x}$ & & \multirow[t]{4}{*}{ N9 } & \multirow[b]{2}{*}{ LIMESTONE } \\
\hline & & & & & $\mathrm{CC}$ & & & & & & \\
\hline & & & & & & & & & & & \multirow{2}{*}{$\begin{array}{l}\text { Only recovery from Core } 10 \text { was two small pieces } \\
\text { of WACKESTONE from the core catcher. WACKESTONE } \\
\text { is white ( } \mathrm{N} 9 \text { ), soft, with } 5 \%-10 \% \text { skeletal moldic } \\
\text { porosity. Molds include benthic(?) forams micro- } \\
\text { mollusks. Maximum mold size is } \sim 2 \text { mm. Lined } \\
\text { worm burrows extend several mm into interior of } \\
\text { clasts. }\end{array}$} \\
\hline & & & & & & & & & & & \\
\hline
\end{tabular}




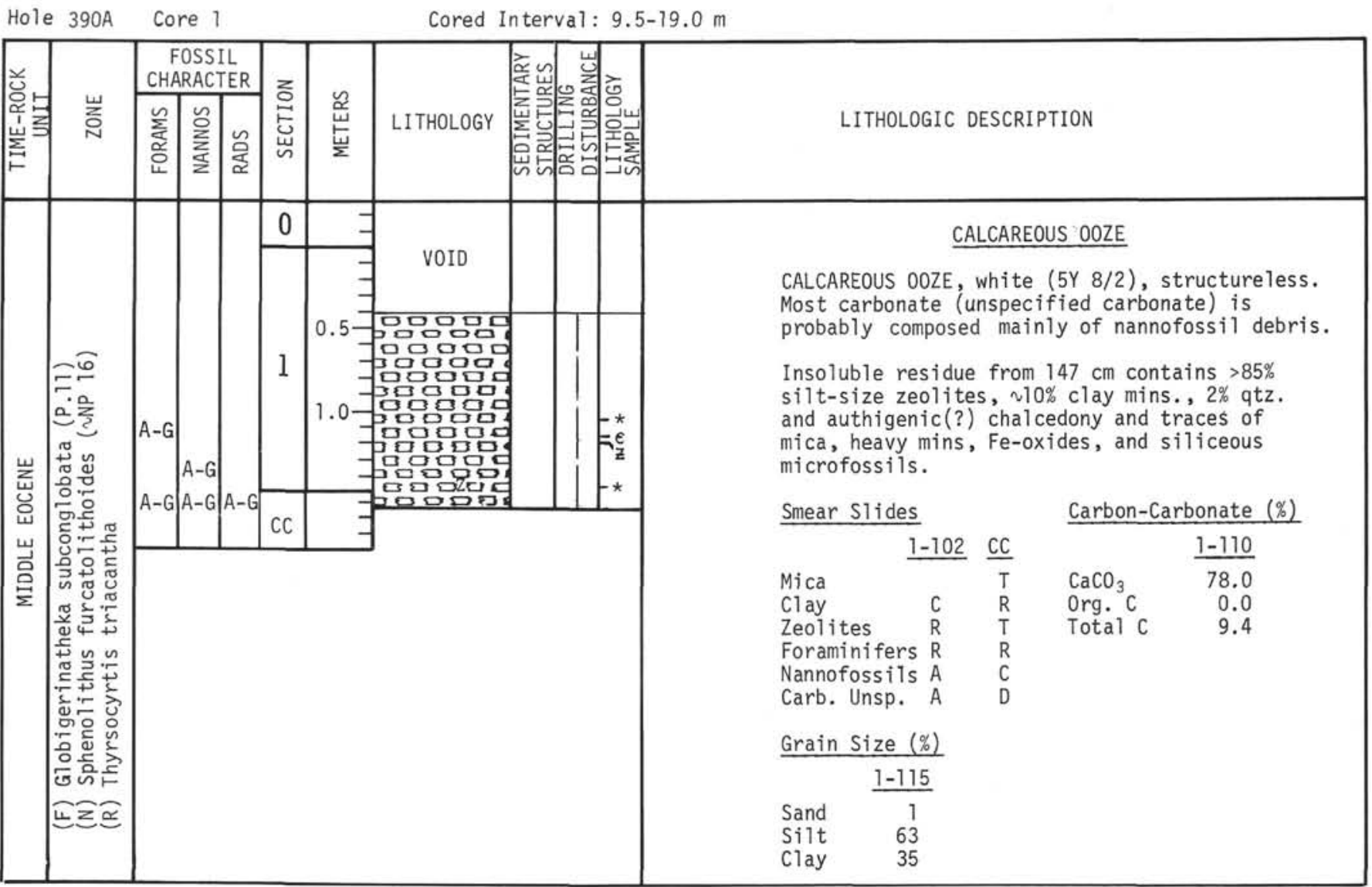

Hole $390 \mathrm{~A}$ Core 2 Cored Interval: $19.0-28.5 \mathrm{~m}$

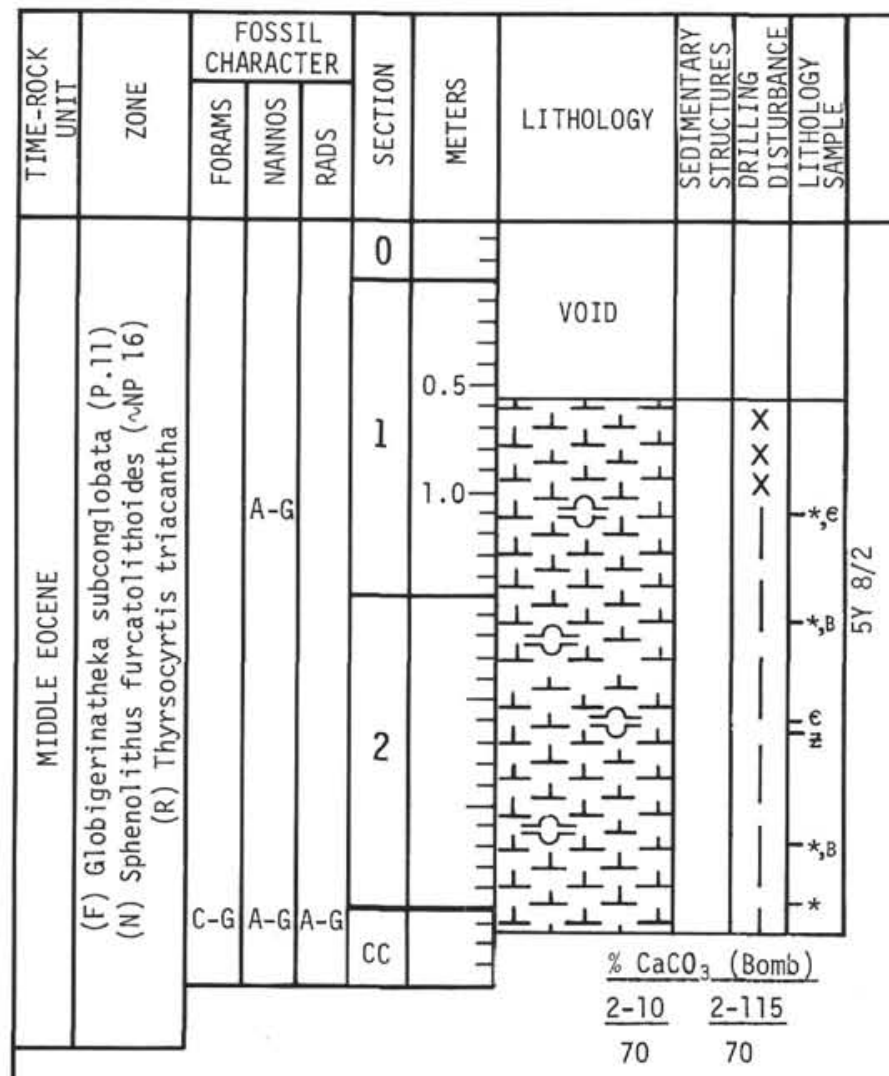

LITHOLOGIC DESCRIPTION

SILICEOUS NANNOFOSSIL OOZE

SILICEOUS NANNOFOSSIL OOZE, white (5Y 8/2), structureless, contains $70 \%$ nannofoss $11 \mathrm{~s}$ and up to $25 \%$ siliceous microfossils.

Smear Slides

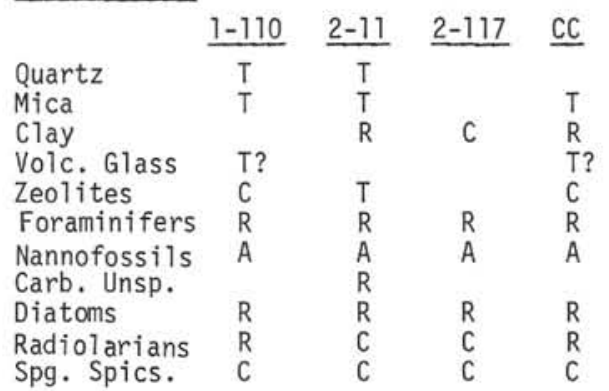

Carbon-Carbonate (\%) Grain Size (\%)

$\begin{array}{lrrrrr} & \frac{1-107}{71.0} & \frac{2-58}{67.0} & & \text { Sand } & \frac{2-60}{2} \\ \mathrm{CaCO}_{3} & 71.0 & 0.0 & \text { Silt } & 58 \\ \text { Org. } \mathrm{C} & 0.0 & 0.0 & \text { Clay } & 39\end{array}$




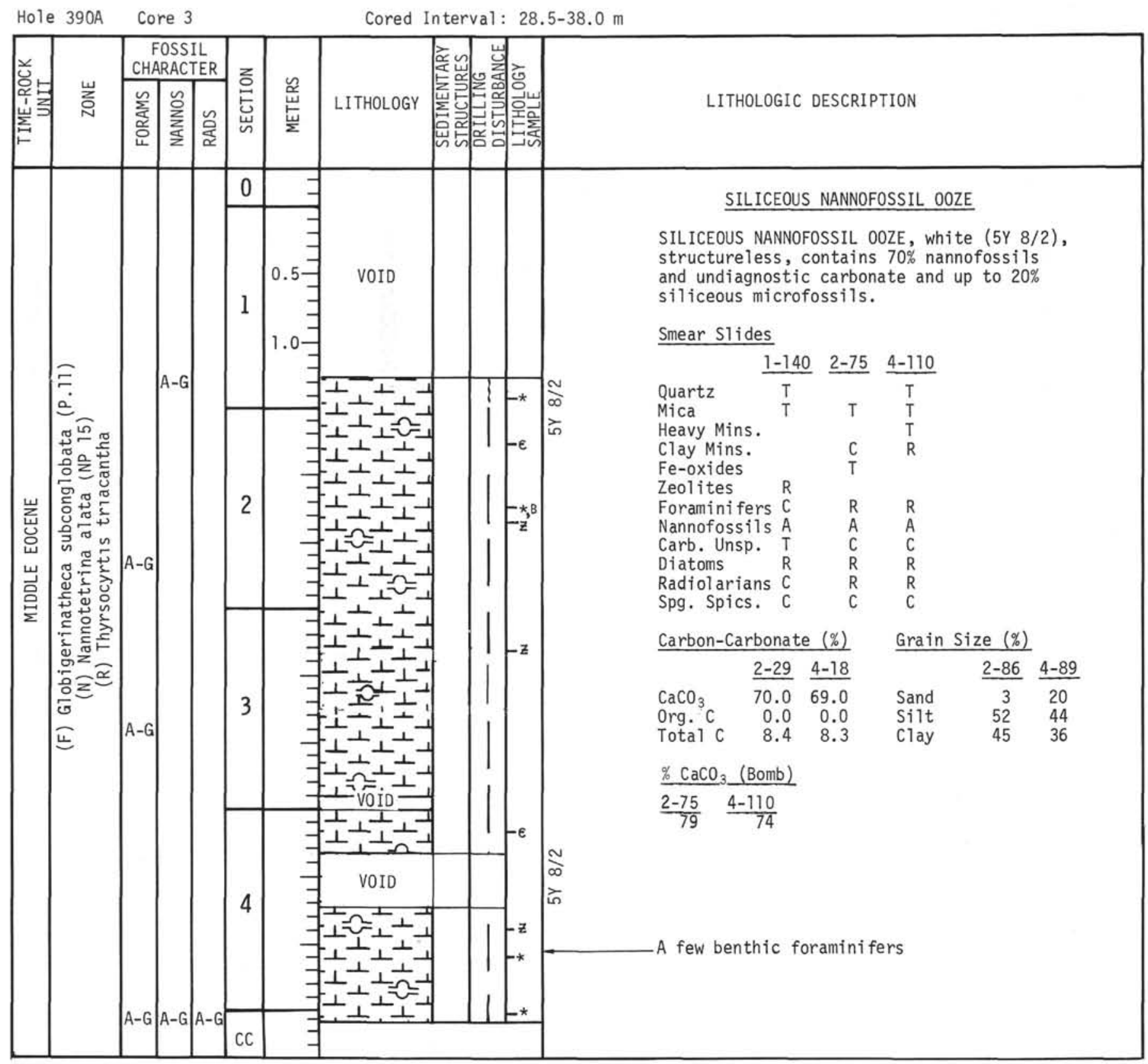




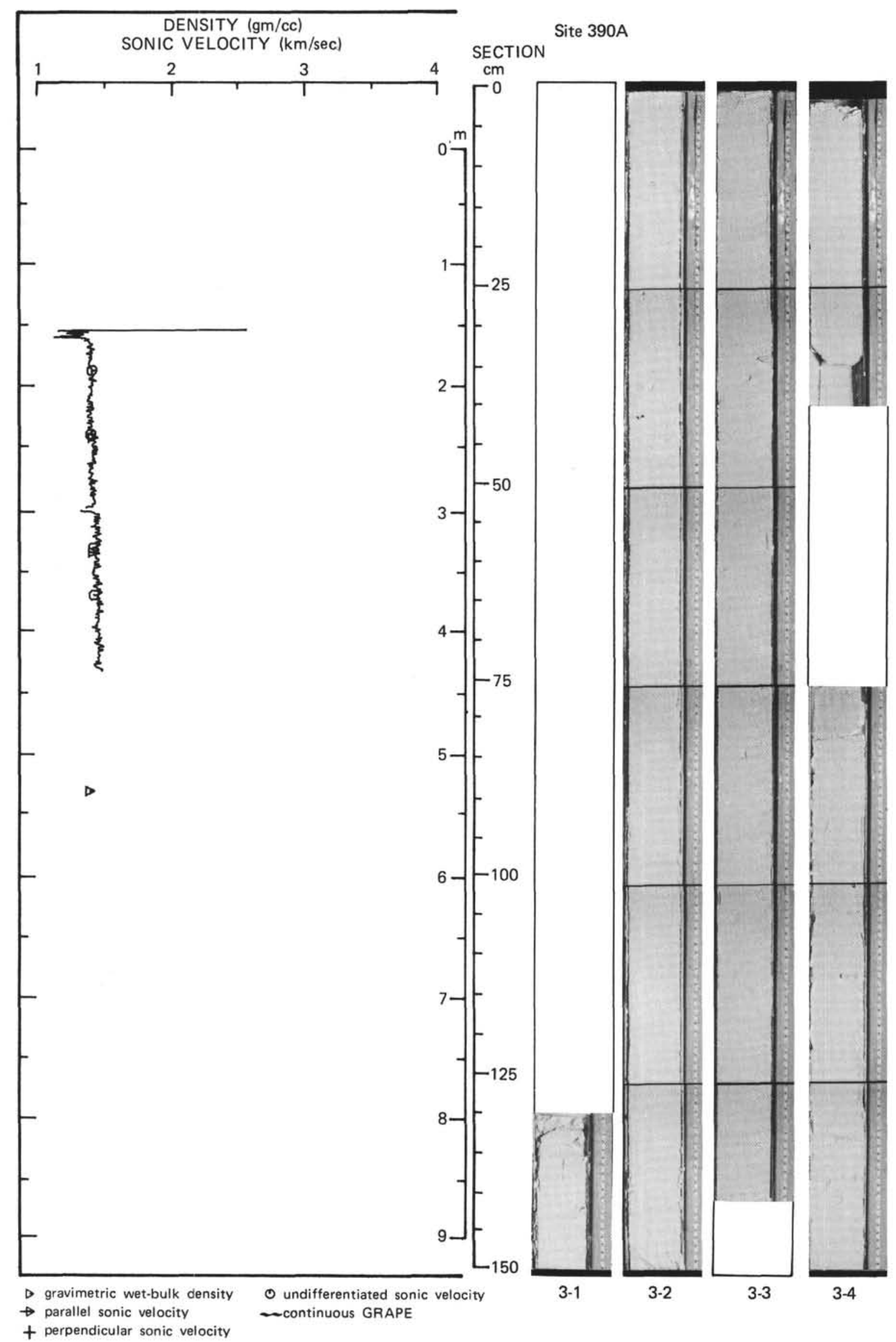




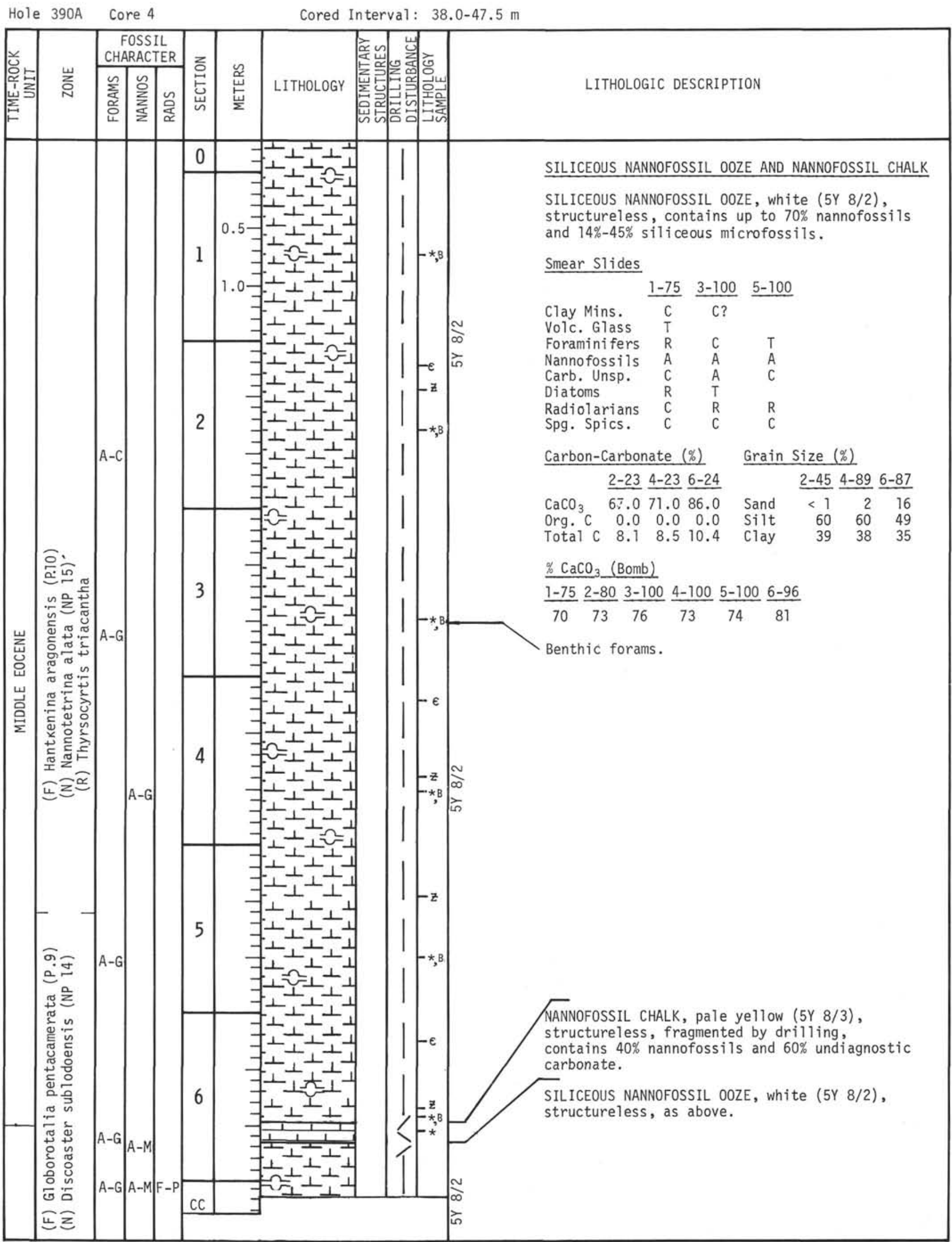




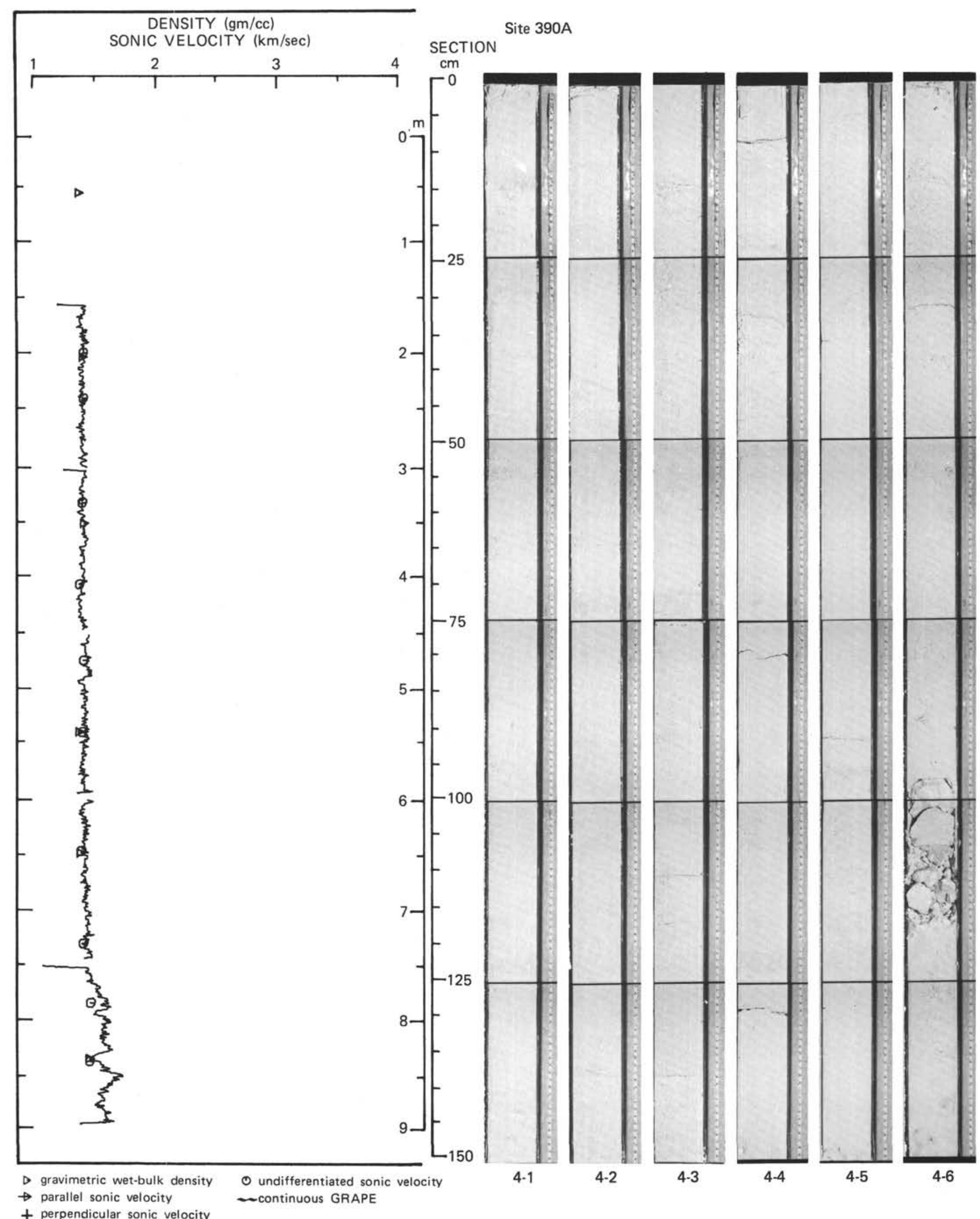




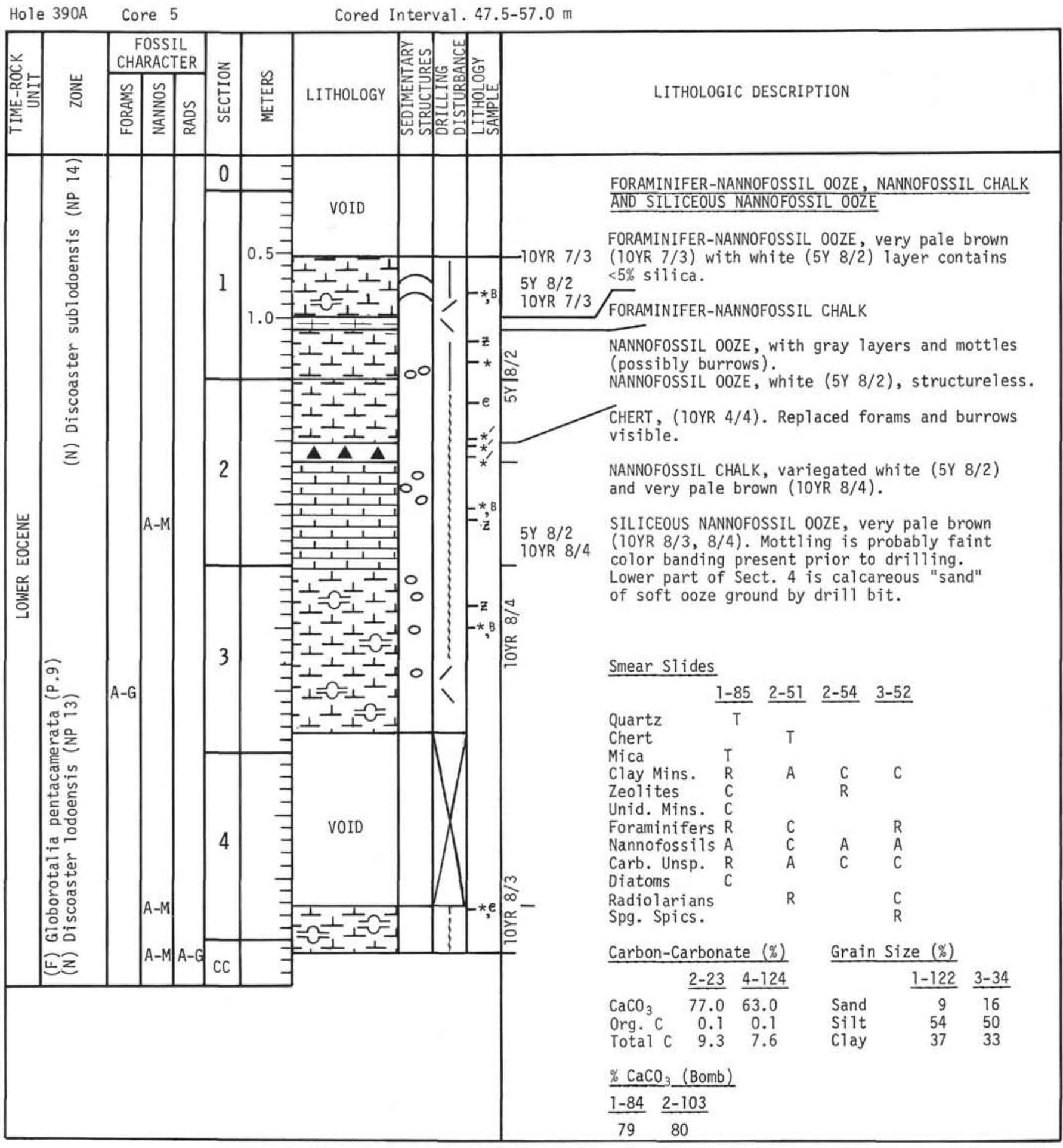




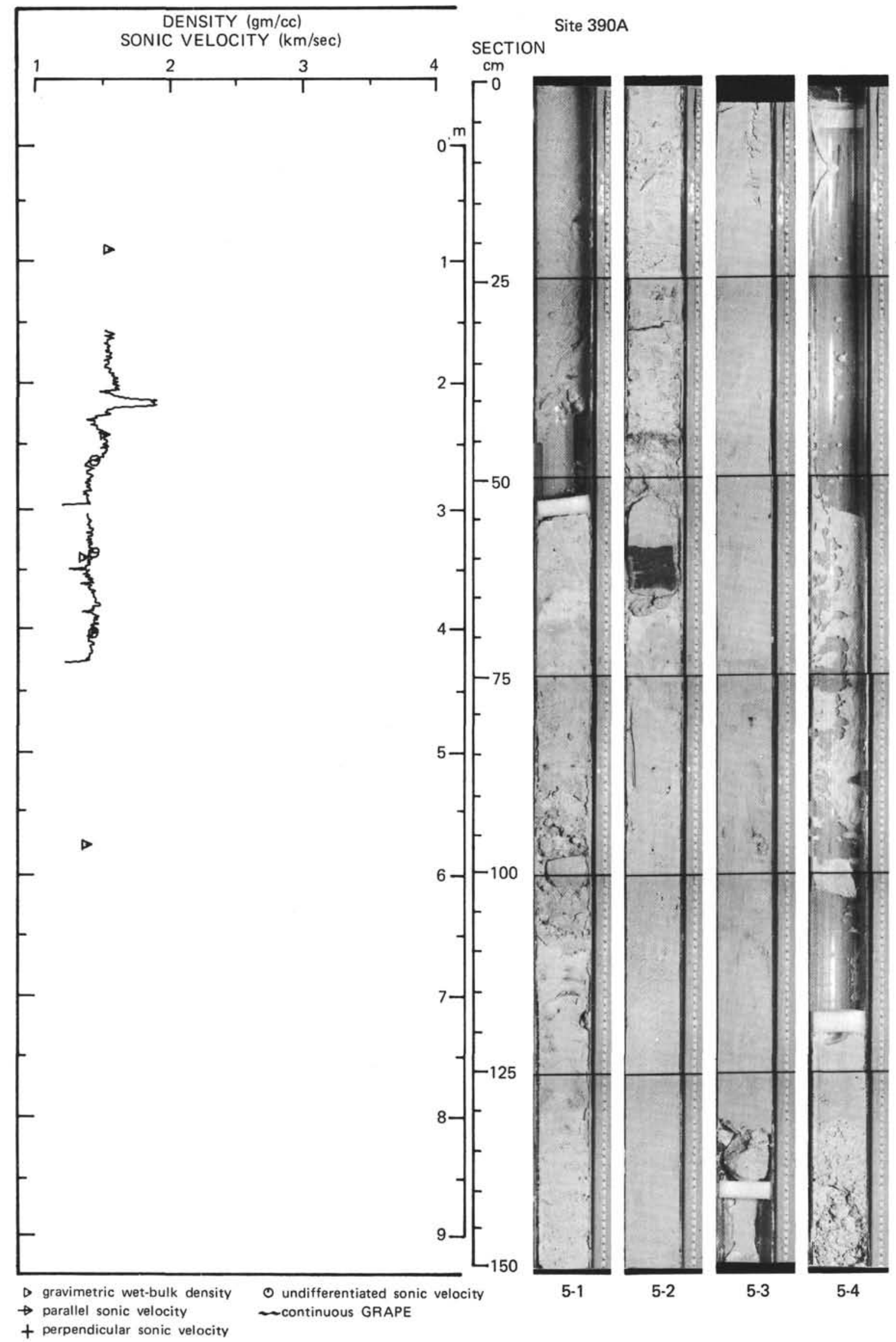




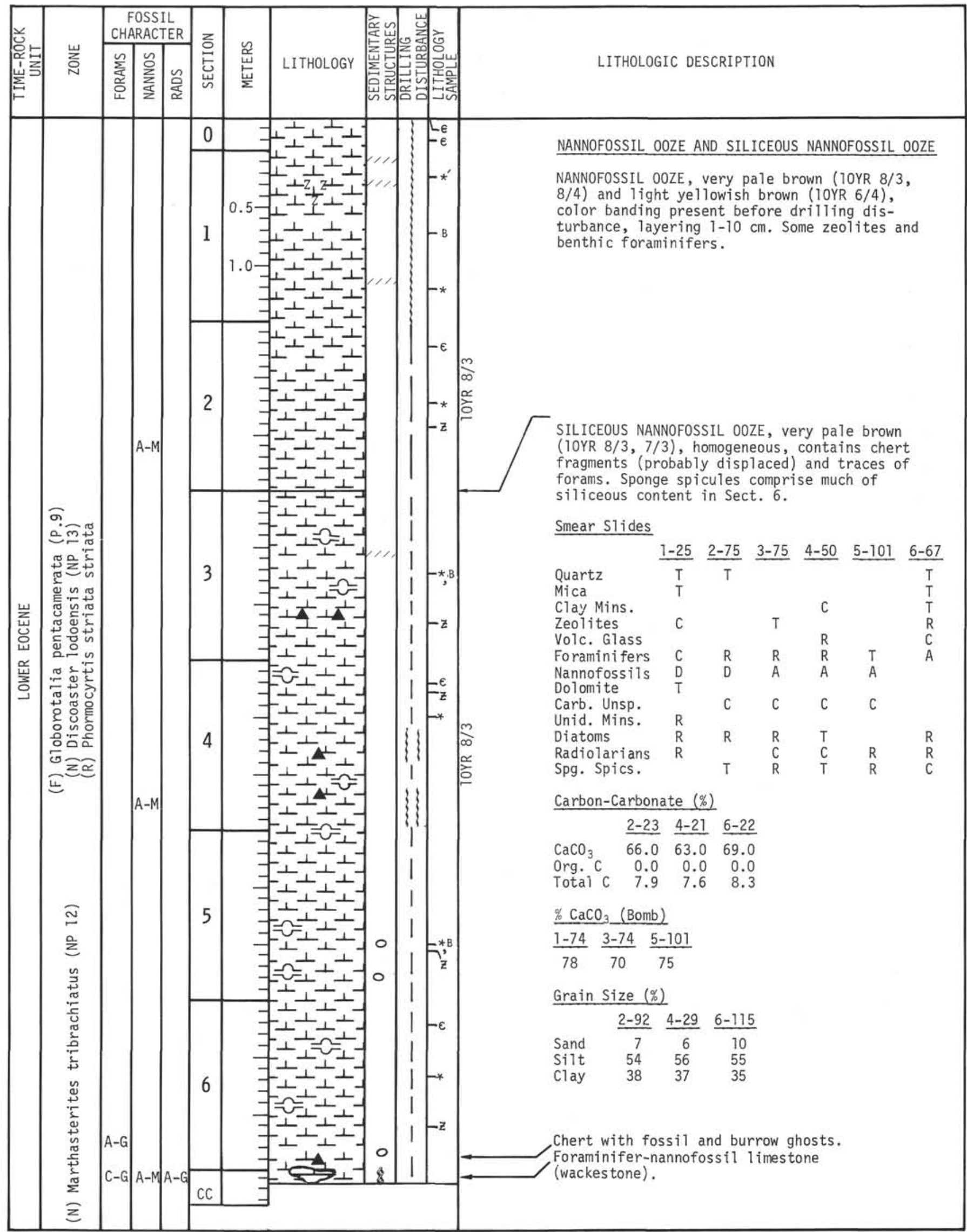




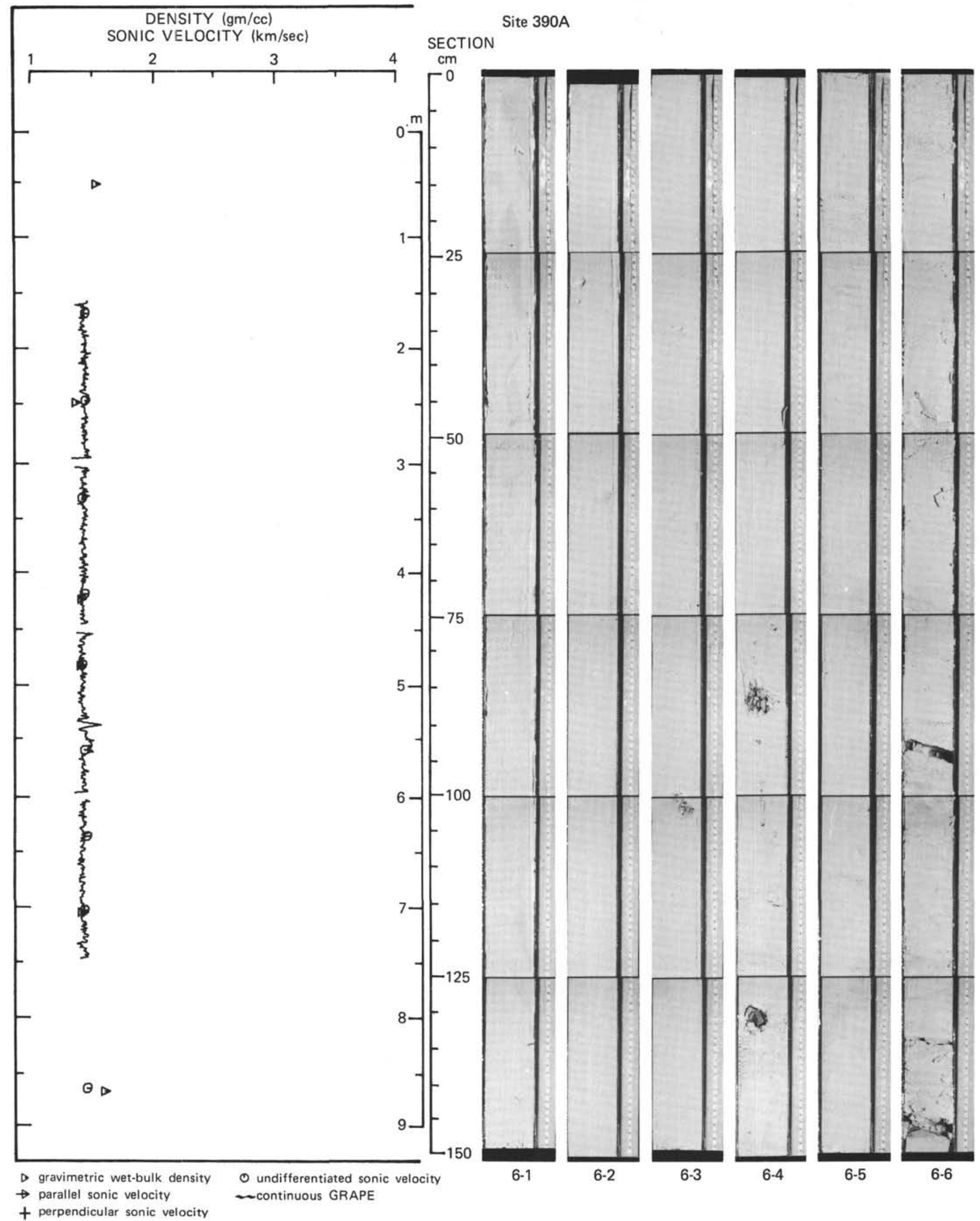




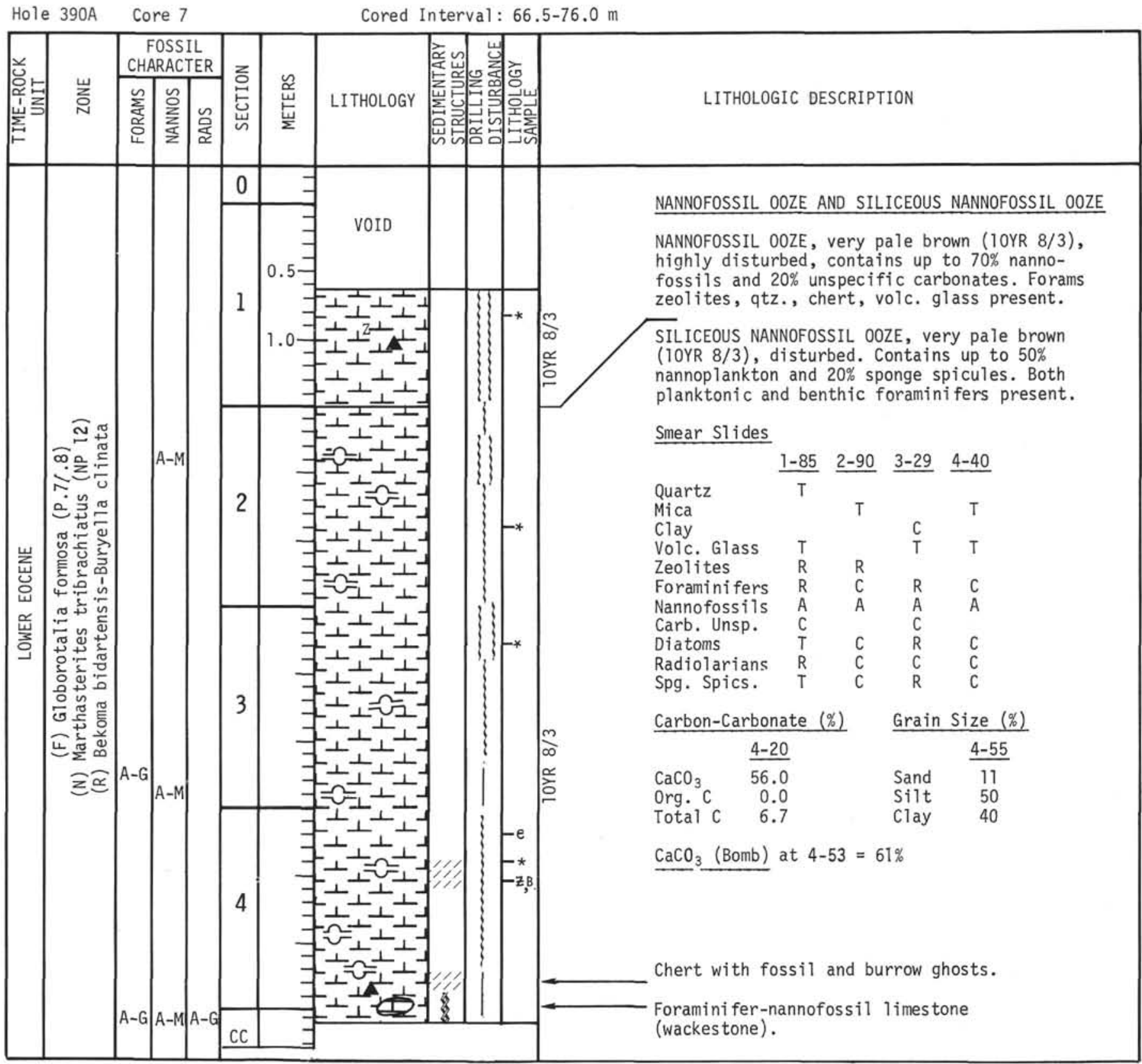




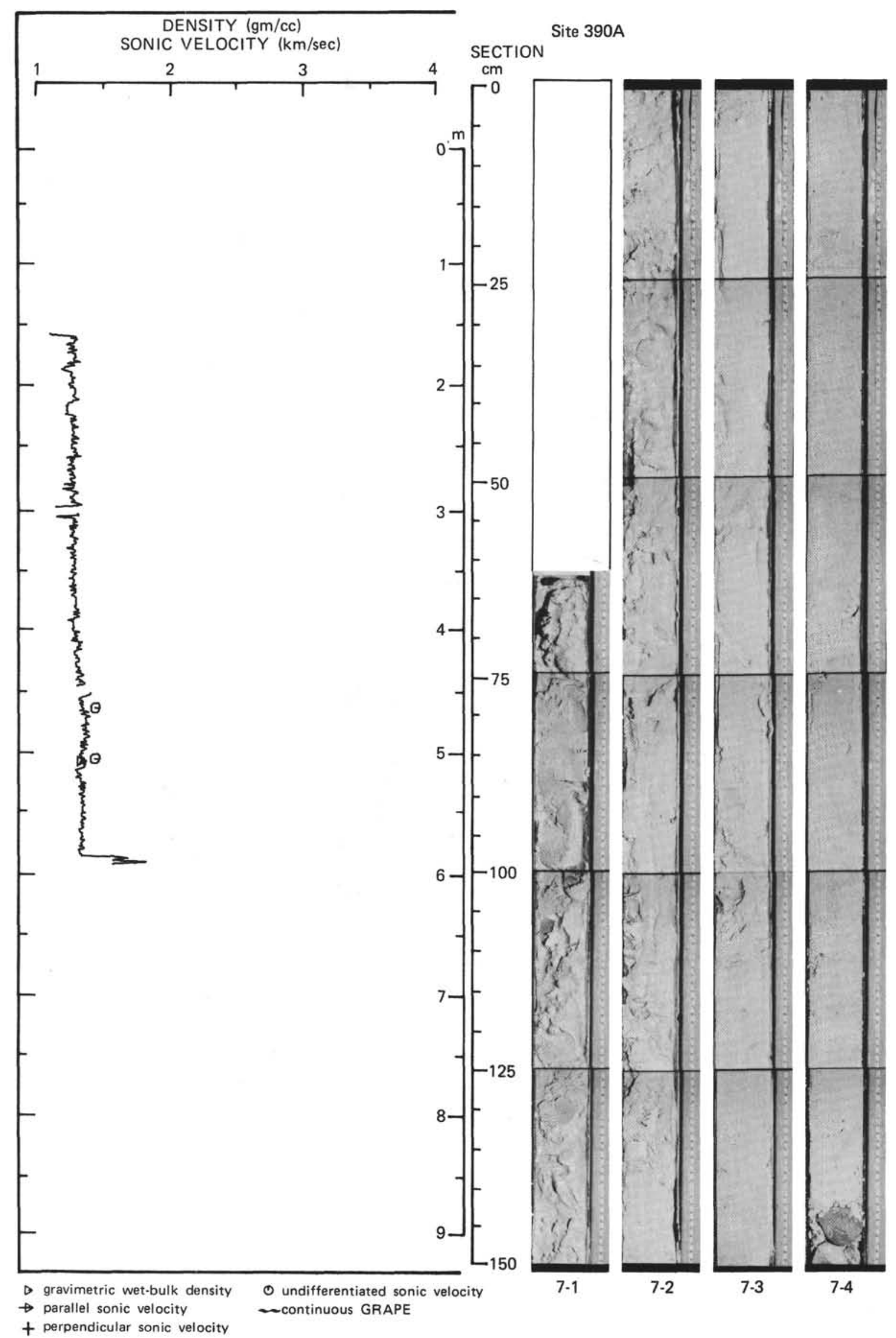




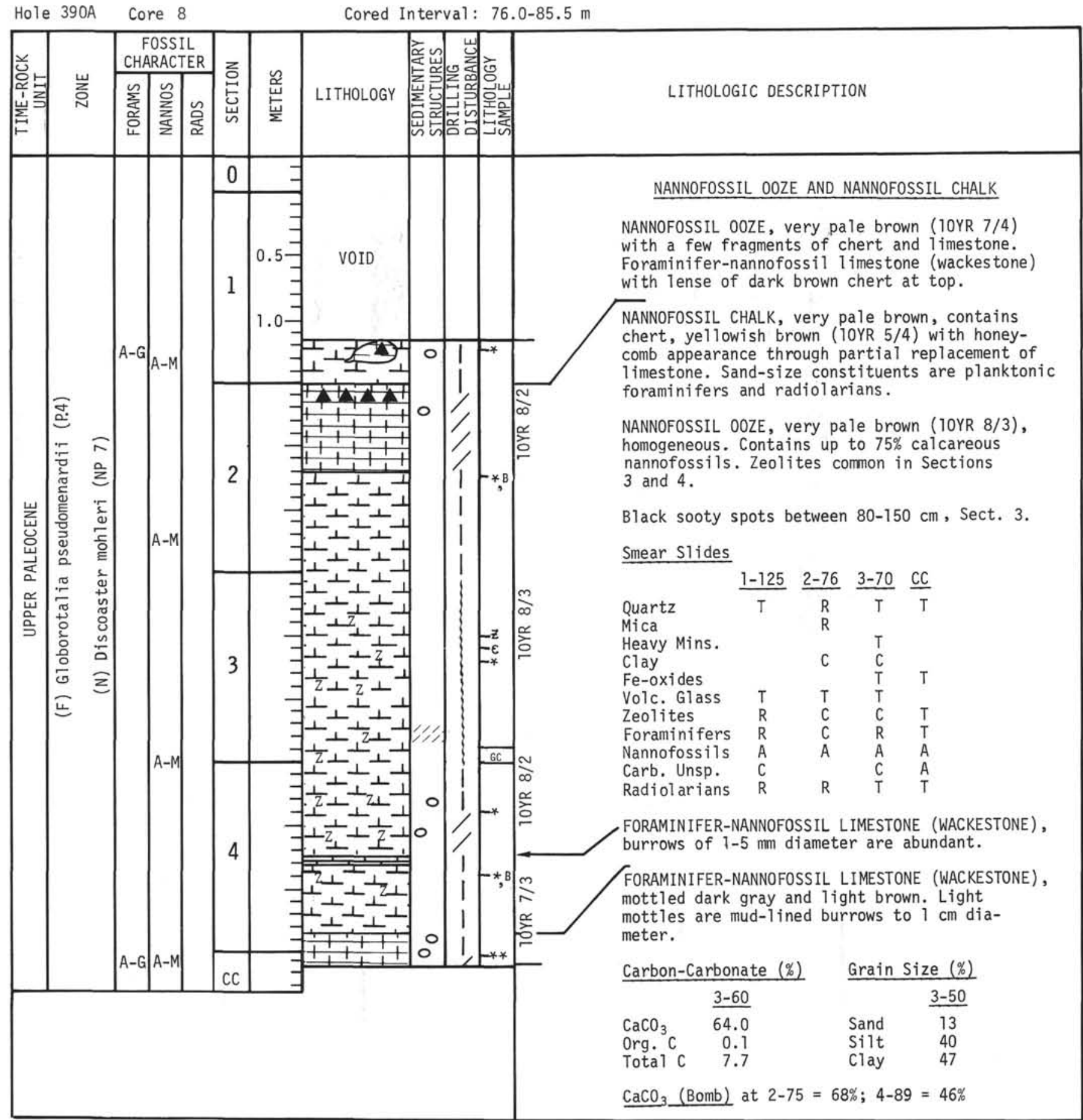




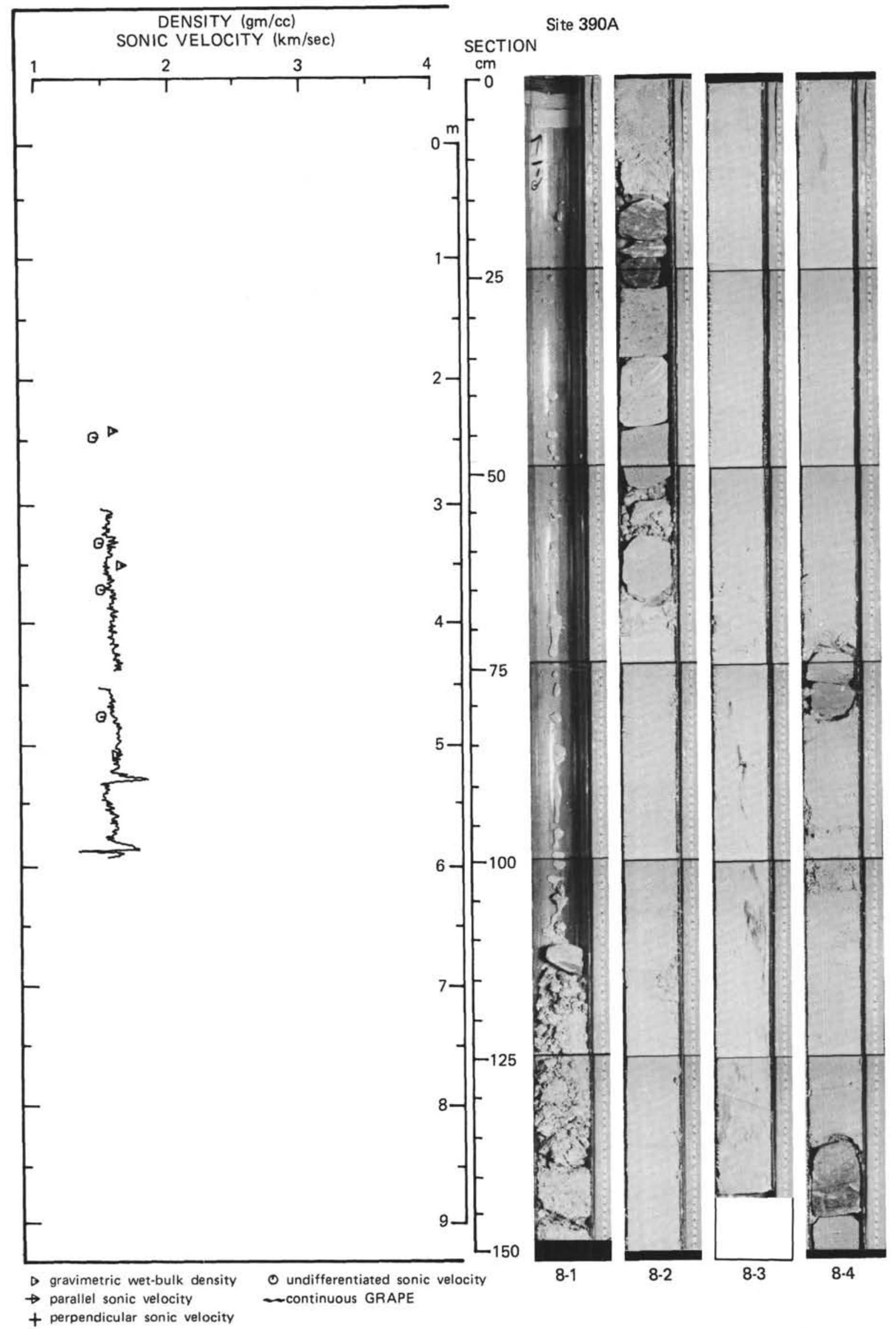


Hole 390A Core 9

Cored Interval: $85.5-95.0 \mathrm{~m}$

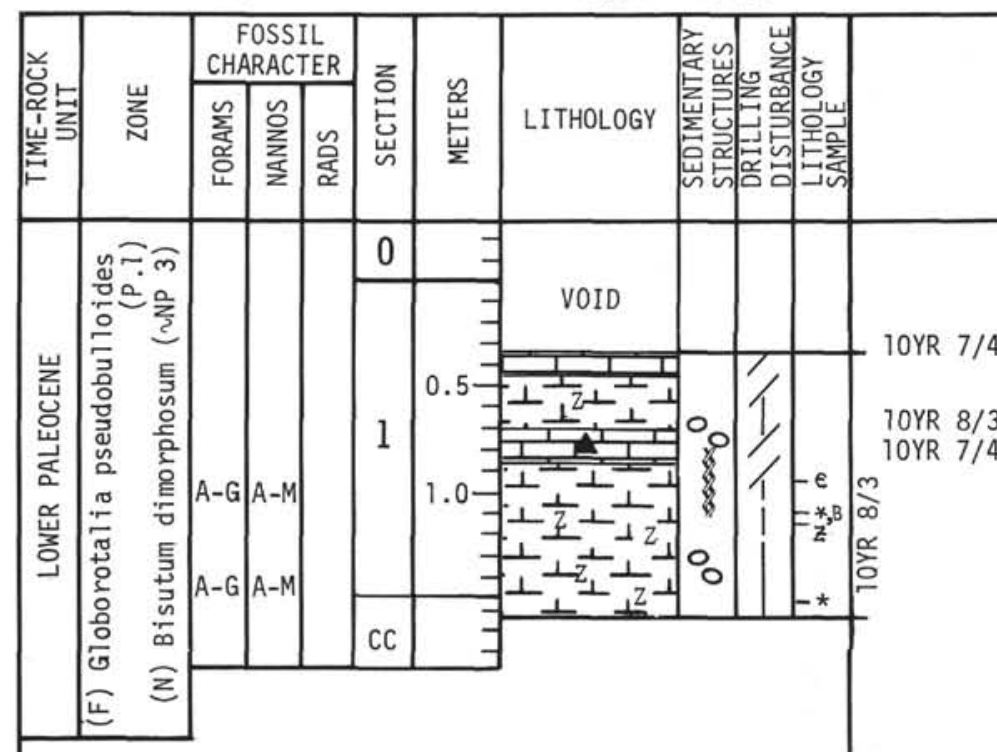

LITHOLOGIC DESCRIPTION

\section{ZEOLITIC NANNOFOSSIL OOZE}

ZEOLITIC NANNOFOSSIL O0ZE, with very pale brown (10YR 7/4) limestone (wackestone) at $37-45 \mathrm{~cm}$ and $70-85 \mathrm{~cm}$. Lower bed has horizontal burrows to $5 \mathrm{~mm}$ diameters. Chert lens has irregular borders and contains ghosts of fossils and burrows.

Smear STides

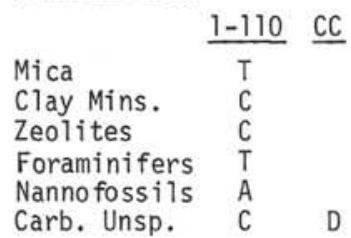

Carbon-Carbonate (\%) Grain Size (\%)

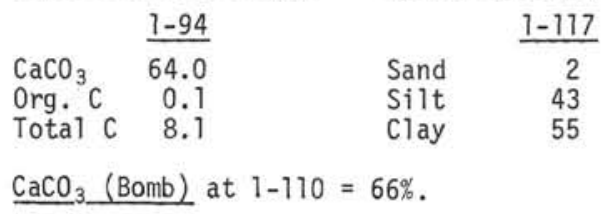




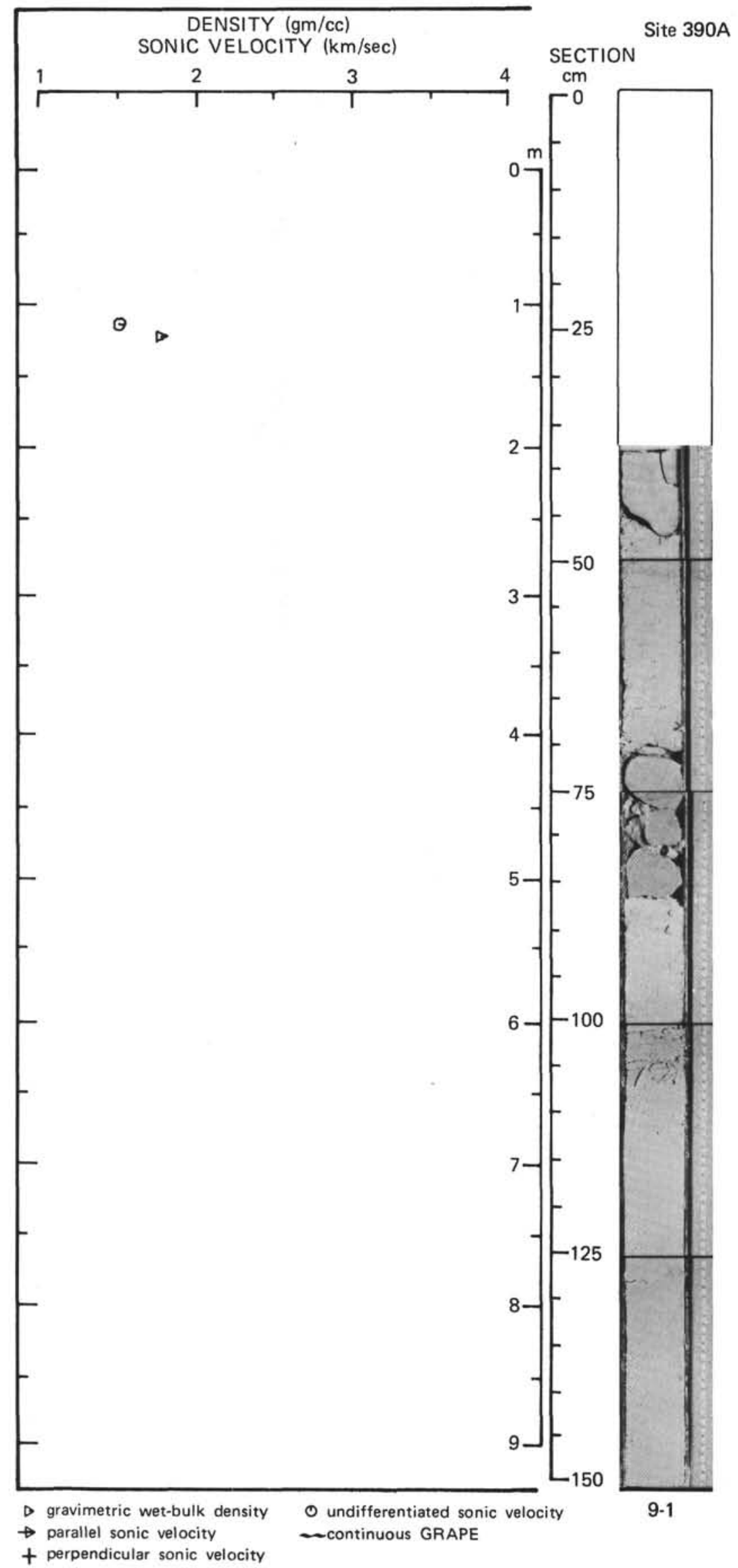




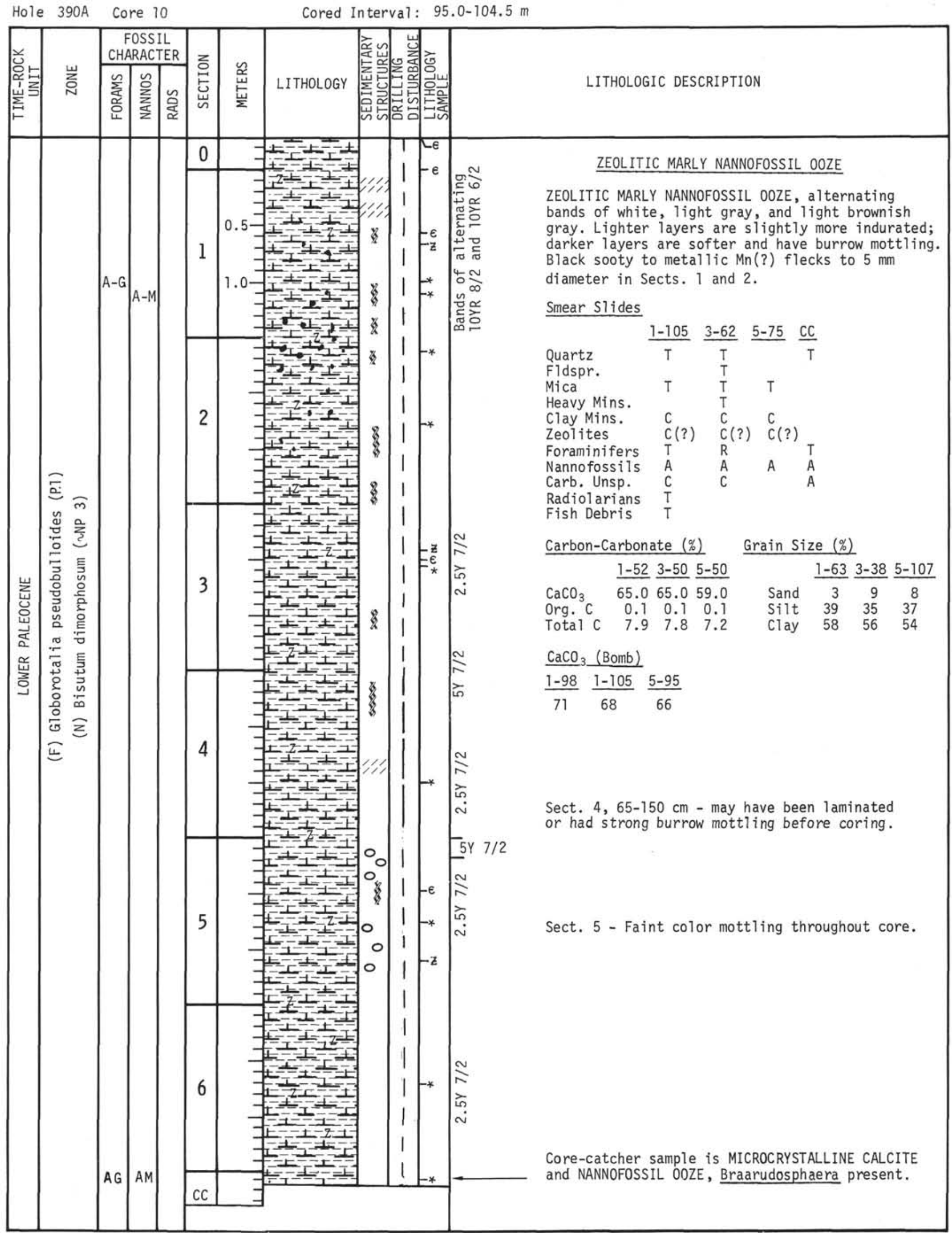




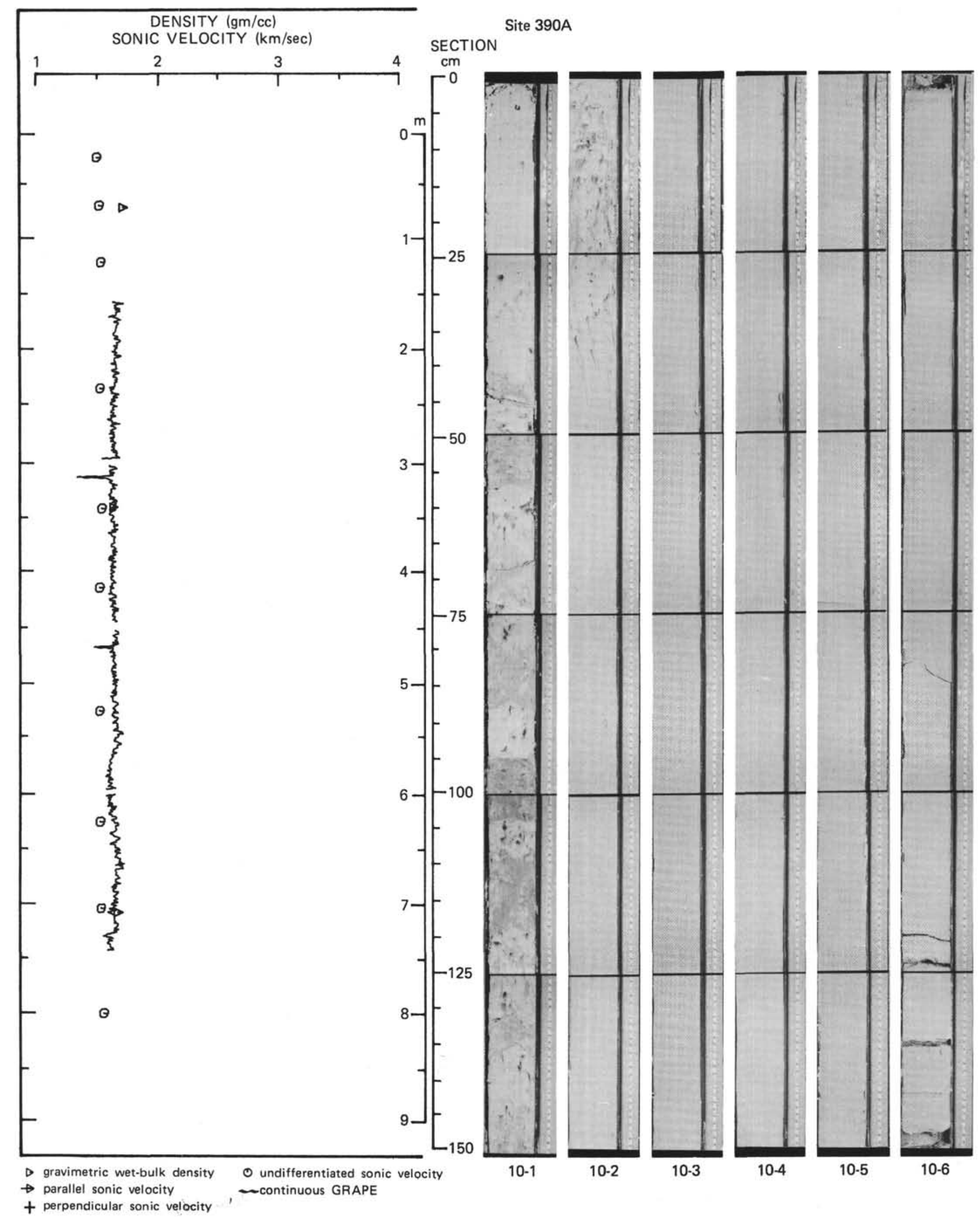




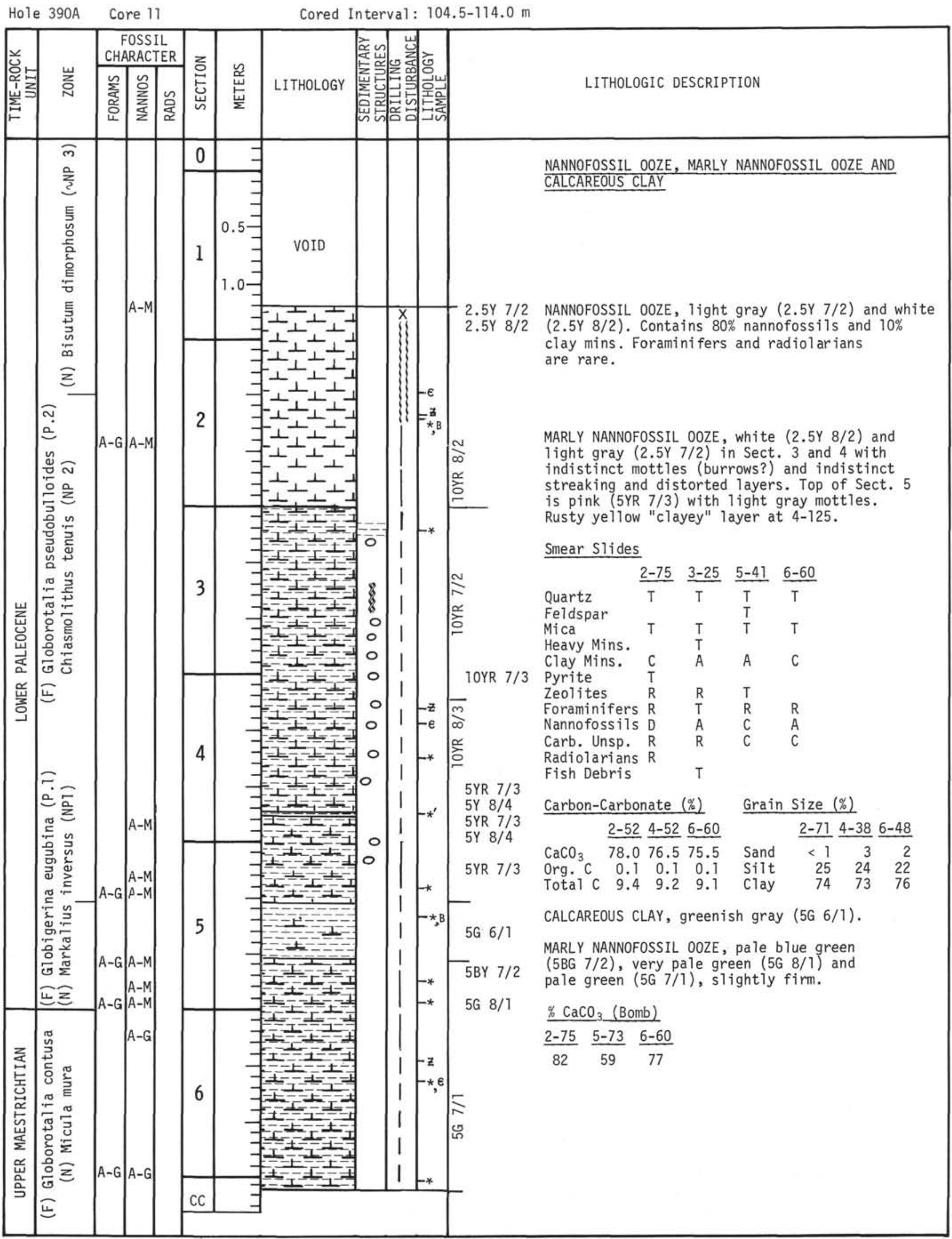




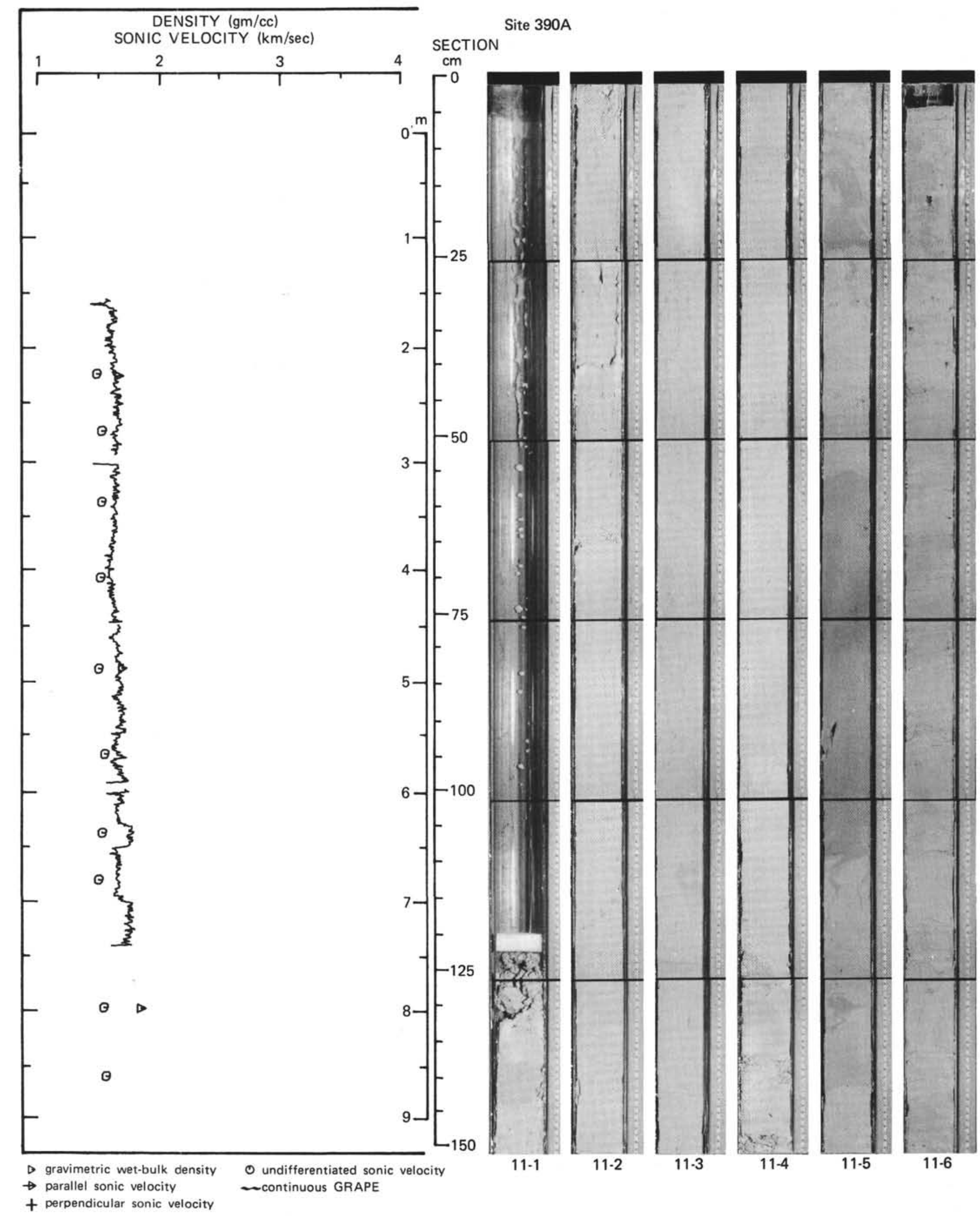




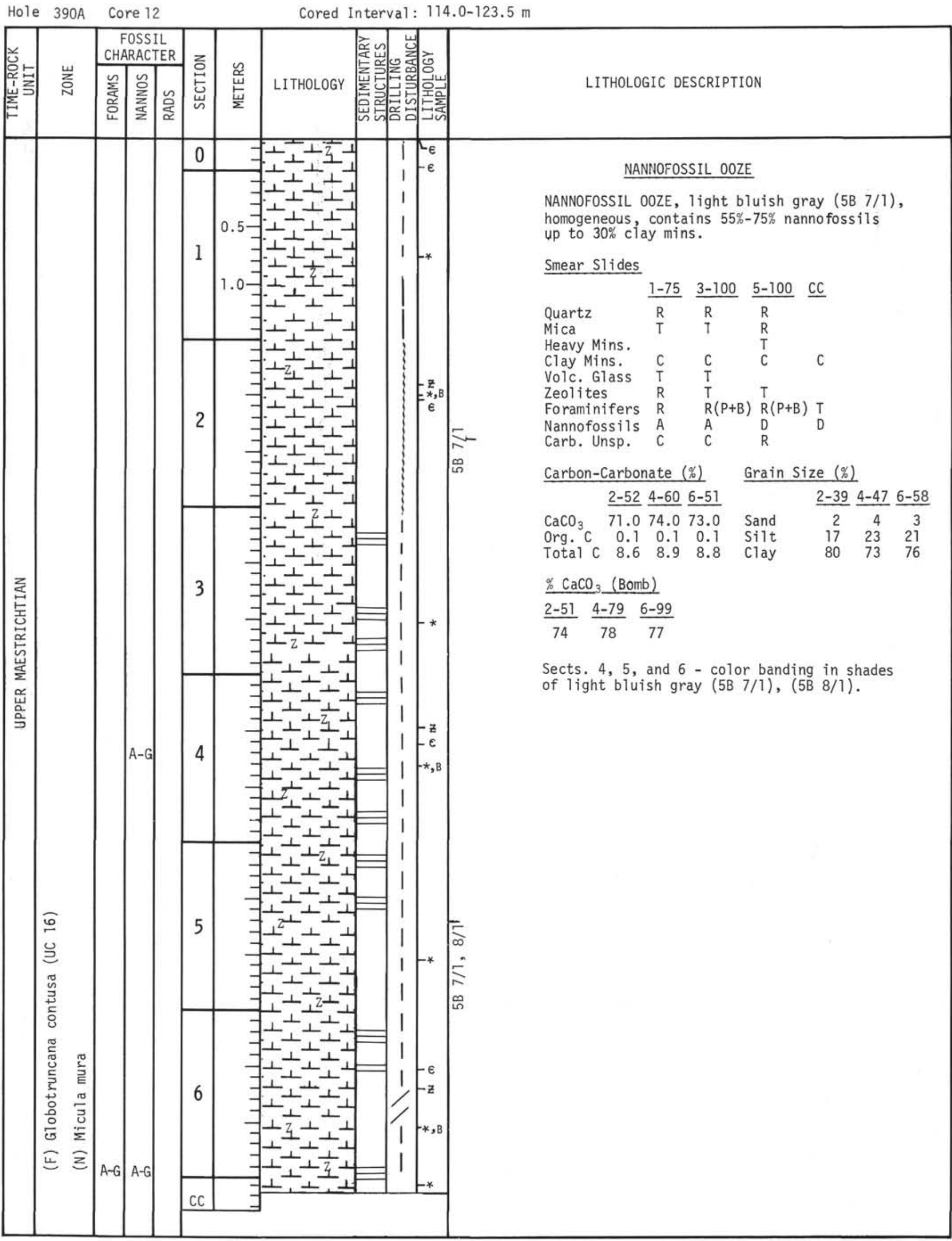




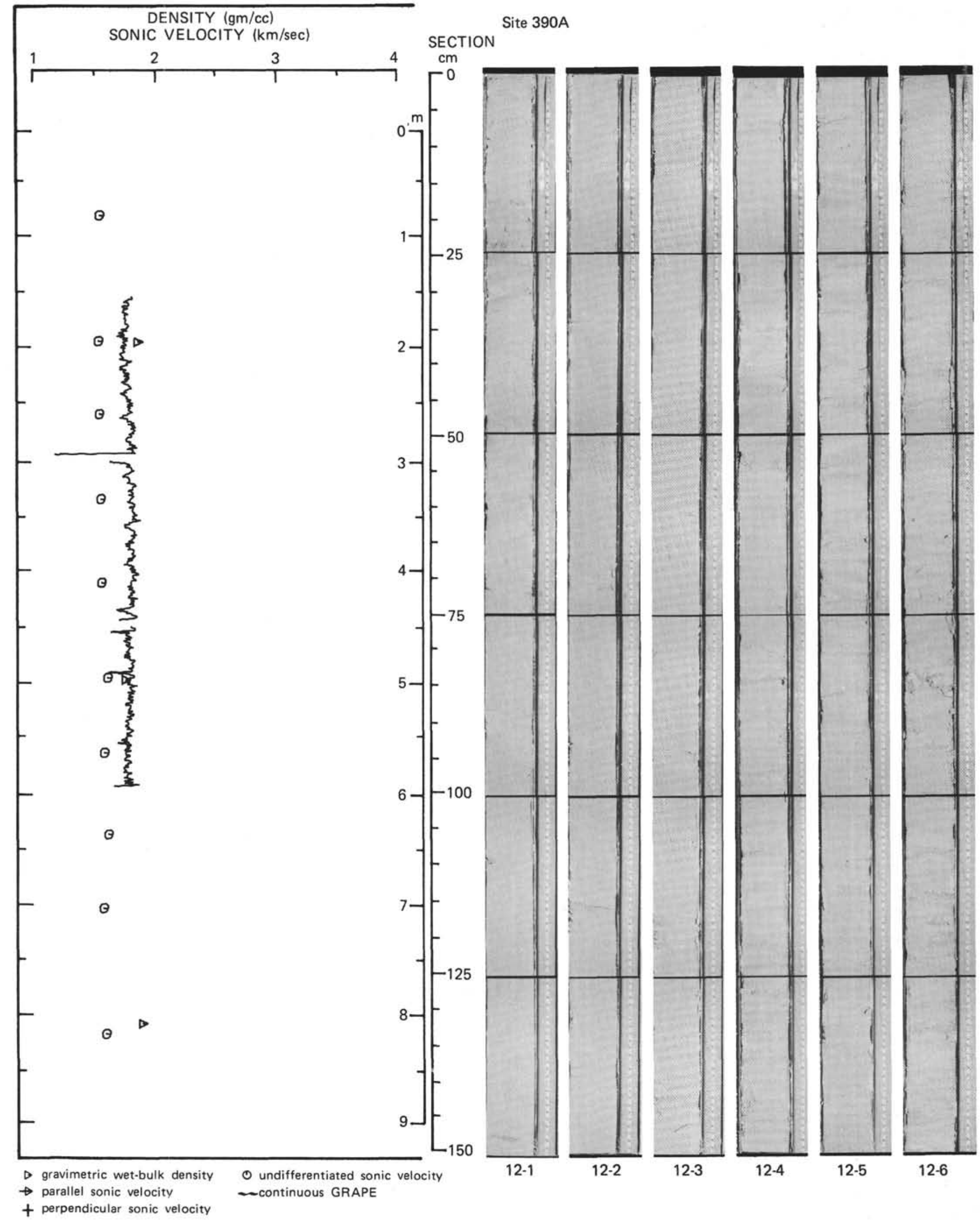




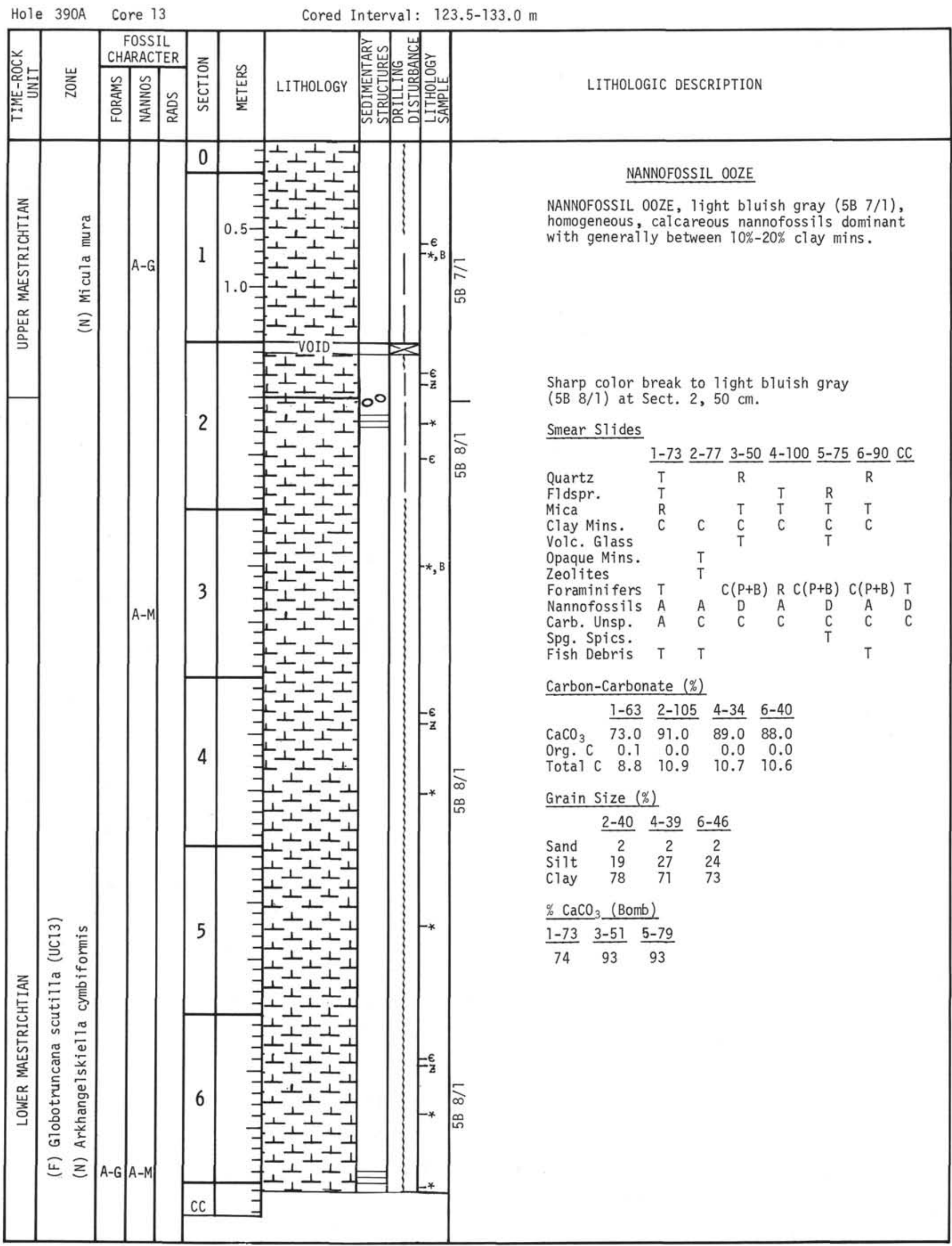




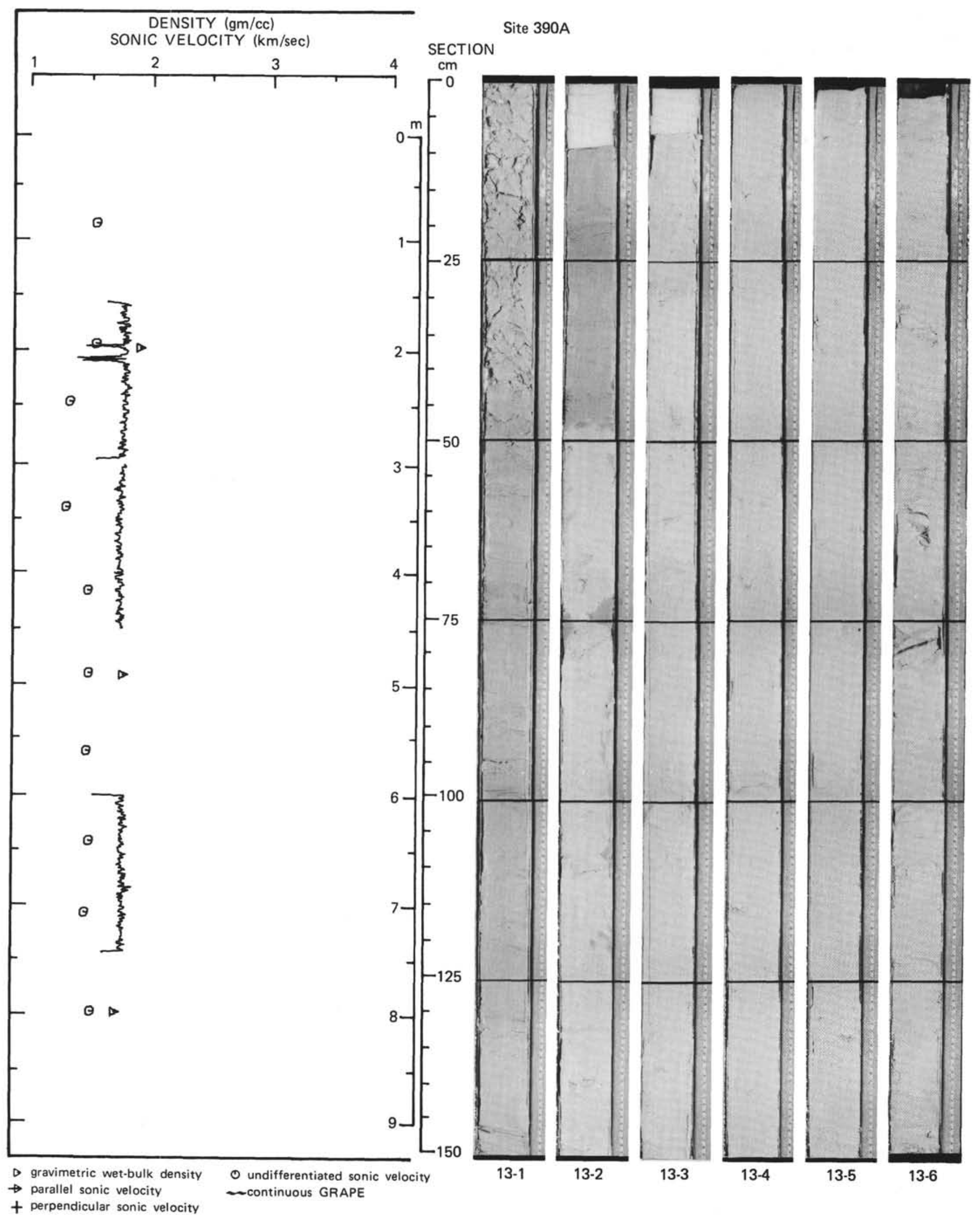




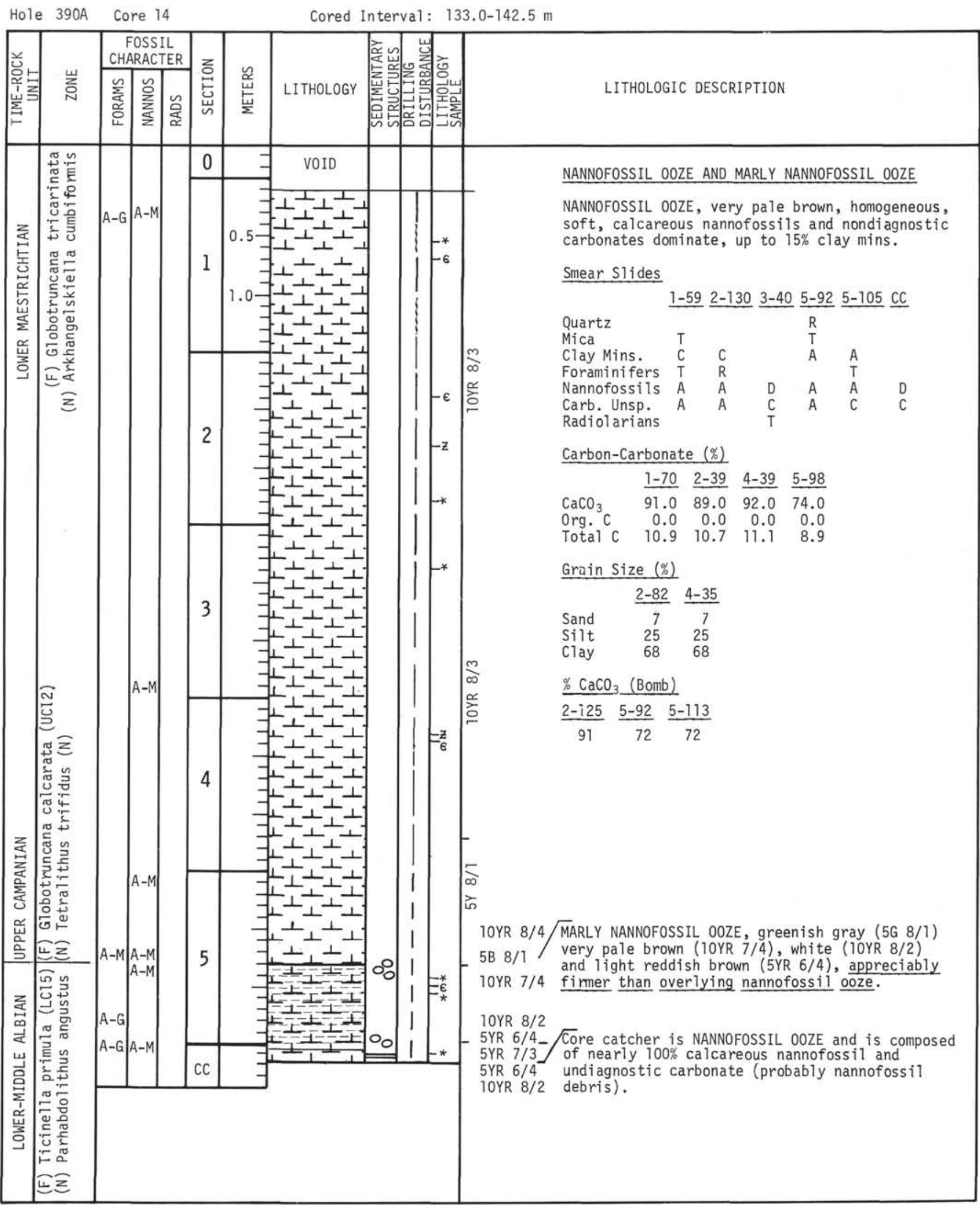




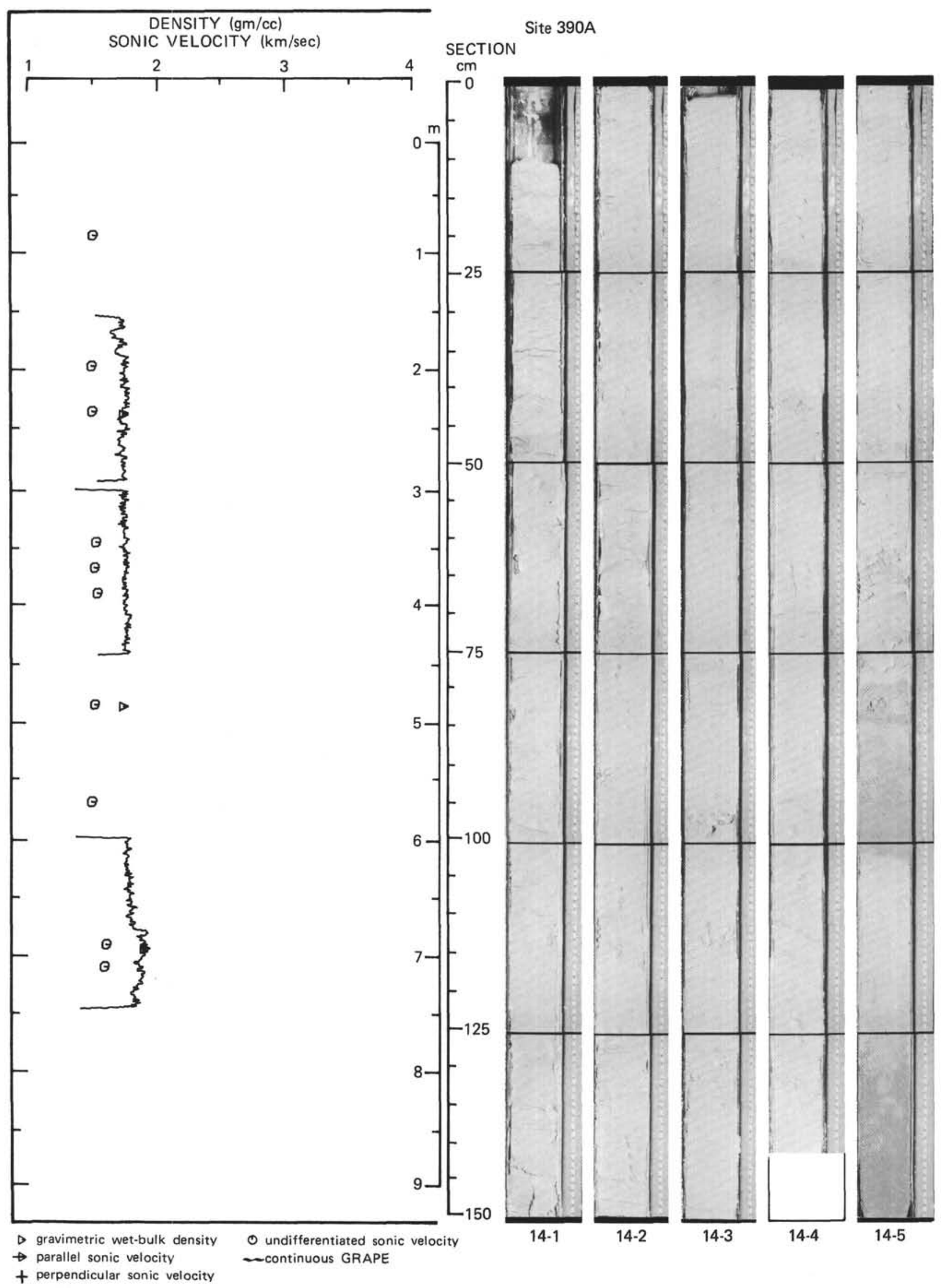

